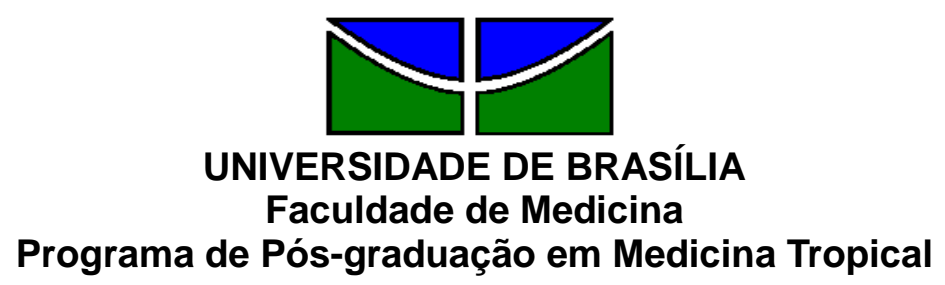

Rebecca Martins Cardoso

DETECÇÃO MOLECULAR DE ESPÉCIES DE LEISHMANIA EM MAMÍFEROS DE UNIDADES DE CONSERVAÇÃO E ENTORNO DO DISTRITO FEDERAL, BRASIL 


\title{
DETECÇÃO MOLECULAR DE ESPÉCIES DE LEISHMANIA EM MAMÍFEROS DE UNIDADES DE CONSERVAÇÃO E ENTORNO DO DISTRITO FEDERAL, BRASIL
}

\author{
Rebecca Martins Cardoso
}

\begin{abstract}
Tese de Doutorado apresentada ao programa de Pós-Graduação em Medicina Tropical da Universidade de Brasília para a obtenção do título de doutora em Medicina Tropical, na área de concentração: Epidemiologia e Controle das Doenças Infecciosas e Parasitárias.
\end{abstract}

Orientadora: Profa. Nadjar Nitz Silva Lociks de Araújo

Co-orientador: Prof. Rodrigo Gurgel Gonçalves

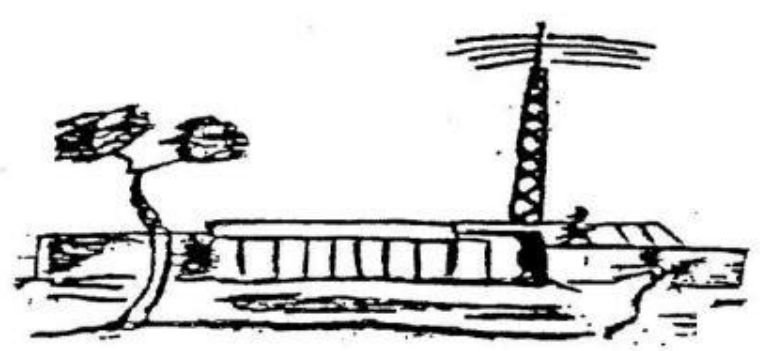

Brasília

2014 
Ficha catalográfica elaborada pela Biblioteca Central da Universidade de Brasília. Acervo 1020035.

Cardoso, Rebecca Martins.

C268d Detecção molecular de espécies de leistmania em mamíferos de unidades de conservação e entorno do Distrito Federal, Brasil / Rebecca Martins Cardoso. -- 2014.

115 f. : il. ; $30 \mathrm{~cm}$.

Tese (doutorado) - Universidade de Brasília, Programa de Pós-Graduação em Medicina Tropical, 2014.

Inclui bibliografia.

Orientação: Nadjar Nitz Lociks de Araújo ; Coorientação: Rodrigo Gurgel Gonçalves.

1. Leistmaniose. 2. Leistmania. 3. Mamífero - Distrito Federal (Brasil). I. Araujo, Nadjar Nitz Lociks de.

II. Gonçalves, Rodrigo Gurgel. III. Título.

CDU 616.993.161 


\title{
DETECÇÃO MOLECULAR DE ESPÉCIES DE LEISHMANIA EM MAMÍFEROS DE UNIDADES DE CONSERVAÇÃO E ENTORNO DO DISTRITO FEDERAL, BRASIL
}

\author{
UNIVERSIDADE DE BRASÍLIA
}

\section{BANCA EXAMINADORA}

Dra. Ana Maria Jansen - Membro titular

Laboratório de Biologia dos Tripanossomatídeos - Fiocruz - RJ

Dr. Jeffrey J. Shaw- Membro titular Universidade de São Paulo

Dr. Rafael Veríssimo Monteiro - Membro titular Universidade de Brasília

Dr. Vicente de Paulo Martins - Membro titular Universidade de Brasília

Dra. Nadjar Nitz Silva Lociks de Araújo - Presidente Universidade de Brasília

Dr. Andrey José de Andrade - Membro suplente Universidade de Brasília

19 de dezembro de 2014 
"Por vezes sentimos que aquilo que fazemos não é senão uma gota de água no mar. Mas o mar seria menor se lhe faltasse uma gota" (Madre Teresa de Calcutá). 
Dedico este trabalho à minha mãe Fada, em memória, e às minhas avós Moema, em memória, e Olga, por serem os anjos de luz na minha vida. 


\section{AGRADECIMENTOS}

Agradeço a todos que de alguma forma contribuíram para a realização deste trabalho:

Ao professor Gustavo Adolfo Sierra Romero, por ter acreditado no meu potencial, por ter me recebido de braços abertos no programa e por ter iniciado a minha orientação, assim como por todos os ensinamentos e apoio durante este trajeto.

À minha orientadora Nadjar Nitz Silva Lociks de Araújo, pela confiança em mim depositada, pelo incentivo constante, pelos valiosos ensinamentos na área molecular e por ser essa pessoa tão doce e amável.

Ao professor Rodrigo Gurgel Gonçalves, que para minha sorte, foi mais que um co-orientador, trabalhando incansavelmente para o êxito deste trabalho, colaborando e apoiando em todos os momentos do estudo.

Aos membros da banca pela gentileza de terem aceitado participar da discussão da minha defesa de tese.

Aos amigos e parceiros Marcelo Lima Reis, Jônatas Barbosa Cavalcante Ferreira, José Barbosa Bezerra, Nárjara Veras Grossmann e Marina Motta de Carvalho, pelo suporte fundamental durante todo trabalho de campo.

Aos que me ajudaram nas análises laboratoriais: os estagiários Júnio Donizette Mendes, Tauana de Souza Ferreira, Ana Gabriela de Oliveira Dietrich e Camilla Bernardes, a técnica Renata Ribeiro de Sousa, do laboratório de leishmanioses do NMT, e, em especial, à amiga Thaís Tâmara Castro Minuzzi Souza, por ter sido uma peça chave na realização dos experimentos.

A todos os funcionários do NMT/UnB que acompanharam minha rotina e foram sempre tão gentis. 
A todos os alunos e professores do Laboratório Multidisciplinar de Pesquisa em Doença de Chagas da Faculdade de Medicina da UnB, em especial à Mariana, à Tamires, à Marcelle e à Aline, por terem ajudado em diversos momentos do estudo.

Ao professor Rafael Veríssimo Monteiro por ter me proporcionado a oportunidade de acompanha-lo em campo, onde pude aprender bastante com sua experiência.

Aos técnicos e veterinários da DIVAL que se envolveram direta e indiretamente neste trabalho, pela receptividade e colaboração, em especial, ao Laurício Monteiro Cruz, à Maria Isabel Rao Bofill e à Gabriela Toledo.

Aos meus pais Rosângela e Danilo Cardoso por terem priorizado o estudo em minha vida e me ensinado que a verdadeira liberdade está no conhecimento.

E por fim, agradeço ao amor da minha vida, Marlos Mendonça, por ter trilhado comigo esse caminho, cheio de subidas e descidas, com toda paciência, compreensão, colaboração, incentivo e carinho. 


\section{LISTA DE FIGURAS}

Figura 1. Distribuição geográfica da leishmaniose tegumentar - LT (A) e da leishmaniose visceral - LV (B) no mundo, 2012. Fonte: WHO. Mapa: NTD/WHO 233

Figura 2. Eco-epidemiologia da leishmaniose visceral no norte do Brasil. Fonte: Lainson \& Rangel (2005). 355

Figura 3. Reserva Biológica da Contagem e Parque Nacional de Brasília, com indicação dos pontos de amostragem 488

Figura 4. Áreas amostrais no entorno das unidades de conservação estudadas no Distrito Federal. 499

Figura 5. Armadilhas de contenção viva "live trap", de arame tipo gaiola (a) e de alumínio tipo Sherman (b). 51

Figura 6. Grade montada na Reserva Biológica da Contagem. 522

Figura 7.Grade montada na mata de galeria do Parque Nacional de Brasília. 522

Figura 8. Grade montada no campo de murundu do Parque Nacional de Brasília. 533

Figura 9. Coleta de material biológico e marcação dos pequenos mamíferos no campo. 555

Figura 10. Fluxo do processamento das amostras biológicas dos cães e dos mamíferos silvestres. 577

Figura 11. Espécies de roedores pertencentes à família Cricetidae e subfamília Sigmodontinae: (A) Calomys sp., (B) Thalpomys lasiotis, (C) Necromys lasiurus, (D) Cerradomys scotti, (E) Oecomys bicolor e (F) Oecomys catherinae. 722

Figura 12. Espécies de roedores pertencentes à família Cricetidae e subfamília Sigmodontinae: (A) Nectomys rattus e (B) Rhipidomys macrurus; marsupiais da família Didelphidae (C) Gracilinanus agilis e (D) Didelphis albiventris; (E) Clyomys laticeps, roedor pertencente à família Echimyidae; e (F) Nasua nasua, carnívoro da 
família Procyonidae.

Figura 13. Gel de poliacrilamida a $6 \%$ mostrando resultado da PCR direcionada ao gene 24S $\alpha$ rRNA, com fragmento aproximado de $225 \mathrm{pb}$ sugestivo para Leishmania spp., de amostras de mamíferos silvestres.. 766

Figura 14. Gel de agarose a 1,3\% mostrando resultado da PCR direcionada ao ITS1, com as amostras de mamíferos silvestres $n^{\circ S} 03$ e 437 apresentando fragmento de aproximadamente $310 \mathrm{pb}$, sugestivo para Leishmania spp., e as amostras $n^{\circ 5} 415$ e 416 apresentando fragmento de aproximadamente $500 \mathrm{pb}$, sugestivo para outros tripanossomatídeos. 766

Figura 15. Gel de poliacrilamida a $6 \%$ mostrando resultado da PCR direcionada para a região conservada de kDNA (120pb) . 80

Figura 16. Gel de poliacrilamida a $6 \%$ mostrando resultado da PCR (A) direcionada ao gene 24Sa rRNA, com fragmento aproximado de $225 \mathrm{pb}$ sugestivo para Leishmania spp., das amostras caninas 1 a 19, e (B) ao ITS1, como fragmento de aproximadamente $310 \mathrm{pb}$, das amostras caninas que apresentaram bandas com os iniciadores D75 e D76. ..... 80

Figura 17. Identificação de DNA de Leishmania infantum em amostra de cão.

A) Sequência amplificada na PCR-ITS com 314 pb utilizando o animal 7. Os primers estão sublinhados. B) Gráfico produzido pelo algorítmo BLASTn durante a busca feita no GenBank. C) Alinhamento mostrando $100 \%$ de identidade com sequência de Leishmania infantum do locus KC347301. 844

Figura 18. Identificação de DNA de Leishmania amazonensis em amostra de Necromys lasiurus. A) Sequência amplificada na PCR-ITS com $331 \mathrm{pb}$ utilizando amostra do animal 3. Os primers estão sublinhados. B) Gráfico produzido pelo algorítmo BLASTn durante a busca feita no GenBank. C) Alinhamento mostrando $100 \%$ de identidade com sequência de Leishmania amazonensis do locus FJ753373. 855 


\section{LISTA DE TABELAS}

Tabela 1. Mamíferos infectados por diferentes espécies de Leishmania nas Américas. Revisado por Roque \& Jansen 2014 ................................ 29

Tabela 2. Mamíferos silvestres capturados na Reserva Biológica da Contagem e no Parque Nacional de Brasília entre novembro de 2011 e julho de 2012.

Tabela 3. Número de amostras positivas e proporção de mamíferos positivos para o gene 24Sa rRNA de tripanossomatídeos e para o (ITS) 1 de Leishmania spp., por espécie e em cada unidade de conservação.... 777

Tabela 4. Número de amostras de pele e de sangue positivas para o gene 24Sa rRNA apresentando fragmento de $\sim 225 \mathrm{pb}$, sugestivo para Leishmania spp., e para o ITS1, apresentando fragmento de $\sim 330 \mathrm{pb}$, por espécie e em cada unidade de conservação. 788

Tabela 5. Características dos cães amostrados residentes em área endêmica de leishmaniose visceral e tegumentar e resultados da infecção por Leishmania spp. Brasília, Distrito Federal, 2013. 799

Tabela 6. Identificação dos indivíduos com informações sobre a espécie, local de captura, tipo de amostra biológica, PCR utilizada, resultado do Blastn, Score, e-value e identidade de cada sequenciamento. 833 


\section{ABREVIATURAS E SIGLAS}

CAPES

CEUA

$\mathrm{CNPq}$

DF

DIVAL

DNA

dNTPs

EDTA

ELISA

FIOCRUZ

hsp

ITS

kDNA

LMPDC

LT

LTA

LV

LVC

NMT

NTD

OMS/WHO

OPAS

$\mathrm{pb}$
Coordenação de Aperfeiçoamento de Pessoal de Nível Superior

Comitê de Ética no Uso Animal

Centro Nacional de Desenvolvimento Científico e Tecnológico

Distrito Federal

Diretoria de Vigilância Ambiental

Deoxyribonucleic acid (ácido desoxirribonucléico)

deoxyribonucleotide triphosphates

(desoxirribonucleotídeo trifosfato)

Ácido etilenodiaminotretracético

Ensaio Imunoenzimático

Fundação Oswaldo Cruz

heat shock proteins (proteína de choque térmico)

Internal Transcribed Spacer (região

espaçadora transcrita interna)

kinetoplast DNA (DNA do cinetoplasto)

Laboratório Multidisciplinar de Pesquisa em Doença de Chagas

Leishmaniose Tegumentar

Leishmaniose Tegumentar Americana

Leishmaniose Visceral

Leishmaniose Visceral Canina

Núcleo de Medicina Tropical

Neglected Tropical Diseases (doenças tropicais

negligenciadas)

Organização Mundial de Saúde/ World Health

Organization

Organização Pan-Americana da Saúde

pares de bases 


$\begin{array}{ll}\text { PCR } & \begin{array}{l}\text { Polymerase Chain Reaction (reação em cadeia da } \\ \text { polimerase) }\end{array} \\ \text { PBS } & \begin{array}{l}\text { Phosphate-buffered saline (solução salina tamponada } \\ \text { com fosfato) }\end{array} \\ \text { PNB } & \begin{array}{l}\text { Parque Nacional de Brasília } \\ \text { Rebio }\end{array} \\ \text { RIFI } & \text { Reserva Biológica da Contagem } \\ \text { Taq } & \text { Reação de Imunofluorescência Indireta } \\ \text { TR DPP } & \text { Thermus aquaticus } \\ \text { UF } & \text { Unidade da Federação } \\ \text { UnB } & \text { Universidade de Brasília }\end{array}$




\section{FINANCIAMENTO}

O estudo foi financiado pelo CNPq (bolsa 141.151/2010-2), pela CAPES (processo n¹276/11, edital Parasitologia Básica) e pelo Programa de Pósgraduação em Medicina Tropical da Universidade de Brasília. 


\section{Sumário}

1. INTRODUÇÃO

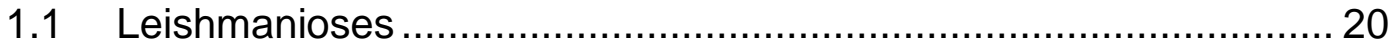

1.2 Situação epidemiológica das leishmanioses ................................... 20

1.3 Agentes etiológicos das leishmanioses.......................................... 25

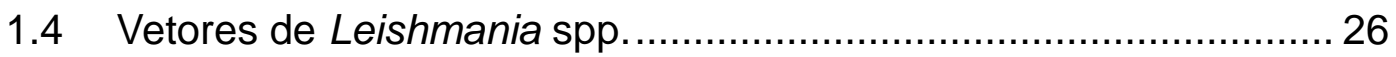

1.5 Hospedeiros e reservatórios de Leishmania spp. .......................... 27

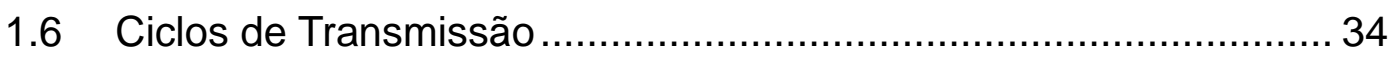

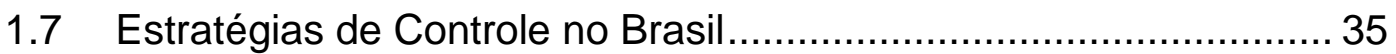

1.8 Diagnóstico laboratorial de Leishmania spp.................................. 37

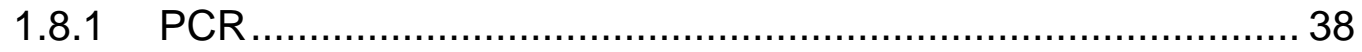

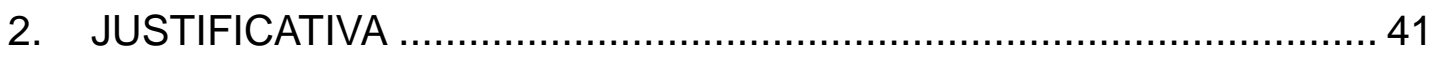

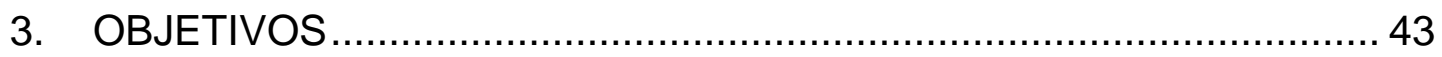

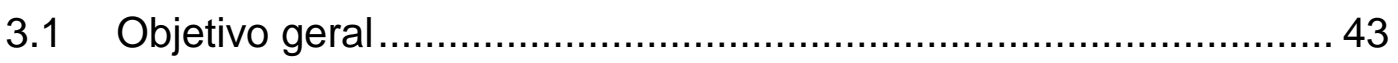

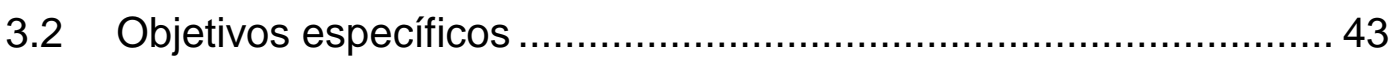

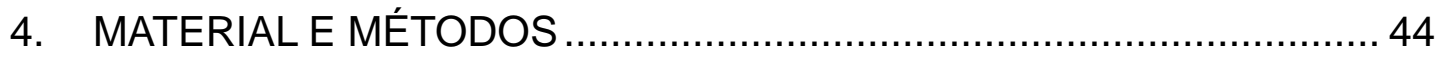

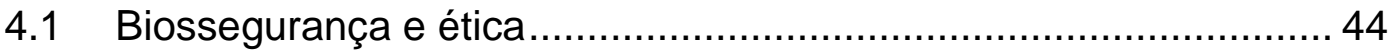

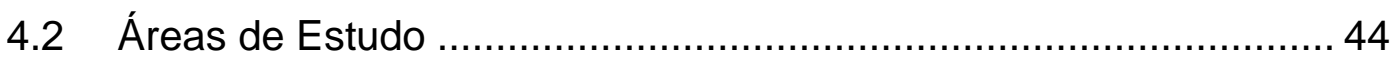

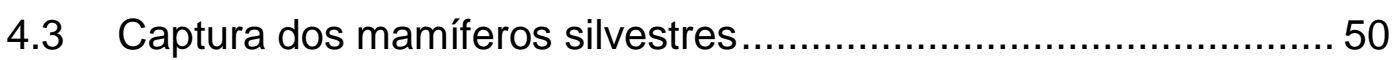

4.4 Contenção dos mamíferos silvestres ............................................ 54

4.5 População e amostragem dos cães domésticos ............................ 55

4.6 Coleta e processamento do material biológico .............................. 56

4.6.1 Ensaio imunoenzimático (ELISA) e Reação de Imunofluorescência

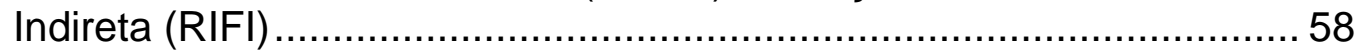

4.6.2 Teste imunocromatográfico rápido de duplo percurso - TR DPP

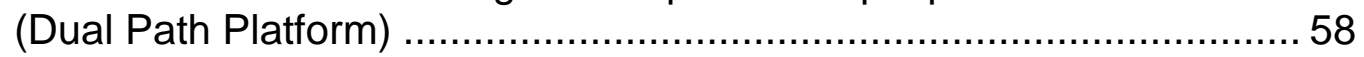

4.6.3 Detecção de DNA de Leishmania sp. a partir de amostras biológicas......

4.6.3.1 Extração do DNA das amostras de pele de pequenos mamíferos

4.6.3.2 Extração do DNA das amostras de sangue dos pequenos

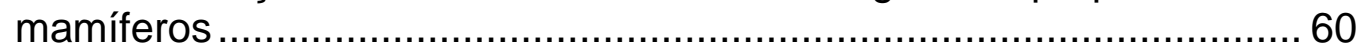

4.6.3.3 Extração do DNA do plasma dos cães....................................... 61

4.6.3.4 Reação em cadeia da polimerase (PCR) ................................. 62

4.6.3.5 Controle endógeno da PCR - $\beta$-actina ...................................... 62 
4.6.3.6 PCR dirigida ao kDNA de Leishmania spp................................ 63

4.6.3.7 PCR dirigida ao gene 24Sa rRNA de tripanossomatídeos ........ 65

4.6.3.8 PCR dirigida à região espaçadora interna do DNA ribossômico ITS1 de Leishmania spp.

4.6.3.9 Preparação dos produtos da PCR para sequenciamento ......... 68

4.6.3.10 Sequenciamento e análise das sequências ............................ 68

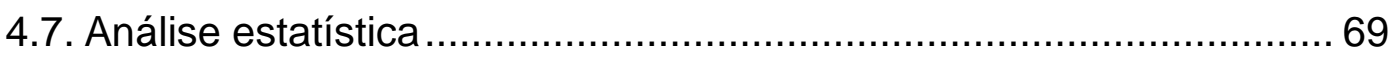

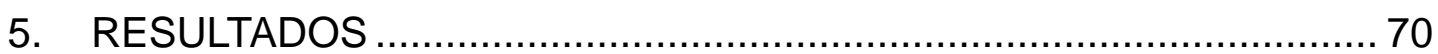

5.1 Riqueza e abundância de mamíferos silvestres no PNB e REBIO 70

5.2 Detecção molecular de Leishmania spp. nos mamíferos silvestres 74

5.3 Detecção molecular de Leishmania spp. nos cães domésticos ...... 78

5.4 Detecção de outros tripanossomatideos nas amostras................... 81

5.5 Identificação específica das amostras ............................................ 81

6 DISCUSSÃO

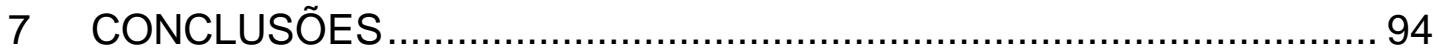

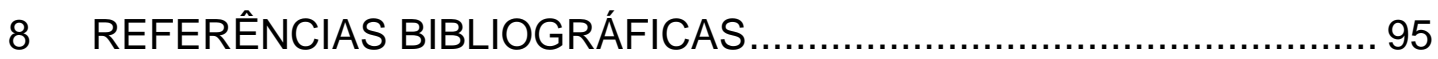

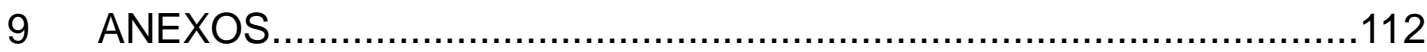




\section{RESUMO}

Mamíferos silvestres, sinantrópicos e domésticos podem ser hospedeiros de diferentes espécies de Leishmania. Estudos sobre possíveis reservatórios de Leishmania em diferentes áreas são fundamentais para a definição das estratégias de vigilância e controle das doenças. No presente estudo, avaliou-se a ocorrência de infecção por Leishmania spp. em mamíferos de duas unidades de conservação e entorno do DF, Brasília, Brasil. Pequenos mamíferos foram capturados em 2011 e 2012 em duas Unidades de Conservação Federais do DF, o Parque Nacional de Brasília (PNB) e a Reserva Biológica da Contagem (Rebio), e, em 2013, foram amostrados cães de condomínios residenciais e núcleos rurais do entorno das unidades. Amostras de pele e sangue dos animais silvestres e dos cães foram avaliadas por meio de diferentes testes moleculares, direcionados à região polimórfica D7 do gene 24Sa rRNA, para a região conservada do minicírculo de kDNA e para a região espaçadora interna do DNA ribossômico ITS1 de Leishmania spp. As espécies de Leishmania foram identificadas mediante o sequenciamento dos produtos amplificados. As amostras de sangue dos cães foram submetidas ao teste imunocromogrático rápido (DPP) para detecção de anticorpos anti-Leishmania. Foram estudados 179 mamíferos silvestres, os quais $20,1 \%$ tiveram amostras positivas para Leishmania spp. nos testes moleculares (Clyomys laticeps, Gracilinanus agilis, Necromys lasiurus, Nectomys rattus, Rhipidomys macrurus e Didelphis albiventris). Não foram observadas diferenças significativas comparando a proporção de indivíduos infectados por Leishmania spp. entre as duas áreas amostradas e entre as espécies. A maioria das amostras positivas era do roedor $N$. lasiurus, as quais foram identificadas como $L$. amazonensis ou $L$. braziliensis. As 19 amostras dos cães estudados foram positivas ao teste DPP, porém, apenas cinco $(26,3 \%)$ foram positivas para Leishmania spp. nas análises moleculares. As amostras de cães foram identificadas como $L$. infantum. Os resultados sugerem o envolvimento de seis espécies de 
mamíferos silvestres na transmissão enzoótica de Leishmania spp. no Distrito Federal, sendo o primeiro registro de $L$. amazonensis no roedor silvestre N. lasiurus no Brasil Central.

Palavras chaves: Leishmania, Eco-epidemiologia, Mamíferos, Hospedeiros, Diagnóstico molecular, PCR.

\begin{abstract}
Wild, synanthropic and domestic mammals are hosts of Leishmania spp. Studies on possible reservoirs of Leishmania in different areas are fundamental for the development of strategies for the surveillance and control of this disease. In the present study, we evaluated the Leishmania spp. occurrence in mammals in two conservation units and their surroundings in Brasilia, Federal District (FD) Brazil. Small mammals were captured in 2011 and 2012 in two conservation units of FD, the Brasília Nacional Park (BNP) and the Biological Reserve of Contagem (BRC). In 2013, we took samples from dogs in residential areas in the surroundings of these conservation units. Skin and blood samples were evaluated by PCR using different molecular markers (D7 24Sa rRNA, kDNA and DNA ITS1). The Leishmania species were identified by sequencing. Blood samples from the dogs were also subjected to the rapid imunocromogratical test (DPP) for detection of anti-Leishmania antibodies. 179 wild mammals were studied, of which $20.1 \%$ had DNA of Leishmania spp successfully detected in at least one positive sample. Six species were considered infected: Clyomys laticeps, Gracilinanus agilis, Necromys lasiurus, Nectomys rattus, Didelphis albiventris and Rhipidomys macrurus. No significant differences comparing the proportion of individuals infected with Leishmania spp were observed between the two sampled areas and between wild mammal species. Most of the positive samples were collected from the rodent $N$. lasiurus, infected by
\end{abstract}


L. amazonensis or L. braziliensis. All 19 dog samples studied were positive by DPP, however, only five (26.3\%) were positive for Leishmania spp. by PCR. DNA sequence of ITS1 amplicons from dog samples had $100 \%$ identity with $L$. infantum sequence. The results suggest the involvement of six species of wild mammals in the enzootic transmission of Leishmania spp. in FD. This is the first record of $L$. amazonensis in N. lasiurus in Central Brazil.

Keywords: Leishmania, Eco-epidemiology, Mammals, Hosts, Molecular diagnostics, PCR. 


\section{INTRODUÇÃO}

\section{$1.1 \quad$ Leishmanioses}

As leishmanioses são zoonoses, que acometem os animais silvestres, os animais domésticos e o homem, apresentando ampla ocorrência mundial. Representam um grupo de doenças com diferentes características clínicas e epidemiológicas, causadas por 18 espécies de protozoários do gênero Leishmania (Ready 2013) e que são transmitidas aos humanos pela picada de insetos vulgarmente conhecidos como flebotomíneos, constituindo um grave problema de saúde pública no Brasil e no mundo. As leishmanioses se manifestam de quatro formas diferentes: i) visceral, também conhecida como calazar, a forma mais grave da doença; ii) cutânea, a mais comum; iii) mucocutânea; e iv) cutânea difusa. A Leishmaniose Visceral (LV) é uma doença crônica sistêmica, que afeta os órgãos como o fígado e o baço. A Leishmaniose Tegumentar (LT) inclui as formas cutânea, cutânea difusa e mucocutânea, caracterizadas pela formação de úlceras na pele (Brasil 2006, 2010). Existem também as infecções assintomáticas e autoresolutivas.

\subsection{Situação epidemiológica das leishmanioses}

De acordo com a Organização Mundial da Saúde (WHO 2014a) as leishmanioses afetam principalmente pessoas de baixa renda na África, Ásia e América Latina, e estão associadas à pobreza e ao deslocamento da população para áreas com ciclos de transmissão existentes, sendo considerada uma Doença Tropical Negligenciada. A subnutrição, com dietas pobres em proteínas, ferro, vitamina $A$ e zinco, pode comprometer a imunidade dos indivíduos, aumentando o risco de uma infecção evoluir para 
a doença. As condições sanitárias domésticas precárias, por exemplo, falta de gestão de resíduos e esgoto a céu aberto, podem aumentar os locais de criação e repouso de flebotomíneos e, bem como, o seu acesso aos seres humanos. A migração e a exposição ocupacional são fatores de risco importantes, uma vez que as pessoas ao se movimentarem ou se estabelecerem em áreas de florestas, ficam mais próximas do habitat de flebotomíneos (WHO 2014a). Tal fato tem mudado o perfil epidemiológico das doenças.

A expansão das leishmanioses também está ligada às mudanças ambientais, como desmatamento, construção de barragens, sistemas de irrigação e urbanização. Karagiannis-Voules et al. (2013) associaram a doença a fatores socioeconômicos e à precipitação. As leishmanioses são sensíveis ao clima, e fortemente afetadas por mudanças na precipitação, temperatura e umidade, que podem levar a fortes efeitos sobre vetores e os hospedeiros reservatórios, alterando sua distribuição e influenciando na sua sobrevivência e nos tamanhos das populações. Pequenas flutuações na temperatura podem ter um efeito profundo sobre o ciclo de desenvolvimento de promastigotas de Leishmania em flebotomíneos, permitindo a transmissão do parasito em áreas anteriormente não endêmicas para as doenças. Seca, fome e inundações resultantes das alterações climáticas podem levar ao deslocamento em massa e a migração de pessoas para áreas com transmissão de leishmanioses (WHO 2014a).

A OMS estima que mais de 350 milhões de pessoas estejam expostas ao risco da infecção por Leishmania spp., com registro aproximado de 1,3 milhões de casos novos das diferentes formas clínicas ao ano. Um estudo realizado por Alvar et al. (2012) mostrou que um total de 98 países e 3 territórios, distribuídos em 4 continentes (Américas, Europa, África e Ásia), registraram a transmissão endêmica de leishmanioses, com uma estimativa de que ocorrem a cada ano 0,2 a 0,4 milhões de casos de LV e 0,7 a 1,2 milhões de casos de LT. Além disso, entre 20.000 e 40.000 mortes são 
estimadas por ano. Atualmente, apenas cerca de 600.000 dos casos de leishmanioses estimados são registrados ao ano. Como a notificação é obrigatória em apenas um terço dos países afetados, o verdadeiro aumento de casos permanece desconhecido (Alvar et al. 2012, WHO 2014b).

Mais de $90 \%$ dos casos globais de LV ocorrem em apenas seis países: Índia, Bangladesh, Sudão, Sudão do Sul, Brasil e Etiópia (Figura 1b). No Brasil, aproximadamente 3500 casos humanos de LV foram registrados por ano entre 2003-2007, o que corresponde a $95 \%$ de todos os casos registrados nas Américas. A LT é mais amplamente distribuída, com aproximadamente um terço dos casos ocorrendo nas Américas, no Mediterrâneo e na Ásia ocidental, partindo do Oriente Médio até a Ásia Central (Figura 1a). Os 10 países com o maior número estimado de casos, Afeganistão, Argélia, Colômbia, Brasil, Irã, Síria, Etiópia, Sudão do Norte, Costa Rica e Peru, juntos, correspondem de 70 a $75 \%$ da incidência global estimada de LT. Quase $90 \%$ dos casos de leishmaniose mucocutânea ocorrem no Brasil, Peru e Bolívia (Alvar et al. 2012).

O aumento da distribuição geográgica das leishmanioses vem ocorrendo desde 1993 e tem havido um aumento do número de casos registrados. De acordo com Aagaard-Hansen et al. (2010), diferentes tipos de movimentos populacionais, destacando a urbanização e a migração laboral, desenvolvem um importante papel na propagação das leishmanioses, expondo as pessoas à transmissão. 

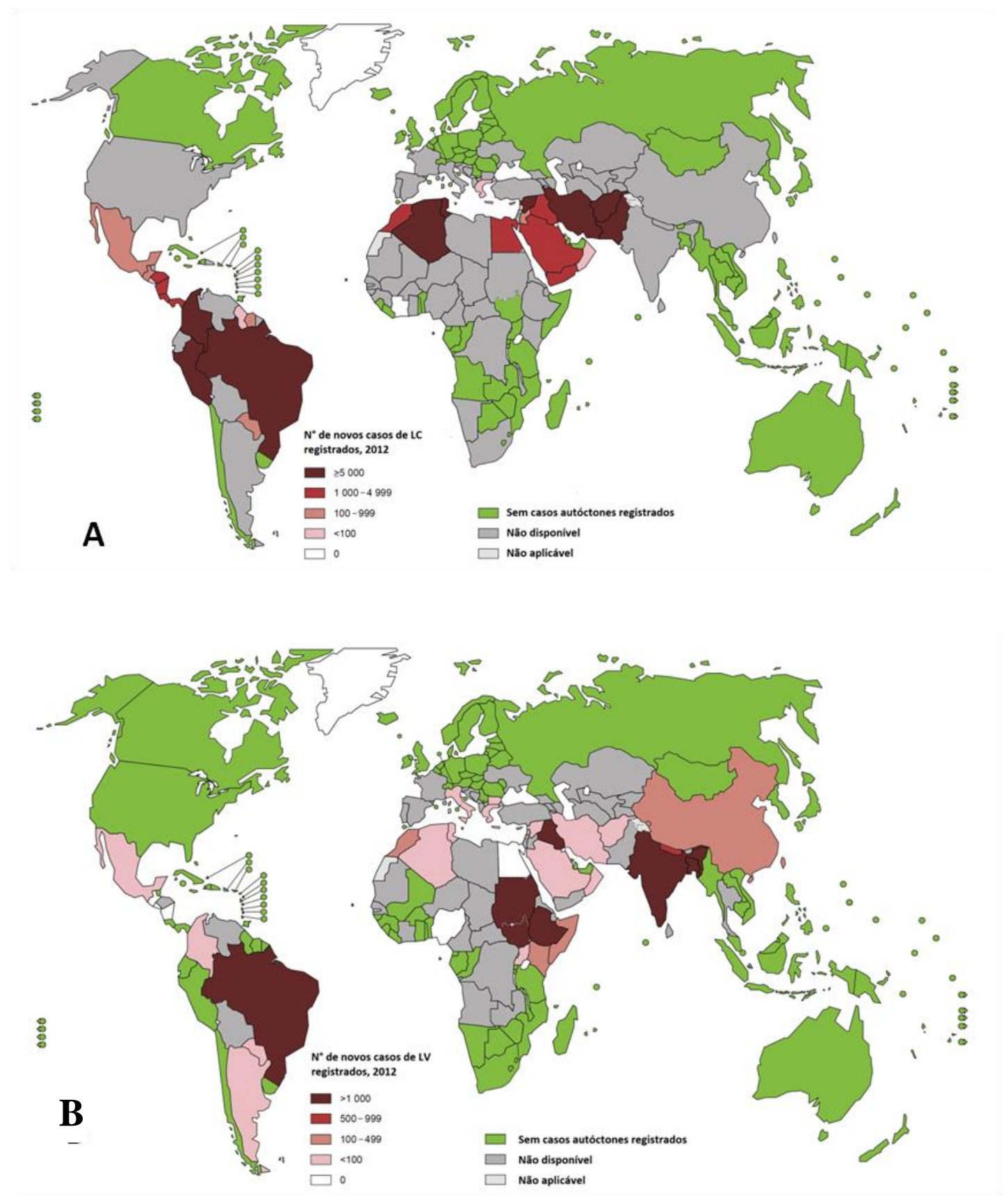

Figura 1. Distribuição geográfica da leishmaniose tegumentar - LT $(A)$ e da leishmaniose visceral - LV (B) no mundo, 2012. Fonte: WHO. Mapa: NTD/WHO 
De acordo com dados da Organização Pan-Americana da Saúde/Organização Mundial da Saúde (OPAS/OMS 2012), na região das Américas, os casos autóctones das leishmanioses em humanos foram registrados desde o sul dos Estados Unidos até o norte da Argentina, com exceção das ilhas do Caribe, Chile e Uruguai. Anualmente, uma média de 60.000 casos de Leishmaniose Tegumentar Americana (LTA) e 4.000 casos de LV são diagnosticados, com uma taxa de mortalidade de 7\%.

A LV está presente em 24 estados em todas as cinco regiões do Brasil, principalmente na periferia dos grandes centros urbanos. Epidemias foram registradas em 1980 e 1990. Em 1999 e 2000, cerca de 4.000 casos foram relatados a cada ano. Entre 2001 e 2010, ocorreram 33.633 casos e 2.279 mortes. O grupo mais afetado compreende crianças do sexo masculino com menos de 10 anos de idade que vivem no Nordeste do Brasil (OPAS/OMS 2012).

No Brasil o número de casos de LTA subiu de 6.335 em 1984 para 30.030 em 1996 (Brandão-Filho et al. 1999). Entre 1988 e 2009, houve uma média de 26.021 casos de LTA por ano no Brasil, com uma taxa de infecção de 14,1 casos por 100.000 habitantes (OPAS/OMS 2012). Depois de 2005, o número total de casos de LTA caiu e permaneceu estável, um pouco acima de 20.000 (Karagiannis-Voules et al. 2013).

Na década de 1980, a LTA foi assinalada em 19 Unidades da Federação (UF), verificando sua expansão geográfica quando, em 2003, foi confirmada a autoctonia em todos os estados brasileiros. A região Norte é responsável pelo maior número de casos e a maior taxa de infecção $(66,9$ casos por 100.000 habitantes). Em 2010, 22.397 casos de LTA foram registrados no país (OPAS/OMS 2012).

O primeiro registro da LV no Distrito Federal foi no ano de 2005, nos meses de agosto e outubro, em Sobradinho II, nas localidades da Fercal (Bananal) e Setor de Mansões no Condomínio Serra Azul. Nos últimos anos 
tem sido registrado um aumento nos casos de Leishmania infantum em cães domésticos na região norte do DF, que vem sofrendo com a urbanização descontrolada da sua área rural (Carranza-Tamayo et al. 2010).

Em um estudo conduzido por Carranza-Tamayo e colaboradores (2010) no DF, cães soropositivos da região de Sobradinho $(n=162)$, foram eutanasiados e em $24(15 \%)$ dos animais as culturas foram positivas para Leishmania, a partir da medula óssea, fígado, linfonodos, baço ou pele. Doze desses isolados foram identificados como $L$. infantum por eletroforese enzimática. Esta pesquisa demonstrou a presença de cães infectados em áreas onde foram confirmados casos de LV humana.

Nos últimos anos casos humanos de LTA e LV têm sido observados no DF (Sampaio et al. 2009; Carranza-Tamayo 2010); considerando somente os casos autóctones, entre 2007 e 2012, 24 casos humanos de LV e 36 de LTA foram registrados (SES/DF 2012). Em 2013 foram notificadas no Sistema de Informação de Agravos de Notificação - SINAN/NET, 98 pessoas com suspeita de LV e 47 casos foram confirmados. Desse total, 45 casos (96\%) eram importados de outras UFs e dois (4\%) autóctones, provenientes de Sobradinho e Lago Norte. Em relação à LTA, 26 casos foram confirmados, dois autóctones em Planaltina (SES/DF 2014).

\subsection{Agentes etiológicos das leishmanioses}

As leishmanioses são resultantes da infecção por protozoários do gênero Leishmania, pertencentes à família Trypanosomatidae, parasitos intracelulares obrigatórios das células do sistema fagocítico mononuclear. Esses parasitos possuem duas formas principais: uma flagelada ou promastigota, encontrada no tubo digestivo do inseto vetor, e outra aflagelada ou amastigota, observada nos tecidos dos hospedeiros vertebrados. 
A LT é causada por 18 espécies de Leishmania patogênicas para os seres humanos, sendo que nas Américas a infecção humana ocorre por 11 espécies (Ready, 2013) agrupadas nos subgêneros Leishmania e Viannia, onde as três espécies mais importantes do subgênero Leishmania são: $L$. mexicana, $L$. amazonensis e $L$. venezuelensis e do subgênero Viannia são: L. braziliensis, L. panamensis, L. peruviana e L. guyanensis. As espécies são morfologicamente indistinguíveis, mas podem ser diferenciadas por análise isoenzimática, análise da sequência do DNA, ou anticorpos monoclonais (PAHO 2014).

No Brasil já foram identificadas sete espécies responsáveis pela LTA, sendo seis do subgênero Viannia e uma do subgênero Leishmania. As três espécies mais encontradas são: $L$. braziliensis, $L$. guyanensis e $L$. amazonensis. As espécies L. lainsoni, L. naiffi, L. lindembergi e L. shawi foram identificadas mais recentemente em estados das regiões Norte e Nordeste (Brasil 2010). Nas Américas, a Leishmania infantum (syn. L. chagası) é a espécie envolvida na LV (Brasil 2006).

\subsection{Vetores de Leishmania spp.}

Os vetores das leishmanioses são insetos denominados flebotomíneos, pertencentes à Ordem Diptera, Família Psychodidae, Subfamília Phlebotominae, conhecidos popularmente, dependendo da localização geográfica, como mosquito palha, tatuquira, birigui, entre outros. Existem mais de 900 espécies de fletobomíneos descritas no mundo. Nas Américas, há cerca de 50 espécies de flebotomíneos envolvidas na transmissão (PAHO 2014). Até 2013, 267 espécies haviam sido registradas no Brasil e 19 são apontadas como vetores de importância médicoveterinária (Shimabukuro \& Galati 2010, Andrade et al. 2013).

No Brasil, as principais espécies envolvidas na transmissão da LTA 
são: Bichromomyia flaviscutellata, Nyssomyia whitmani, N. umbratilis, $N$. neivai, Psychodopygus wellcomei e Migonemyia migonei (Barbosa et al. 2008, Ready 2013, Diniz et al. 2014). Estas espécies de flebotomíneos foram definidas como potenciais vetores, de acordo com o Manual de Vigilância da Leishmaniose Tegumentar Americana do Ministério da Saúde, por atenderem aos critérios que atribuem a uma espécie a capacidade vetorial segundo Killick-Kendrick e Ward (1981) e Killick-Kendrick (1990). Cabe ressaltar que o papel vetorial de cada uma dessas espécies dependerá da espécie de Leishmania presente no intestino. Embora ainda não tenha sido comprovado o papel da Pintomyia fischeri como vetor primário da LTA, esta espécie tem sido encontrada infectada com frequência em ambientes domiciliares em áreas de transmissão da doença (Brasil 2010, Pita-Pereira et al. 2009, 2011).

O principal vetor da LV nas Américas é o flebotomíneo Lutzomyia longipalpis, espécie bem adaptada ao ambiente peridoméstico e com ampla distribuição geográfica (Brasil 2010), porém, Lu. cruzi aparece com vetor nos municípios de Corumbá e Ladário/MS, na fronteira entre Brasil e Bolívia (Dos Santos et al. 1998) e Lu. evansi é também um importante vetor na Colômbia e Venezuela (Lainson 2010). No DF são conhecidas cerca de 30 espécies de flebotomíneos (Carvalho et al. 2010, Ferreira et al. 2014). Dados ecológicos dessas espécies ainda são escassos e pouco se sabe sobre o papel vetorial delas na manutenção do ciclo silvestre de Leishmania spp. em matas de galeria e áreas de cerrado.

\subsection{Hospedeiros e reservatórios de Leishmania spp.}

A detecção de Leishmania spp. em uma espécie animal não é o suficiente para definir tal espécie de hospedeiro como reservatório do parasito. As populações de uma espécie têm sido tradicionalmente caracterizadas como reservatórios quando as mesmas mantêm um parasito 
e ainda permitem a sua transmissão para outras populações. Atualmente o reservatório vem sendo definido como um sistema ecológico, formado por uma espécie ou um conjunto de espécies responsáveis por manter a circulação de um parasito na natureza em um determinado período e espaço (Haydon et al. 2002, Ashford 2003, Roque \& Jansen 2014).

As diferentes espécies de Leishmania que causam LT e LV são encontradas em vários mamíferos silvestres, sinantrópicos e domésticos. Várias espécies de roedores, marsupiais, pilosos, cingulatos, morcegos, primatas e carnívoros silvestres foram registradas como hospedeiros naturais e potenciais reservatórios. Suínos e equinos também foram registrados como hospedeiros da Leishmania (Rolão et al. 2005, Brazil et al. 1987, Schubach et al. 2004, De Souza et al. 2005, Souza et al. 2009, Dahroug et al. 2010, Rougeron et al. 2011, Roque \& Jansen 2014), porém, seus papéis na manutenção do parasito no meio ambiente ainda não foram definitivamente esclarecidos.

Roque \& Jansen (2014) revisaram as espécies de mamíferos silvestres e sinantrópicos encontrados infectados com Leishmania spp. nas Américas, diferenciando-os entre hospedeiros e "potenciais reservatórios", sendo a última designação utilizada apenas quando os autores demonstraram o potencial de manutenção da infecção ou de transmissibilidade dos parasitos aos vetores, por meio de xenodiagnóstico positivo ou culturas de pele ou sangue (Tabela 1). 
Tabela 1. Mamíferos infectados por diferentes espécies de Leishmania nas Américas. Revisado por Roque \& Jansen 2014.

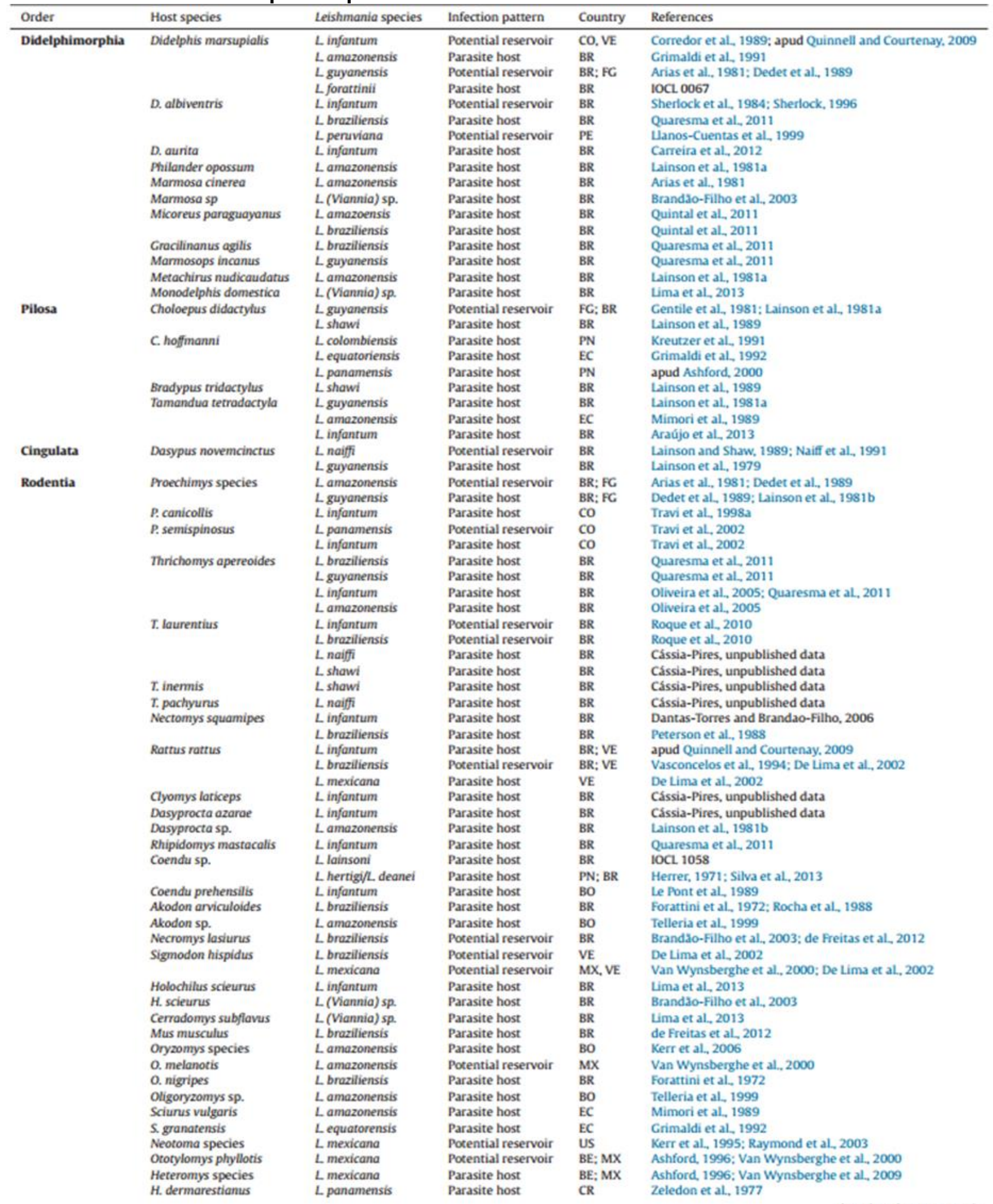




\begin{tabular}{|c|c|c|c|c|c|}
\hline Order & Host species & Leishmania species & Infection pattern & Country & References \\
\hline & Peromyscus yucatanicus & L mexicana & Potential reservoir & MX & Van Wynsberghe et al.., 2000 \\
\hline & Nyctomys sumichrasti & $L$ mexicana & Parasite host & $\mathrm{HN}$ & Lainson and Strangways-Dixon, 1964 \\
\hline & Reithrodontomys gracilis & $L$ mexicana & Parasite host & $\mathrm{HN}$ & Disney. 1968 \\
\hline & Agouti paca & L lainsoni & Potential reservoir & BR & Silveira et al., 1991 \\
\hline & Phyllotis andinum & L peruviana & Parasite host & PE & Llanos-Cuentas et al., 1999 \\
\hline & Cavia porcellus & Lenriettii & Parasite host & BR & Machado et al., 1994 \\
\hline \multirow[t]{12}{*}{ Carnivora } & Cerdocyon thous & $L$ infantum & Potential reservoir & BR & Deane and Deane, 1955; Courtenay et al., 1996 \\
\hline & & Lamazonesis & Parasite host & BR & apud Rotureau, 2006 \\
\hline & Speothos venaticus & L infantum & Potential reservoir & BR & Figueiredo et al., 2008: Lima et al., 2009 \\
\hline & Pseudalopex vetulus & $L$ infantum & Parasite host & BR & Curi et al., 2006: Luppi et al.. 2008 \\
\hline & Chrysocyon brachyurus & $L$ infantum & Parasite host & BR & Curi et al., 2006: Luppi et al., 2008 \\
\hline & Puma concolor & L infantum & Parasite host & BR & Dahroug et al., 2010 \\
\hline & Panthera onca & L infantum & Parasite host & BR & Dahroug et al., 2010 \\
\hline & Nasua nasua & L shawi & Parasite host & BR & Lainson et al.. 1989 \\
\hline & Potos flavus & L guyanensis & Parasite host & FG & Pajot et al., 1982 \\
\hline & & Lamazonensis & Parasite host & EC & Kreutzer et al.. 1991 \\
\hline & Conepatus chinga & Lamazonensis & Parasite host & BO & Telleria et al., 1999 \\
\hline & & L braziliensis & Parasite host & BO & Buitrago et al., 2011 \\
\hline \multirow[t]{13}{*}{ Primata } & Cebus apella & L shawi & Potential reservoir & BR & Lainson et al.. 1989 \\
\hline & Cebus xanthosternos & L infantum & Parasite host & BR & Malta et al., 2010 \\
\hline & Chiropotes satanas & L shawi & Potential reservoir & $\mathrm{BR}$ & Lainson et al., 1989 \\
\hline & Saguinus geoffroyi & L. amazonensis & Potential reservoir & $\mathrm{PN}$ & Herrer et al., 1973 \\
\hline & Aotus trivirgatus & L braziliensis & Potential reservoir & PN & Herrer and Christensen, 1976 \\
\hline & Aotus azarai & $L$ (Viannia) sp. & Parasite host & AR & Acardi et al., 2013 \\
\hline & Aotus nigriceps & L infantum & Parasite host & BR & Malta et al., 2010 \\
\hline & Callicebus nigrifrons & $L$ infantum & Parasite host & BR & Malta et al., 2010 \\
\hline & Alouatta guariba & L infantum & Parasite host & BR & Malta et al., 2010 \\
\hline & Leonthopitecus crysomelas & L infantum & Parasite host & BR & Malta et al., 2010 \\
\hline & Pithecia irrorata & L infantum & Parasite host & BR & Malta et al., 2010 \\
\hline & Saguinus imperator & $L$ infantum & Parasite host & $\mathrm{BR}$ & Malta et al., 2010 \\
\hline & Ateles paniscus & L amazonensis & Parasite host & BR & Lima et al.. 2012a \\
\hline \multirow[t]{14}{*}{ Chiroptera } & Carollia perspicillata & L. infantum & Potential reservoir & VE & De Lima et al., 2008 \\
\hline & Molossus molossus & L infantum & Parasite host & BR & Savani et al., 2010 \\
\hline & & L amazonensis & Parasite host & BR & Savani et al., 2010 \\
\hline & & $L($ Viannia $)$ sp. & Parasite host & BR & Shapiro et al.. 2013 \\
\hline & M. rufus & Lamazonensis & Parasite host & BR & Savani et al.. 2010 \\
\hline & Glossophaga soricina & L infantum & Parasite host & BR & Savani et al., 2010 \\
\hline & & L amazonensis & Parasite host & BR & Savani et al.. 2010 \\
\hline & & $L$ (Viannia) sp. & Parasite host & BR & Shapiro et al., 2013 \\
\hline & Nyctinomops laticaudatus & L amazonensis & Parasite host & BR & Savani et al.. 2010 \\
\hline & Eumops glaucinus & L amazonensis & Parasite host & $\mathrm{BR}$ & Savani et al., 2010 \\
\hline & E. auripendulus & L amazonensis & Parasite host & BR & Savani et al., 2010 \\
\hline & Artibeus literatus & L amazonensis & Parasite host & BR & Savani et al., 2010 \\
\hline & Sturnira lilium & Lamazonensis & Parasite host & BR & Savani et al., 2010 \\
\hline & Myotis nigricans & L amazonensis & Parasite host & $\mathrm{BR}$ & Savani et al., 2010 \\
\hline
\end{tabular}

Countries: AR - Argentine, BR - Brazil, CL - Chile, CO - Colombia, VE - Venezuela; FG - French Guiana; PE - Peru; PN - Panama; EC - Ecuador; BO - Bolivia; US - United States of America; BE - Belize; MX - Mexico; HN - Honduras; CR - Costa Rica.

IOC L*: Characterized Strains deposited in the Leishmania sp. Collection of the Oswaldo Cruz Institute (www.clioc.fiocruz.br). The number refers to the deposit number in CLIOC Catalogue.

Antes do desenvolvimento de técnicas bioquímicas, sorológicas e moleculares para a caracterização e identificação de isolados de Leishmania, só era possível se basear em características biológicas dos parasitos, tais como a morfologia de amastigotas e promastigotas e seu comportamento em meio de cultura ou no comportamento biológico da infecção em hamster. Os primeiros pesquisadores apenas podiam dizer que os isolados de animais silvestres em áreas endêmicas de LT humana eram provavelmente de L. braziliensis (Lainson 2010). 
Lainson e Shaw (1970) encontraram amastigotas compatíveis com Leishmania em exames histológicos de lesões dos roedores Oryzomys spp., Neacomys spinosus amoenus, Nectomys rattus e do marsupial Marmosa murina. Dos 46 animais que apresentaram lesões de pele, 21 (20\%) foram positivos para Leishmania sp. Isolados de Leishmania provenientes de infecção natural em Akodon arviculoides, Oryzomys nigripes e Oryzomys capito laticeps foram identificados por Forattini e colaboradores (1972; 1973). Lainson e colaboradores (1979) isolaram Leishmania de tatu galinha (Dasypus novemcinctus). Silveira e colaboradores (1991) isolaram pela primeira vez Leishmania lainsoni do roedor Agouti paca. Brandão-Filho e colaboradores (1994) realizaram um estudo tendo como alvo a investigação de pequenos mamíferos como prováveis reservatórios de Leishmania braziliensis em Amaraji, Pernambuco. Amastigotas em esfregaço do fígado e baço compatível com Leishmania spp. foram encontrados em amostras de Nectomys squamipes, Necromys lasiurus (syn. Bolomys lasiurus) e Rattus rattus (rato preto). Na Venezuela, De Lima e colaboradores (2002), também isolaram Leishmania braziliensis de Rattus rattus e Sigmodon hispidus (rato do algodão).

Em 2003, parasitos dos roedores brasileiros Necromys lasiurus e Rattus rattus foram conclusivamente classificados como $L$. braziliensis por meio de eletroforese enzimática multilocus (Brandão-Filho 2003). Um estudo realizado por Quaresma e colaboradores (2011), na Reserva Indígena Xakriabá, área endêmica para leishmanioses, localizada no norte de Minas Gerais, Brasil, encontrou, a partir de técnicas de PCR, Leishmania braziliensis, $L$. infantum e $L$. guyanensis circulando entre diferentes animais silvestres, sinantrópicos e domésticos presentes na reserva: duas espécies de roedores silvestres (Thrichomys apereoides e Rhipidomys mastacalis), uma de roedor sinantrópico (Rattus rattus) e três espécies de marsupiais (Didelphis albiventris, Gracilinanus agilis e Marmosops incanus). Foi o primeiro relato de $L$. guyanensis fora da região norte do país. 
Leishmania guyanensis comumente infecta seres humanos no Brasil, especialmente ao norte do rio Amazonas, e nos países vizinhos da Guiana Francesa e Suriname. São encontrados em hospedeiros silvestres como a preguiça Choloepus didactylus, o tamanduá-mirim Tamandua tetradactyla (Gentile et al. 1981, Lainson et al. 1981), roedores e marsupiais. Lainson e colaboradores (1981) isolaram L. guyanensis em Didelphis marsupialis, Proechimys guyannensis e Tamandua tetradactyla.

O roedor Proechimys guyannensis foi encontrado parasitado por $L$. amazonensis no norte do estado do Pará (Lainson \& Shaw 1972), assim como Proechimys cuvieri na Guiana Francesa (Dedet et al. 1985). Lainson e colaboradores (1981) isolaram L. amazonensis de Didelphis marsupialis, Philander opossum, Metachirus nudicaudatus, Proechimys guyannensis e Dasyprocta sp. Outros pequenos roedores silvestres como Oryzomys sp. também foram encontrados parasitados (Lainson \& Shaw 1968). Leishmania amazonensis foi identificado por PCR kDNA em Akodon spp. por Telleria e colaboradores (1999).

No Brasil, os canídeos são considerados os principais hospedeiros de L. infantum, especialmente os cães domésticos, que preenchem as condições necessárias para serem eficientes reservatórios deste parasito. Os cães são altamente susceptíveis à infecção, com uma grande proporção de assintomáticos por vários anos e até mesmo a vida inteira; por apresentarem intenso parasitismo cutâneo; e também pela proximidade das habitações humanas, que favorece a manutenção da transmissão do parasito (Dantas-Torres e Brandão-Filho 2006, Dantas-Torres 2007). Há também diversos relatos de infecção de cães domésticos por L. braziliensis (Aguilar et al. 1989, Madeira et al. 2003, 2006, Castro et al. 2007, Quaresma et al. 2011) e com infecção mista por L. infantum e L. braziliensis (Madeira et al. 2006, Quaresma et al. 2011).

Apesar de o cão ser considerado o mais importante reservatório doméstico da $L$. infantum, sendo responsabilizado pela manutenção de 
endemias nos grandes centros urbanos (Silva et al. 2001), a importância de Didelphis spp. como reservatórios silvestres vem sendo sugerida por vários autores, uma vez que sua capacidade sinantrópica facilita a ligação entre os ambientes peridoméstico e o silvestre (Lainson et al. 1969). Sherlock e colaboradores (1984) isolaram L. infantum de um Didelphis albiventris, sendo o primeiro mamífero silvestre não canino a ser achado com o agente da leishmaniose visceral no novo mundo. A partir de então $L$. infantum tem sido detectado frequentemente em Dildelphis spp. em áreas endêmicas do Brasil (Sherlock 1996, Cabrera et al. 2003, Humberg et al. 2012, Carreira et al. 2012) e da Colômbia (Corredor et al. 1989, Travi et al. 1994).

Várias espécies de canídeos silvestres também já foram encontradas parasitadas com L. infantum, como o lobo guará, Chysocyon brachyurus, o cachorro do mato, Cerdocyon thous, a raposa-do-campo, Lycalopex vetulus, e o cachorro-vinagre, Spheotos venaticus (Lainson et al. 1969, Curi et al. 2006, Figueiredo et al. 2008, Souza et al. 2010). Em 1969, Lainson e colaboradores já discutiam o papel do Cerdocyon thous como potencial reservatório de $L$. infantum no norte do Brasil e, em 1990, descreveram a eficiência desse canídeo como fonte de infecção.

Outros tripanossomatídeos também são encontrados com frequência em mamíferos silvestres (Herrera et al. 2008a e b, Rocha et al. 2013a e b, Roque et al. 2013). De Araújo e colaboradores (2013) detectaram por exames moleculares infecção mista em um tamanduá-mirim, Tamandua tetradactyla, com Trypanosoma cruzi, $T$. rangeli e $L$. infantum no estado do Pará, Brasil. Além disso, uma nova espécie de tripanossomatídeo ( $T$. caninum) foi recentemente descrita em cães domésticos no Brasil (Madeira et al. 2009). 


\subsection{Ciclos de Transmissão}

A epidemiologia das leishmanioses na região das Américas é complexa, com variação intra e inter-específica nos ciclos de transmissão, hospedeiros, vetores flebotomíneos, manifestações clínicas e resposta à terapia. Além disso, diferentes espécies de Leishmania podem circular na mesma área geográfica.

As espécies de Leishmania mantêm classicamente dois ciclos de transmissão: o domiciliar e o silvestre. O ciclo domiciliar, incluindo o intradomicílio e o peridomićlio, definido com sendo a área existente ao redor de uma residência num raio não superior a cem metros, envolve o homem, os animais sinantrópicos e domésticos e os vetores (flebotomíneos) domiciliados. Já o ciclo silvestre envolve os vetores e os reservatórios silvestres (Figura 2). A transmissão vetorial dos tripanossomatídeos para humanos é resultado da interação entre os ciclos silvestre e domiciliar, com a invasão do ecótopo silvestre pelo homem ou a invasão de vetores e/ou mamíferos silvestres, que trazem populações do parasito do ambiente silvestre permitindo a infecção humana (Barretto 1979, Lainson \& Rangel 2005, Rangel \& Lainson 2009).

Considera-se que o surgimento de surtos e epidemias de leishmanioses pode estar diretamente ligado à ecologia humana, a partir da introdução do ser humano em regiões onde existem naturalmente os vetores desta doença (Aguiar \& Medeiros, 2003). Porém, algumas espécies de flebotomíneos também podem ter modificado o seu comportamento, afetando seu papel na transmissão das leishmanioses ao adquirir hábitos domiciliares ou peridomésticos (Souza et al. 2001). 


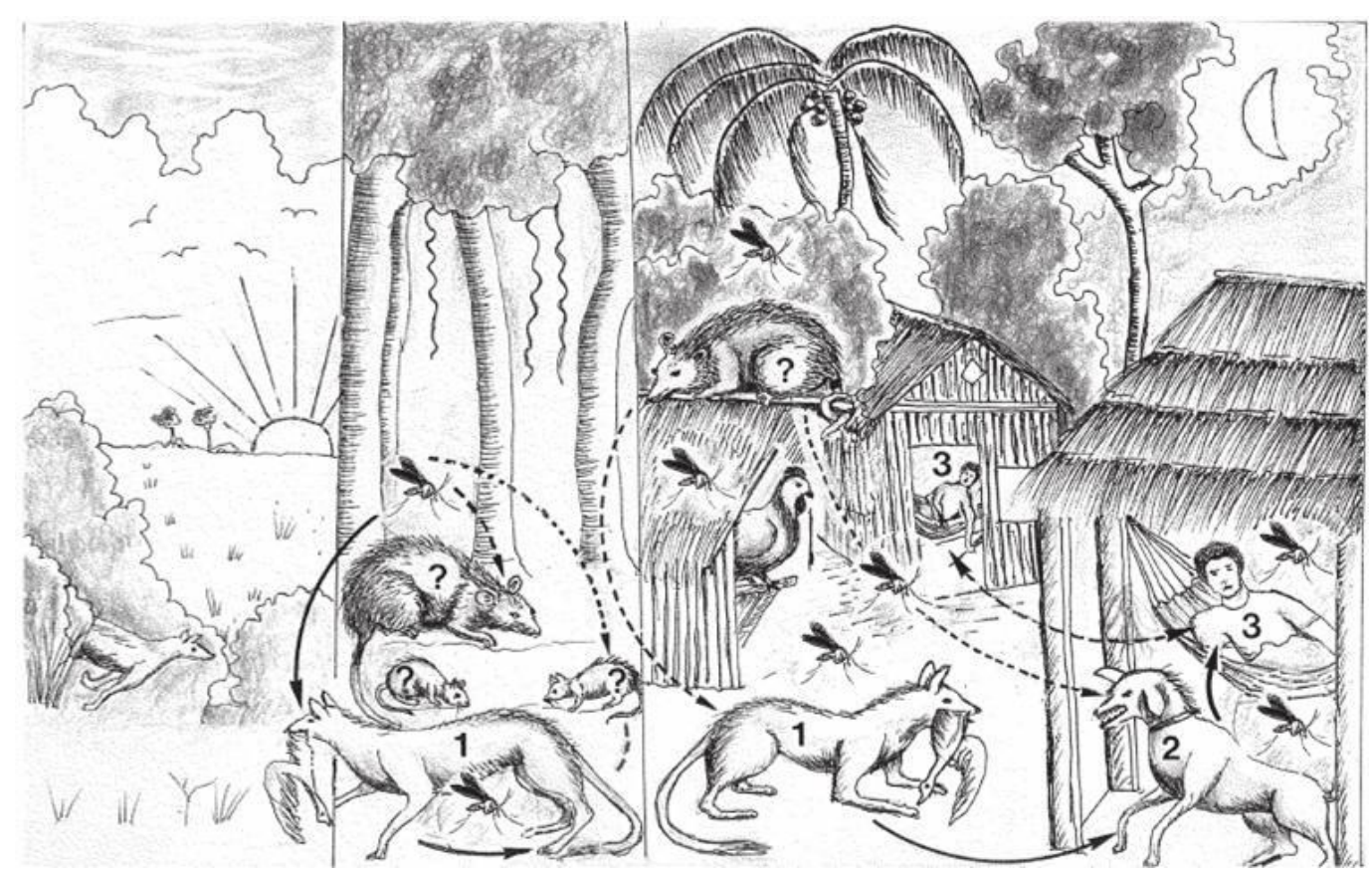

Figura 2. Eco-epidemiologia da leishmaniose visceral no norte do Brasil. O parasito Leishmania infantum, enzoótico proveniente de raposas silvestres e, possivelmente, outros animais selvagens (1), é mantido por uma população silvestre do mosquito palha Lutzomyia longipalpis. Invasão das moradas na borda da floresta por este flebotomíneo permite o estabelecimento da infecção canina e humana (2, 3), e o cão doméstico torna-se a principal fonte do parasito. Linhas contínuas indicam rotas definidas de transmissão. Linhas quebradas representam possível transmissão com outros animais selvagens e, possivelmente, o próprio homem, servindo como fonte de infecção para flebotomíneos. Fonte: Lainson \& Rangel (2005).

\subsection{Estratégias de Controle no Brasil}

Há 60 anos, o programa de controle da leishmaniose visceral no Brasil é baseado em três principais medidas de controle: diagnóstico e tratamento precoce dos casos humanos, triagem imunológica e eutanásia de cães soropositivos e uso de inseticidas contra flebotomíneos (Dantas-Torres \& Brandao-Filho 2006). A tendência crescente de casos de LV observado no Brasil e a propagação de transmissão para áreas anteriormente não afetadas levantam dúvidas sobre o impacto das medidas de controle em 
curso (Romero \& Boelaert, 2010).

Segundo Karagiannis-Voules e colaboradores (2013), as dificuldades no diagnóstico e a subnotificação dos casos são os principais obstáculos para a implementação de um programa de controle das leishmanioses bem definido. Romero \& Boelaert (2010) reforçam que o fortalecimento da capacidade do sistema de vigilância é essencial para evitar a subnotificação de casos humanos e acompanhar o comportamento da infecção na população canina.

A eutanásia de cães parece ser a intervenção menos aceitável pela população e pode ter sua eficiência reduzida pela rápida substituição dos cães eliminados por filhotes suscetíveis. Já o controle dos vetores é bem mais aceito pelas populações afetadas, porém, é necessário um melhor conhecimento da sazonalidade e comportamento do vetor, para intervenção adequada. As evidências atuais indicam que nebulização espacial no peridomicílio possui baixa eficácia, uma vez que a reinfestação é muito rápida. Coleiras impregnadas com inseticidas para os cães parecem ter um efeito residual mais longo e vantagens sobre os outros métodos, uma vez que o processo de liberação dessas coleiras permite que o seu princípio ativo se distribua diretamente sobre a pele do cão, evitando perdas por evaporação. Porém, este método ainda apresenta um custo elevado para a maior parte da população. As vacinas de cães já registradas no Brasil têm algum efeito protetor contra LV canina, mas nenhuma delas foi devidamente avaliada como medida de controle contra LV humana (Romero \& Boelaert, 2010). Além disso, a vacinação pode resultar em resultados sorológicos falsos positivos para Leishmania infantum em cães.

Com relação aos hospedeiros e potenciais reservatórios, as investigações são geralmente verticais e pontuais não refletindo as condições epidemiológicas. O caráter zoonótico das leishmanioses, a existência de espécies vetoras nativas com potencial sinantrópico e os processos de urbanização/fragmentação de habitats, com a invasão do 
ambiente silvestre pelo homem, levando ao aumento da interação entre os ciclos silvestre e doméstico, são fatores que devem ser analisados para subsidiar estratégias efetivas de vigilância e controle.

\subsection{Diagnóstico laboratorial de Leishmania spp.}

O diagnóstico laboratorial de Leishmania spp. é representado fundamentalmente por três grupos de exames: parasitológicos, imunológicos e moleculares. A demonstração direta da forma amastigota do parasito em macrófagos é realizada por exame microscópico após os procedimentos de escarificação, biópsia com impressão por aposição ou punção aspirativa. A especificidade da microscopia é elevada, mas a sua sensibilidade é baixa. Com o achado do parasito temos o diagnóstico conclusivo. Srivastava et al. (2011) classificam a visualização do parasito em macrófagos como padrão ouro para o diagnóstico, porém, devido à dificuldade do achado direto do parasito, diversos autores afirmam não existir um método que possa ser classificado como padrão-ouro para o diagnóstico da infecção por Leishmania spp (Wilson 1995, Romero \& Boelaert 2010).

Os testes imunológicos, por meio da detecção da presença de anticorpos anti-Leishmania ou antígenos do parasito, são mais comumente utilizados e são considerados indispensáveis, uma vez que sinalizam a infecção já que os anticorpos estão em solução no plasma, portanto são homogeneamente distribuídos. Para os cães no Brasil, o teste de imunofluorescência indireta (IFI), o ensaio imunoenzimático (ELISA) e o teste imunocromatográfico rápido de duplo percurso - TR DPP específico para $L$. infantum são os utilizados na rotina. O TR DPP emprega uma combinação de proteína A conjugada com partículas de ouro coloidal e antígenos recombinantes para Leishmania K28 (fragmentos K26, K39 e K9). São ligados à fase sólida de uma membrana de nitrocelulose para detectar 
anticorpos específicos para Leishmania em sangue total, soro ou plasma (Schubach, 2011).

A especificidade dos ensaios sorológicos pode ser variável, podendo apresentar reação cruzada, com Trypanosoma cruzi, por exemplo, nos testes dirigidos aos anticorpos anti-Leishmania (Ferreira et al. 2007, Brasil 2010). Também há relatos de reação falso negativa em pacientes humanos e caninos com leishmanioses (Brasil 2010). Embora o desempenho dos testes varie entre diferentes estudos, os mais recentes têm relatado sensibilidades elevadas (Srivastava et al. 2011). Os testes sorológicos são raramente usados no diagnóstico de LTA, porque a sensibilidade pode ser variável, devido ao número de anticorpos circulantes contra parasitos causadores que tende a ser baixo.

Atualmente, os métodos moleculares vêm sendo amplamente utilizados para confirmar os resultados dos testes imunológicos e para fins de pesquisa. Porém, também há relatos de resultado falso negativo utilizando métodos moleculares, motivo pelo qual normalmente se utiliza mais de um tipo de teste diagnóstico para as leishmanioses. Contudo, vários trabalhos têm demonstrado que os ensaios moleculares permitem uma detecção rápida, sensível e específica de diversas doenças parasitárias além da possibilidade de caracterização dos microrganismos envolvidos na infecção, em variadas amostras clínicas, isolados de cultura, bem como pool de flebotomíneos (Lachaud et al. 2001, Schoönian et al. 2003, Cortes et al. 2004, Saraiva et al. 2010), havendo destaque para a reação em cadeia da polimerase (PCR - polymerase chain reaction).

\subsubsection{PCR}

Atualmente estão disponíveis várias técnicas utilizando iniciadores com diferentes alvos de genes, por exemplo, RNA ribossomal (rRNA), DNA ribossomal (rDNA), minicírculos do DNA do cinetoplasto (kDNA), entre 
outros. Os vários ensaios de diagnóstico baseados em PCR visando regiões diversas do genoma de Leishmania e usando diferentes primers para a amplificação possuem sensibilidades e especificidades distintas. Cada método de PCR é afetado por diversas variáveis e deve ser selecionado de acordo com o objetivo específico (diagnóstico da doença, gestão clínica, detecção de infecção assintomática, identificação das espécies, etc.), com a amostra disponível para a extração de DNA e com as instalações e conhecimento técnico disponível (Cruz et al. 2013). Ensaios de PCR são bastante atraentes, mas estimar a sua precisão e reprodutibilidade ainda constitui um prioridade de pesquisa (Romero \& Boelaert 2010). A PCR em tempo real (qPCR) representa o último avanço na tecnologia da PCR, permitindo a amplificação, detecção e quantificação de DNA em uma única etapa, o que agiliza a obtenção de resultados e minimiza o risco de possíveis contaminações, além de ser altamente sensível comparada com outras técnicas (Paiva-Cavalcanti et al. 2009).

Os primers que possuem como alvo minicírculos do DNA do cinetoplasto (kDNA) possuem mais chance de amplificação, uma vez que o alvo está presente em 10.000 cópias por célula, que são distribuídas em cerca de 10 classes diferentes de sequências. Além disso, a sequência do minicírculo já é conhecida para maioria das espécies de Leishmania e possui uma região variável que possibilita a diferenciação dos diversos grupos ou complexos de espécies (Aransay et al. 2000).

A PCR-ITS1 utiliza primers que amplificam a região espaçadora interna do DNA ribossômico (ITS) 1 de Leishmania spp. com fragmento que varia entre 300 e 350pb, dependendo da espécie. Não é tão sensível como outros primers, no entanto, quando realizado PCR-ITS1 nested, um nível de sensibilidade idêntico a outros primers mais sensíveis pode ser conseguido.

Outra estratégia de PCR tem como alvo a amplificação da região polimórfica do D7 do gene 24Sa rRNA, utilizando como iniciadores os oligonucleotídeos D75 e D76 que correspondem a sequências conservadas 
dos genomas de tripanossomatídeos, com fragmento de $\sim 225 \mathrm{pb}$ sugestivo de Leishmania spp., 240pb para Trypanosoma rangeli e $\sim 270$ a 290pb para Trypanosoma cruzi (Briones et al. 1999, Souto et al. 1999, Schijman et al. 2006). Esta estratégia pode ser uma ferramenta rápida e sensível para o diagnóstico diferencial de infecção por diferentes tripanossomatídeos em hospedeiros de áreas endêmicas. 


\section{JUSTIFICATIVA}

Cada área de transmissão deve ser considerada uma unidade biológica em particular, uma vez que o potencial de transmissibilidade das espécies de reservatórios pode ser influenciado por diferenças regionais, como a utilização da paisagem pelo homem, diferentes padrões de virulência das subpopulações de parasitos, diferentes populações de hospedeiros e vetores e comportamento de possíveis reservatórios sinantrópicos. O Cerrado é um bioma complexo e diversificado no Brasil central, onde várias espécies de possíveis hospedeiros e vetores nativos de Leishmania spp. estão presentes. Porém, a circulação dos tripanossomatídeos em ciclos silvestres e a caracterização da dinâmica desses ciclos no Cerrado continuam pouco investigadas.

No Distrito Federal, a transmissão da Leishmaniose Visceral teve início na região norte, no ano de 2005, em núcleos rurais e condomínios próximos a unidades de conservação, e nos últimos anos tem sido registrado aumento nos casos de Leishmania infantum em cães domésticos por todo o DF. Portanto, estudos sobre hospedeiros e possíveis reservatórios de Leishmania spp. em diferentes áreas do DF são de fundamental importância para a definição das estratégias de vigilância e controle, uma vez que a identificação da infecção por Leishmania spp. em pequenos mamíferos silvestres possibilitará definir a importância destes animais no ciclo epidemiológico dos parasitos em questão, como por exemplo, com informações sobre até que ponto existe um transbordamento (spill over) de Leishmania spp. do ambiente silvestre para o domiciliar ou se o ciclo da Leishmania infantum está se mantendo apenas entre os cães das residências.

O Parque Nacional de Brasília (PNB) e a Reserva biológica da contagem (Rebio) são unidades de conservação federais de proteção 
integral, ricas em espécies de mamíferos do cerrado, localizadas total ou parcialmente na região administrativa de Sobradinho, região norte do DF, áreas adequadas para o desenvolvimento do presente trabalho. 


\section{OBJETIVOS}

\subsection{Objetivo geral}

Estudar o ciclo de transmissão da Leishmania spp. entre os mamíferos silvestres e domésticos, no interior e entorno do Parque Nacional de Brasília (PNB) e Reserva Biológica da Contagem (Rebio da Contagem).

\subsection{Objetivos específicos}

1. Diagnosticar, por meio de técnicas moleculares, as espécies de Leishmania que estão infectando os hospedeiros silvestres do PNB e Rebio da Contagem e os cães domésticos do entorno;

2. Avaliar se as espécies de Leishmania que estão infectando os animais silvestres dentro das unidades de conservação são as mesmas espécies que estão infectando os cães domésticos no entorno;

3. Calcular a proporção de mamíferos silvestres positivos para Leishmania spp., entre os capturados, em áreas do PNB e Rebio da Contagem;

4. Analisar se existe diferença na frequência de Leishmania spp. entre as espécies de mamíferos silvestres capturadas e entre as unidades de conservação;

5. Comparar a positividade dos testes de diagnóstico utilizados na determinação da infecção por Leishmania spp.. 


\section{MATERIAL E MÉTODOS}

\subsection{Biossegurança e ética}

Para diminuir os riscos de transmissão de doenças aos pesquisadores, seja por contato direto (mordidas e arranhaduras) ou por contato indireto (urina, fezes, secreções, sangue, fômites ou aerossóis), foram adotadas medidas de segurança. Foram utilizados equipamentos de contenção e de proteção individual, como luvas de raspa de couro, luvas de procedimento e máscaras, e de hábitos higiênicos, como a desinfecção das armadilhas.

A equipe do projeto manteve uma conduta adequada no manejo dos animais seguindo as orientações vigentes para evitar a dor nos indivíduos pesquisados e todo o esforço para proporcionar conforto e a reintegração ao ambiente natural foi garantido. O projeto foi aprovado, sob o aspecto ético e legal, pelo Comitê de Ética no Uso Animal (CEUA) do Instituto de Ciências Biológicas da Universidade de Brasília (UnBDOC n¹05819/2011) (Anexo 1). A captura e a coleta dos animais silvestres no interior das Unidades de Conservação foram realizadas mediante autorização para atividades com finalidade científica, $\mathrm{n}^{\circ}$ 29486-4, emitida pelo órgão responsável, Instituto Chico Mendes de Conservação da Biodiversidade (ICMBio) (Anexo 2).

\section{2 Áreas de Estudo}

O estudo foi realizado em duas Unidades de Conservação Federais no Distrito Federal, Parque Nacional de Brasília (PNB) e Reserva Biológica da Contagem (Rebio) (Figura 3), durante os meses de novembro de 2011 a julho de 2012. Além disso, foi pesquisado o entorno dessas áreas que 
compreendem o Núcleo Rural Lago Oeste e condomínios do Grande Colorado (Figura 4). O clima predominante da região, segundo a classificação de Köppen, é tropical de altitude CWa e CWb, com uma estação fria e seca no período de inverno (abril a setembro) e uma estação quente e chuvosa no período de verão (outubro a março).

A Reserva Biológica da Contagem possui uma área total aproximada de 3.460 hectares, de acordo com seu Decreto de Criação de 13 de dezembro de 2002. A Rebio da Contagem está situada na Região Administrativa de Sobradinho - RA V, DF. Seus limites descrevem uma poligonal que engloba a cabeceira do Ribeirão da Contagem e parte de sua microbacia, abrangendo as encostas e o topo da Chapada da Contagem, próxima aos condomínios do Grande Colorado, no entorno da Vila Basevi e na extremidade leste do Núcleo Rural Lago Oeste. A Rebio abriga várias das fitofisionomias presentes no Cerrado, entre elas as formações campestres (campo sujo e campo limpo), cerrado sentido restrito, veredas e matas de galeria, segundo formações propostas por Ribeiro e Walter (1998) para o Bioma Cerrado.

O Parque Nacional de Brasília abrange atualmente uma área de 42.389,07 hectares, de acordo com os limites alterados pela Lei 11.285, de 8 de março de 2006. Está situado em sua maior parte na Região Administrativa de Brasília - RA I, mas também sobrepõe as Regiões Administrativas de Brazlândia - RA V e de Sobradinho - RA V e o município de Padre Bernardo/GO. Na extremidade nordeste do PNB, separados pela DF-001, estão o Núcleo Rural Lago Oeste e a Reserva Biológica da Contagem. O PNB situa-se na Chapada da contagem em toda sua extensão norte e oeste. Engloba córregos que nascem no contato da chapada da Contagem com a Depressão do Paranoá. Os córregos que se situam no Parque Nacional de Brasília são afluentes do Rio Paranoá. O PNB abriga grande parte das fitofisionomias presentes no Cerrado: as formações campestres (campo sujo, campo limpo, campo rupestre e campo de 
murundu), formações florestais (cerradão e matas de galeria) e as formações savânicas (cerrados e veredas), segundo formações propostas por Ribeiro \& Walter (1998) para o Bioma Cerrado.

Para as capturas dos pequenos mamíferos, foram escolhidas duas áreas de fitofisionomias diferentes em cada uma das Unidades de Conservação. No PNB foi amostrada uma área de formação florestal (mata de galeria) e outra de formação campestre (campo de murundu) e na Rebio, uma área de formação florestal (mata de galeria) e uma de formação savânica (cerrado sensu stricto/cerrado típico).

As matas de galeria estão localizadas ao longo dos córregos, ribeirões e principais ravinas e grotas. É facilmente identificada em imagem de satélite. Por ser uma formação florestal, possui um aglomerado de cobertura arbórea de porte elevado e o formato da área de influência é linear, acompanhando as redes de drenagem (Figura 3). A mata de galeria amostrada no PNB localiza-se ao longo do Ribeirão Tortinho, nas coordenadas $15^{\circ} 37^{\prime} 30,98^{\prime \prime} \mathrm{S}$ e $47^{\circ} 57^{\prime} 35,69^{\prime \prime} \mathrm{O}$, e a mata de galeria amostrada na Rebio localiza-se ao longo do Córrego Paranoazinho, nas coordenadas $15^{\circ} 40^{\prime} 25,3^{\prime \prime} \mathrm{S}$ e $47^{\circ} 51^{\prime} 55,7^{\prime \prime} \mathrm{O}$.

O campo de murundu é uma fitofisionomia que tem como característica a presença de murundus, que são microrrelevos positivos oriundos da erosão diferencial (Figura 3). Nos campos não há cobertura arbórea sobre os murundus. Visualmente, a identificação dos ambientes com murundus é a coloração escura da superfície com tons azulados ou acinzentados sobre a imagem em composição colorida. A área de estudo correspondente ao campo de murundu localiza-se nas coordenadas $15^{\circ} 37^{\prime} 52,2^{\prime \prime}$ S e $48^{\circ} 01^{\prime} 00,3^{\prime \prime} \mathrm{O}$.

O cerrado sentido restrito é a fitofisionomia típica do Bioma Cerrado e caracteriza-se pela presença de árvores baixas, inclinadas, tortuosas, com ramificações irregulares e retorcidas, geralmente com evidências de 
queimadas, e com arbustos e subarbustos espalhados (Figura 3). A área amostrada na Rebio é contigua a mata de galeria e encontra-se nas coordenadas $15^{\circ} 40^{\prime} 31,5^{\prime \prime} \mathrm{S}$ e $47^{\circ} 51^{\prime} 57,6^{\prime \prime} \mathrm{O}$. 


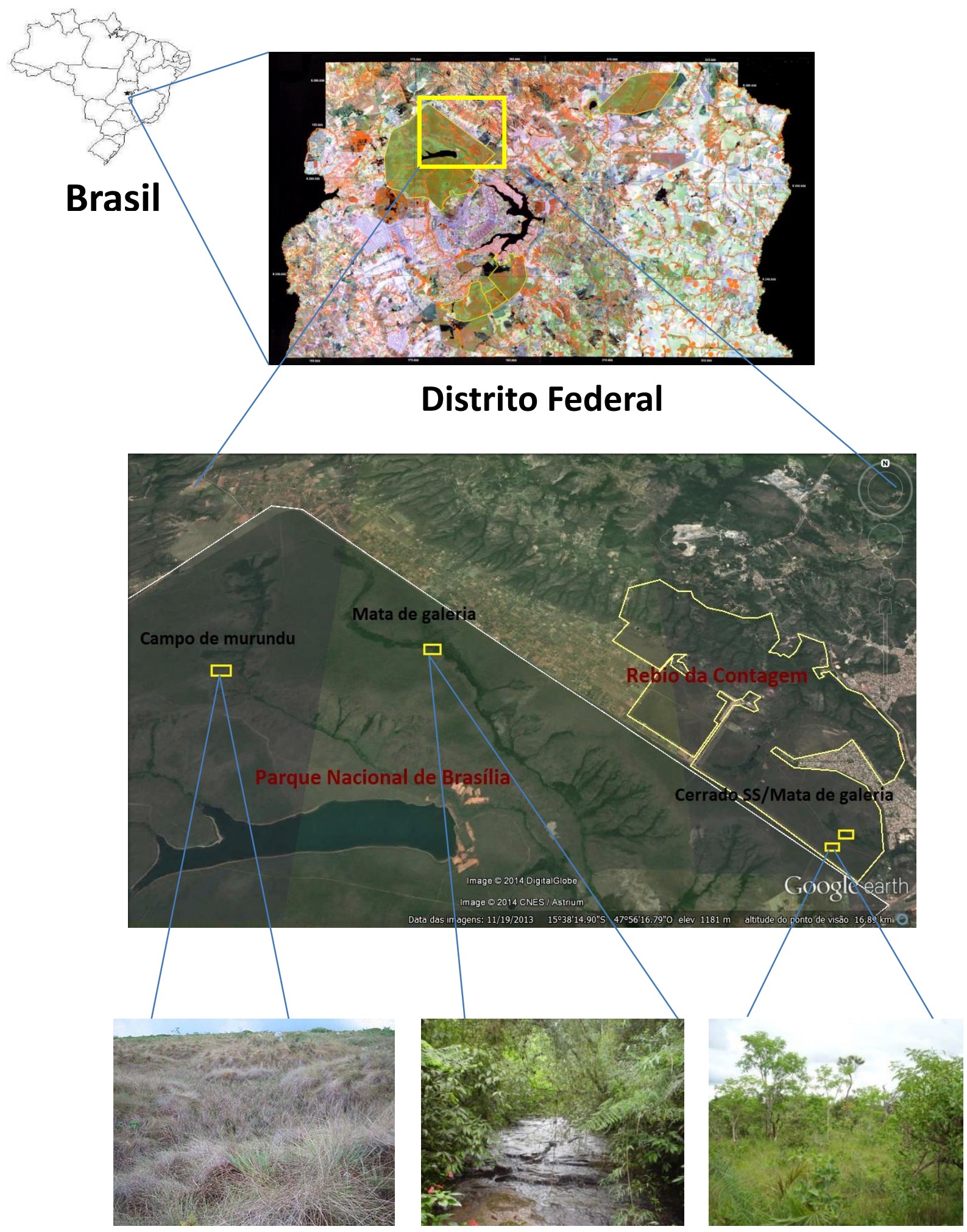

Figura 3. Reserva Biológica da Contagem e Parque Nacional de Brasília, com indicação dos pontos de amostragem. Os quadrados amarelos representam os gradeados em cada área amostrada (campo de murundu e mata de galeria no PNB e cerrado sensu stricto e mata de galeria na Rebio). 
As áreas escolhidas para o estudo dos cães domésticos encontramse na região administrativa de Sobradinho, localizada a $22 \mathrm{~km}$ do Plano Piloto, ao norte do Distrito Federal, em "bairros" localizados no entorno das Unidades de Conservação: o Grande Colorado e o Núcleo Rural Lago Oeste (Figura 4).

O Grande Colorado é uma região de Sobradinho formada por 10 condomínios de casas em processo de regularização fundiária. Está localizado na Chapada da Contagem, à margem esquerda da rodovia DF150 e à margem direita da DF-001. Faz limite, ao norte e a oeste, com a Reserva Biológica da Contagem, em uma das regiões mais altas do DF, com mais de 1200 metros de altitude. Foram amostrados dois condomínios: Vivendas Bela Vista (Coordenadas: 15³9'21"S 4751'55"O) e Mansões Colorado (Coordenadas: 1540'18"S 4751'21"O).

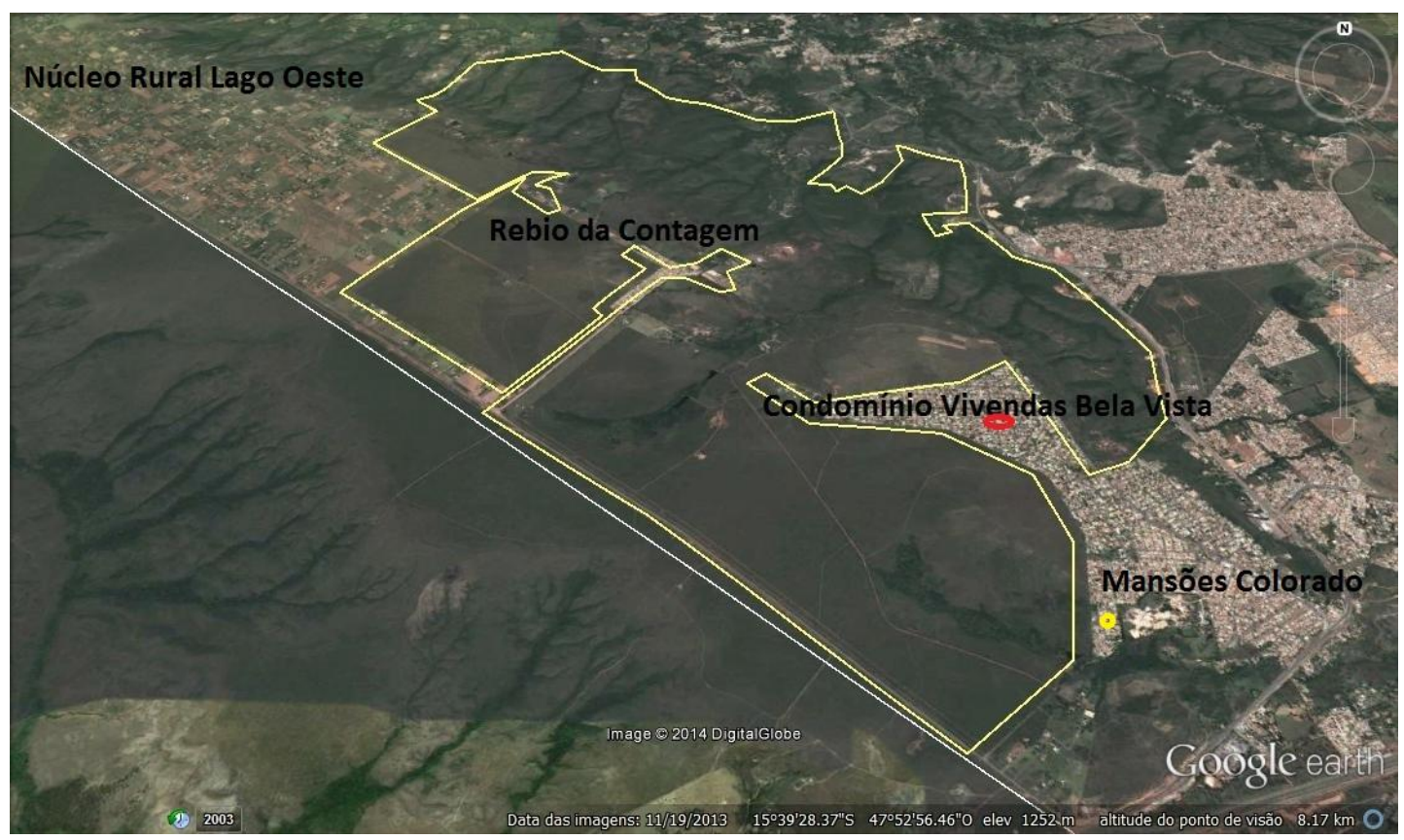

Figura 4. Áreas amostrais no entorno das unidades de conservação estudadas no Distrito Federal. 
O Núcleo Rural Lago Oeste é uma área rural de aproximadamente 35 $\mathrm{km}^{2}$ situada na Região Administrativa de Sobradinho, DF. Margeia o Parque Nacional de Brasília, tendo, como limites, a DF-001, sua principal via de acesso, a área de expansão do Parque, a Chapada da Contagem e a Reserva Biológica da Contagem (Rebio). O atual Núcleo Rural Lago Oeste foi formado a partir de quatro fazendas: Contagem de São João e Palmas/Rodeador que são de propriedade da União Federal, Buraco e Sítio do Mato, fazendas particulares e que se situam na borda da Chapada da Contagem.

\subsection{Captura dos mamíferos silvestres}

Para a captura dos mamíferos silvestres foram utilizadas armadilhas de contenção viva "live trap", de alumínio tipo Sherman e de arame tipo gaiola, distribuídas em gradeados montados nas áreas selecionadas (Figura 5). Na Rebio foi montado um gradeado com oito transecções paralelas $(A-H)$ cobrindo as duas fitofisionomias (Figura 6), com dimensões de $200 \times 70 \mathrm{~m}$, totalizando uma área de 1,4 ha (0,7 ha de formação florestal e 0,7 ha de cerrado). Cada transecção foi composta por 21 estações de captura (1-21), pontos onde foram posicionadas as armadilhas, espaçadas $10 \mathrm{~m}$ entre si. Cada fitofisionomia contou com 84 estações de captura, sendo que no cerrado foi posicionado um número bem maior de armadilhas do tipo Sherman, em 75 estações, enquanto as armadilhas tipo gaiola foram posicionadas em apenas nove pontos (um em cada linha). Na mata de galeria foram posicionados os dois tipos de armadilhas alternadamente, sendo que, as do tipo Sherman foram colocadas a uma altura de 1 a $2 \mathrm{~m}$, em locais propícios à presença de pequenos mamíferos arborícolas e escansoriais, como rede de cipós e galhos das árvores, para possibilitar a amostragem do estrato arbóreo. 


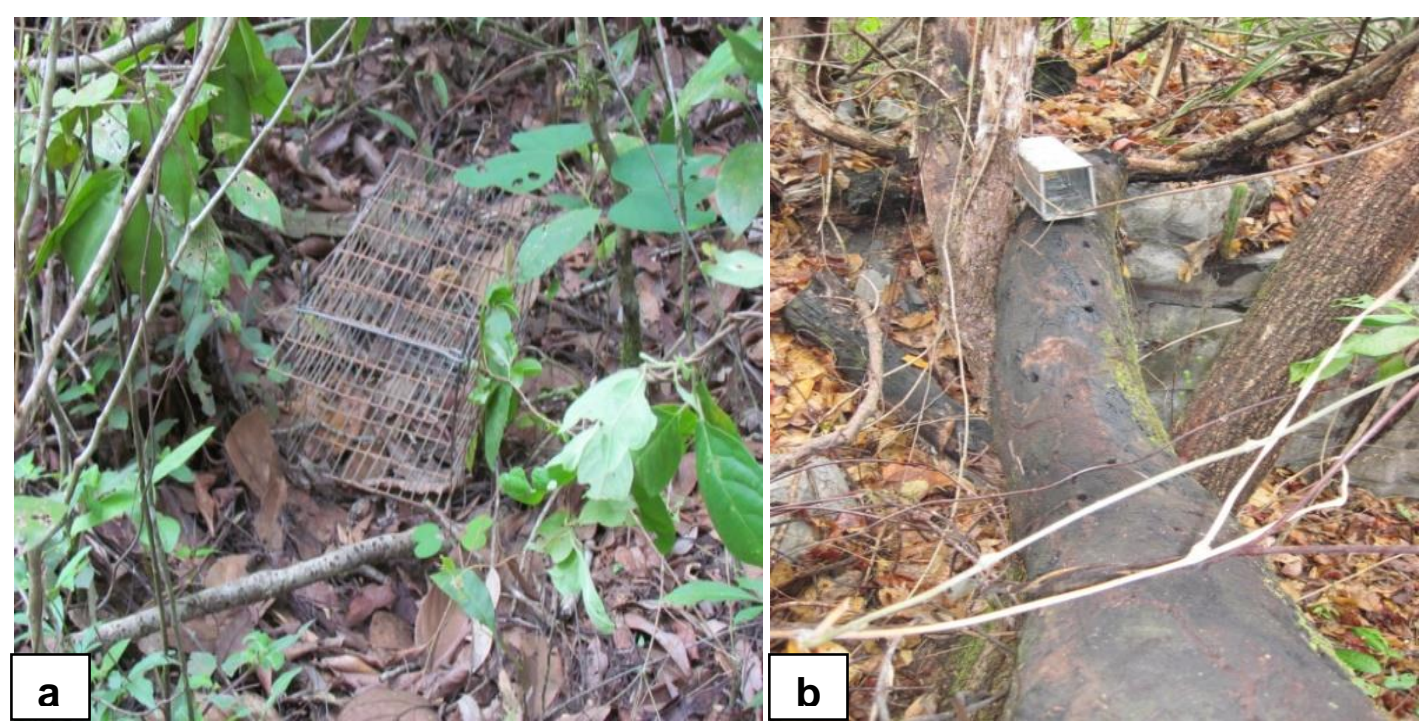

Figura 5. Armadilhas de contenção viva "live trap", de arame tipo gaiola (a) e de alumínio tipo Sherman (b).

No PNB foram montados dois gradeados de armadilhas, um em cada fitofisionomia. Na mata de galeria foi montado um gradeado com dimensões de $100 \times 40 \mathrm{~m}$, totalizando uma área de $0,4 \mathrm{ha}$, formado por cinco transecções paralelas (A-E) contendo, cada uma, 11 estações de captura (111) espaçadas $10 \mathrm{~m}$ entre si (Figura 7 ). As armadilhas tipo Sherman e gaiola foram posicionadas alternadamente nos pontos de captura dentro de cada linha e entre elas. Sendo que, as do tipo Sherman foram, em sua maioria, colocadas a uma altura de 1 a $2 \mathrm{~m}$, possibilitando a amostragem do estrato arbóreo. No campo de murundu foi montado um gradeado com dimensões de $90 \times 90 \mathrm{~m}$, totalizando uma área de 0,81 ha, formado por 10 linhas (A-J) contendo 10 estações de captura cada (1-10), espaçadas 10m entre si (Figura 8). Nesta grade, as armadilhas do tipo gaiola foram posicionadas em apenas um ponto de cada linha, enquanto as do tipo Sherman foram armadas nos demais pontos. 


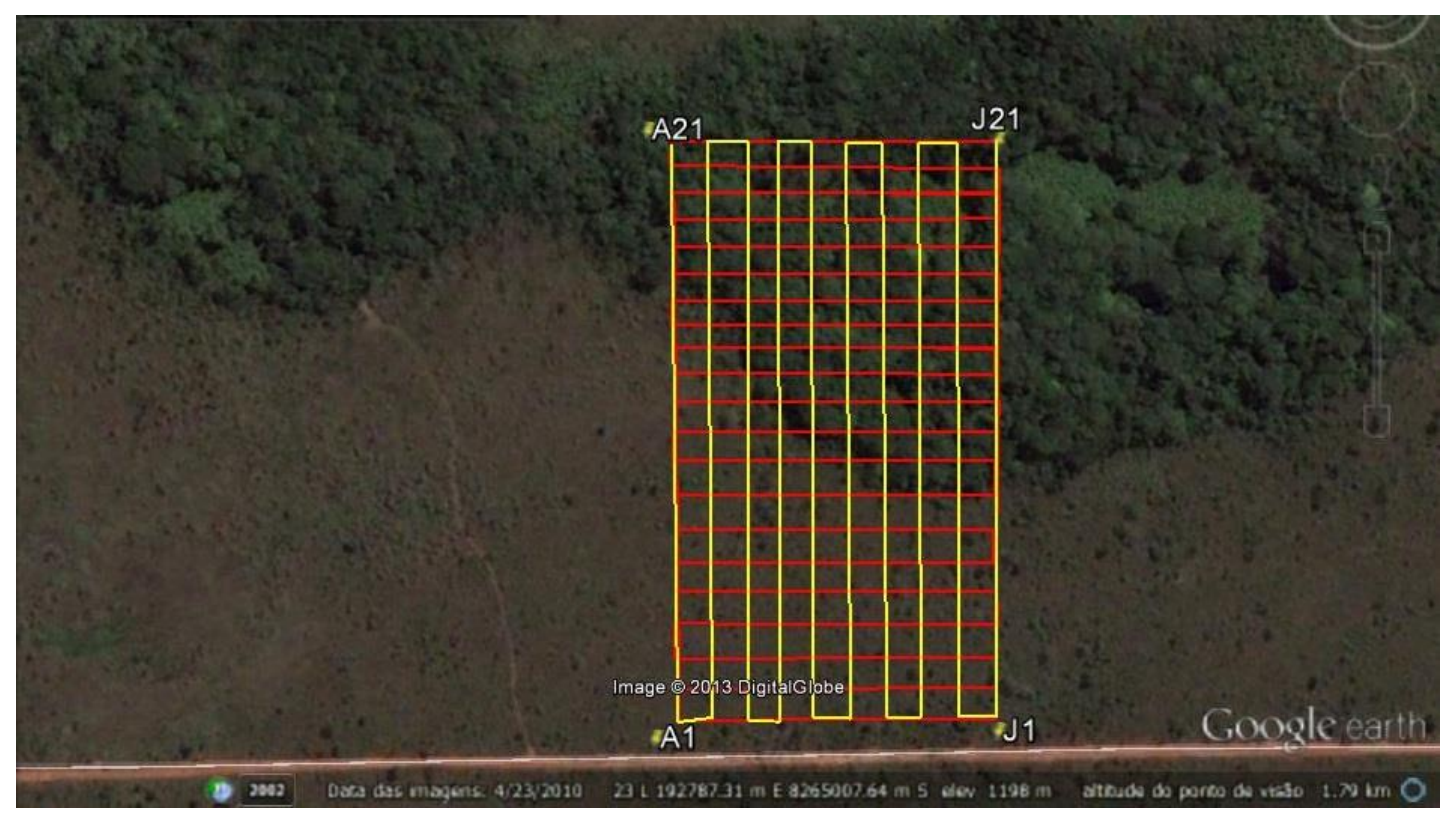

Figura 6. Grade montada na Reserva Biológica da Contagem.

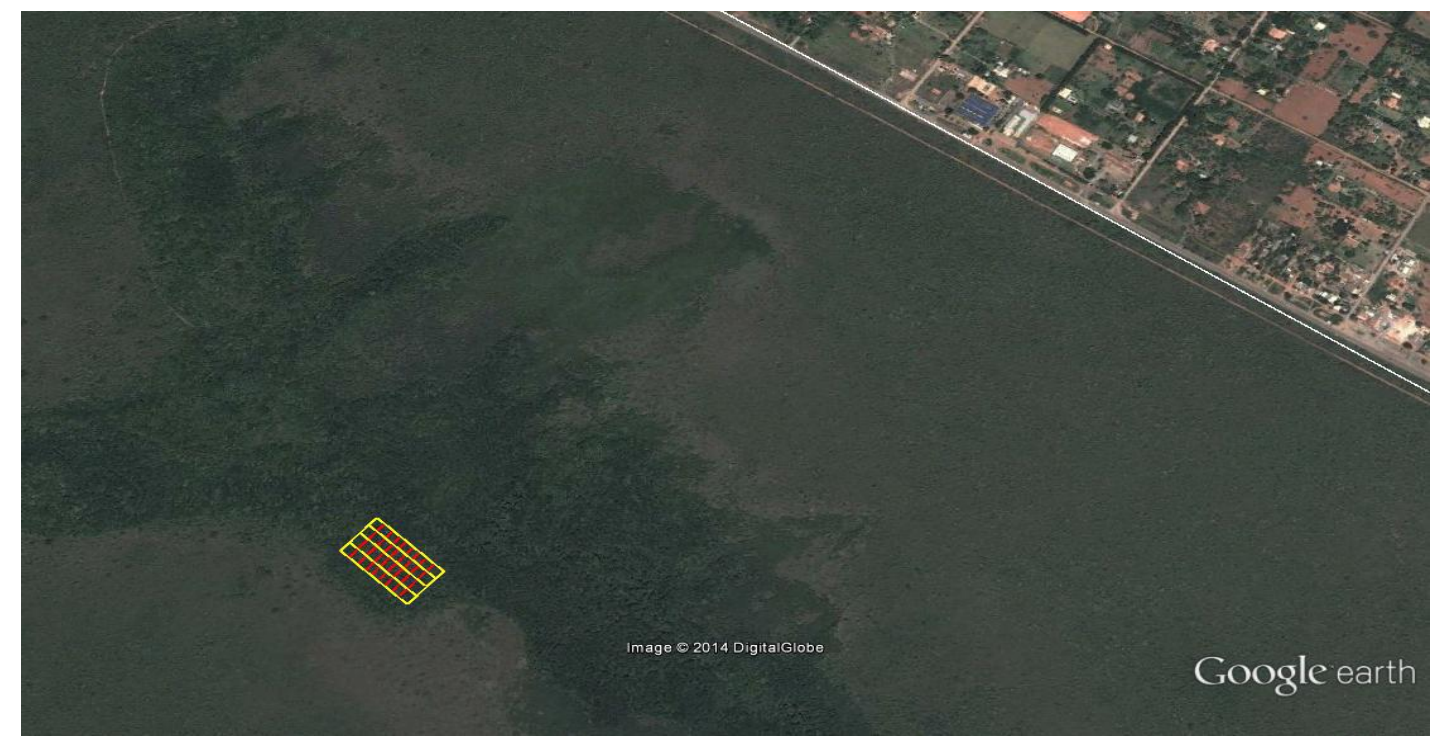

Figura 7.Grade montada na mata de galeria do Parque Nacional de Brasília. 


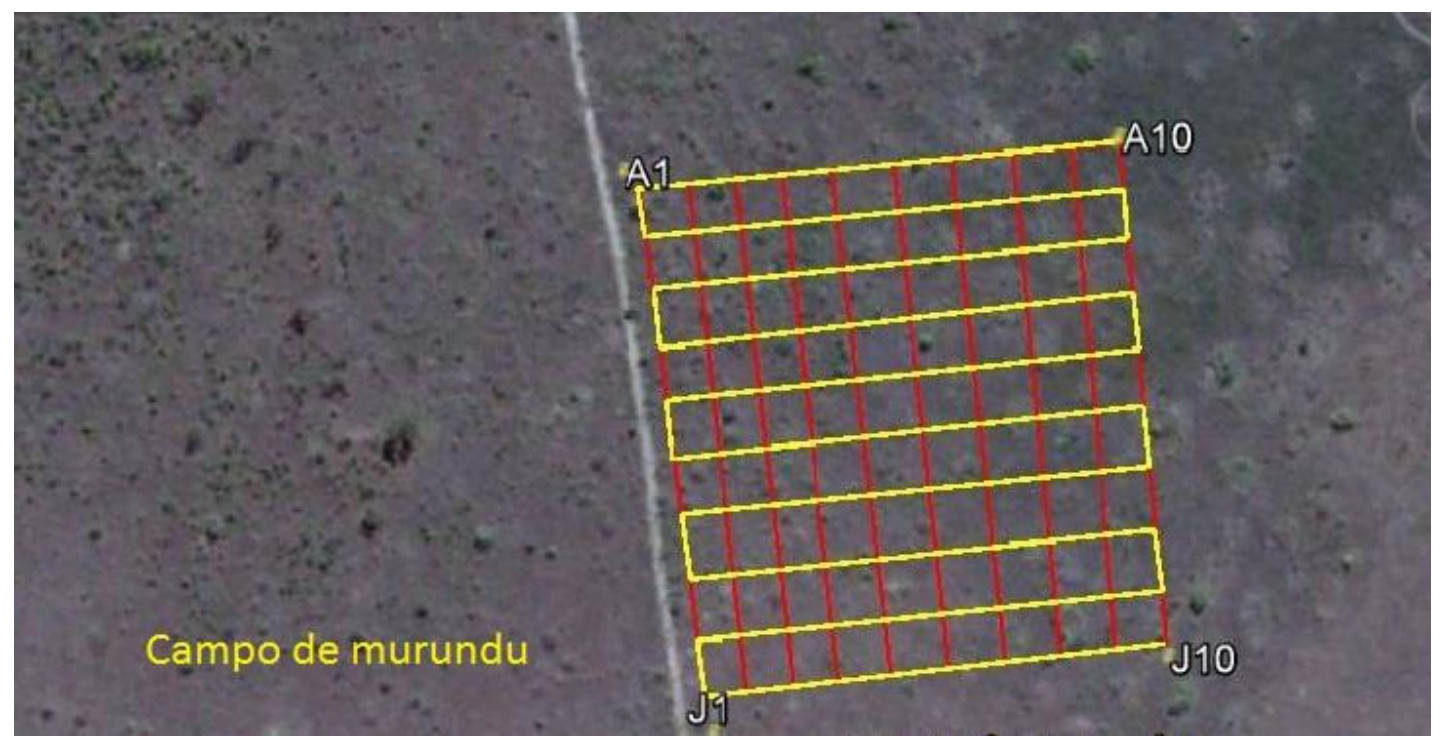

Figura 8. Grade montada no campo de murundu do Parque Nacional de Brasília.

As armadilhas foram iscadas com uma mistura de sardinha, farinha de milho, milho, pasta de amendoim e banana amassada e foi utilizada a metodologia de captura-marcação-recaptura dos pequenos mamíferos (Krebs 1999), onde o indivíduo capturado é marcado e posteriormente solto no mesmo local de captura.

As capturas foram realizadas por quatro noites consecutivas (uma campanha) por mês, ao longo de nove meses (novembro de 2011 a julho de 2012), sendo o esforço de captura (armadilhas-noite) calculado pelo número de armadilhas vezes o número de noites em que elas ficaram armadas. Foram realizadas nove campanhas de quatro noites, a cada 30 dias, porém, cada localidade (Rebio ou PNB) foi amostrada a cada 60 dias.

Após a captura, os animais foram encaminhados para uma base de campo temporária, montada pela equipe, onde foram manipulados (ver item 4.4). 


\subsection{Contenção dos mamíferos silvestres}

Os pequenos mamíferos foram contidos fisicamente com o auxílio de equipamentos de proteção individual, para aplicação intramuscular da associação anestésica cetamina e midazolan, na dosagem de 10 a 40 $\mathrm{mg} / \mathrm{Kg}$ e de 2 a $4 \mathrm{mg} / \mathrm{Kg}$ respectivamente, de acordo com a espécie.

Após a contenção química, os animais capturados foram identificados, pesados, sexados, verificados quanto à condição reprodutiva e medidos com relação aos comprimentos de cabeça-corpo, cauda, orelha interna direita e pata posterior direita. A identificação dos pequenos mamíferos em nível de gênero foi feita a partir de chaves de identificação taxonômica (Bonvicino et al. 2008) e a identificação específica foi realizada com auxílio dos mastozoólogos Marcelo Lima Reis e Marina Motta de Carvalho e baseada na comparação com exemplares da coleção de mamíferos do departamento de Zoologia do Instituto de Biologia da UnB. Os indivíduos foram marcados na orelha esquerda com brincos específicos para pequenos mamíferos (ZT 900, № 01, 7 7mm), submetidos a coleta de amostras biológicas (Figura 9) (ver item 4.5) e soltos, logo após o retorno da anestesia, nos respectivos locais de captura. 

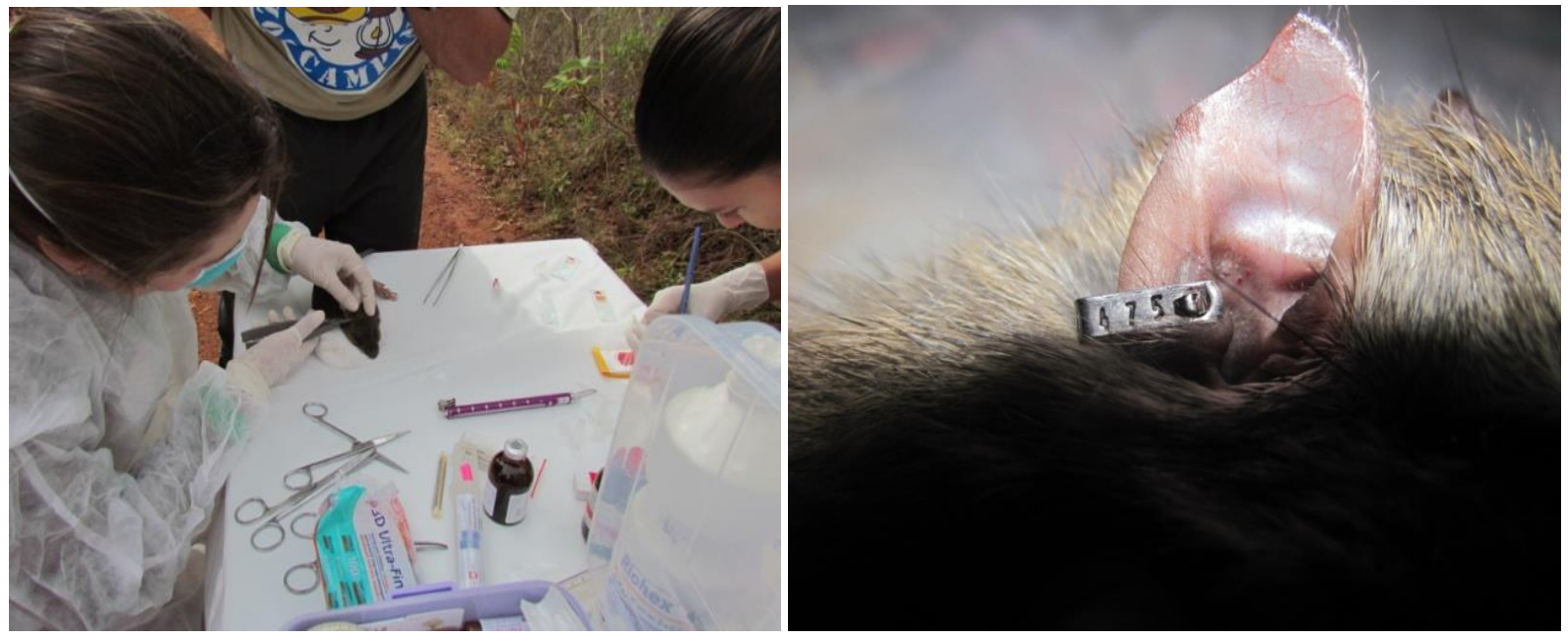

Figura 9. Coleta de material biológico e marcação dos pequenos mamíferos no campo.

\subsection{População e amostragem dos cães domésticos}

A amostragem dos cães domésticos do Condomínio Vivendas Bela Vista foi realizada por conveniência, nos dias 06 e 07 de junho de 2013, em animais com resultado positivo nos testes sorológicos para o diagnóstico da infecção por Leishmania spp., de acordo com inquérito amostral e censitário canino do ano de 2013, realizado pelo programa de controle de LV em cães (LVC), da Diretoria de Vigilância Ambiental no Distrito Federal (DIVAL). A abordagem nas residências do condomínio foi realizada em conjunto com a equipe da DIVAL, dentro de uma de suas campanhas.

A amostragem dos cães no Condomínio Mansões Colorado e do Lago Oeste foi realizada também por conveniência em setembro de 2013, tendo como critério de inclusão a proximidade do cão com os pontos amostrados nas unidades de conservação, aproximadamente $2 \mathrm{~km}$, e a autorização pelos proprietários para o acesso aos animais.

Os animais receberam um número de identificação de acordo com a ordem de entrada na pesquisa. Os mesmos números foram utilizados para a identificação das amostras coletadas. Durante a coleta foi preenchida ficha 
clínico-epidemiológica individual com os seguintes dados: nome do cão, sexo, idade, raça, cor, origem do animal, uso de coleira impregnadas com inseticidas, vacinação, condições de moradia e mobilidade, além do nome do proprietário e endereço.

\subsection{Coleta e processamento do material biológico}

Foram coletadas amostras de sangue total do plexo retro orbital dos pequenos mamíferos silvestres, até $1 \%$ do peso corporal, que foram transferidas para recortes de papel filtro Melitta $\AA$. Para coleta foram utilizadas seringas de $1 \mathrm{~mL}$ e agulha de $20 \times 5,5$ (roxa). Foram coletados também fragmentos de pele (ponta de orelha) dos pequenos mamíferos, usando tesoura cirúrgica curva fina/romba. A tesoura passou por processo de desinfecção com clorexidina degermante $2 \%$ e esterilização em bico de Bunsen entre um indivíduo e outro. Após excisão, os fragmentos foram transferidos para tubos eppendorf secos. As amostras foram transportadas no mesmo dia para o Laboratório de Leishmanioses do Núcleo de Medicina Tropical/UnB, onde foram mantidas a $4^{\circ} \mathrm{C}$ (sangue) e $-20^{\circ} \mathrm{C}$ (pele).

Dos cães domésticos, foram coletadas amostras de aproximadamente $5 \mathrm{~mL}$ do sangue total, por punção venosa da veia cefálica ou femural, as quais foram transferidas para tubos com anticoagulante (Vacuette ${ }^{\circledR} \mathrm{K} 3$ EDTA). O material foi transportado no mesmo dia para o laboratório de leishmanioses do Núcleo de Medicina Tropical/UnB, onde as amostras foram deixadas em repouso para a separação espontânea do plasma. Após a separação, foram coletados $500 \mu \mathrm{l}$ do plasma de cada amostra, colocados em eppendorf com a devida identificação e congelados a $-20^{\circ} \mathrm{C}$ para realização do teste imunocromatográfico rápido. O restante da amostra foi agitado com movimentos de inversão suave de maneira que o sangue e o soro se misturassem novamente. Do sangue total, foram separadas alíquotas de $300 \mu \mathrm{l}$ para a extração de DNA. 
As amostras foram processadas de acordo com o fluxograma abaixo:

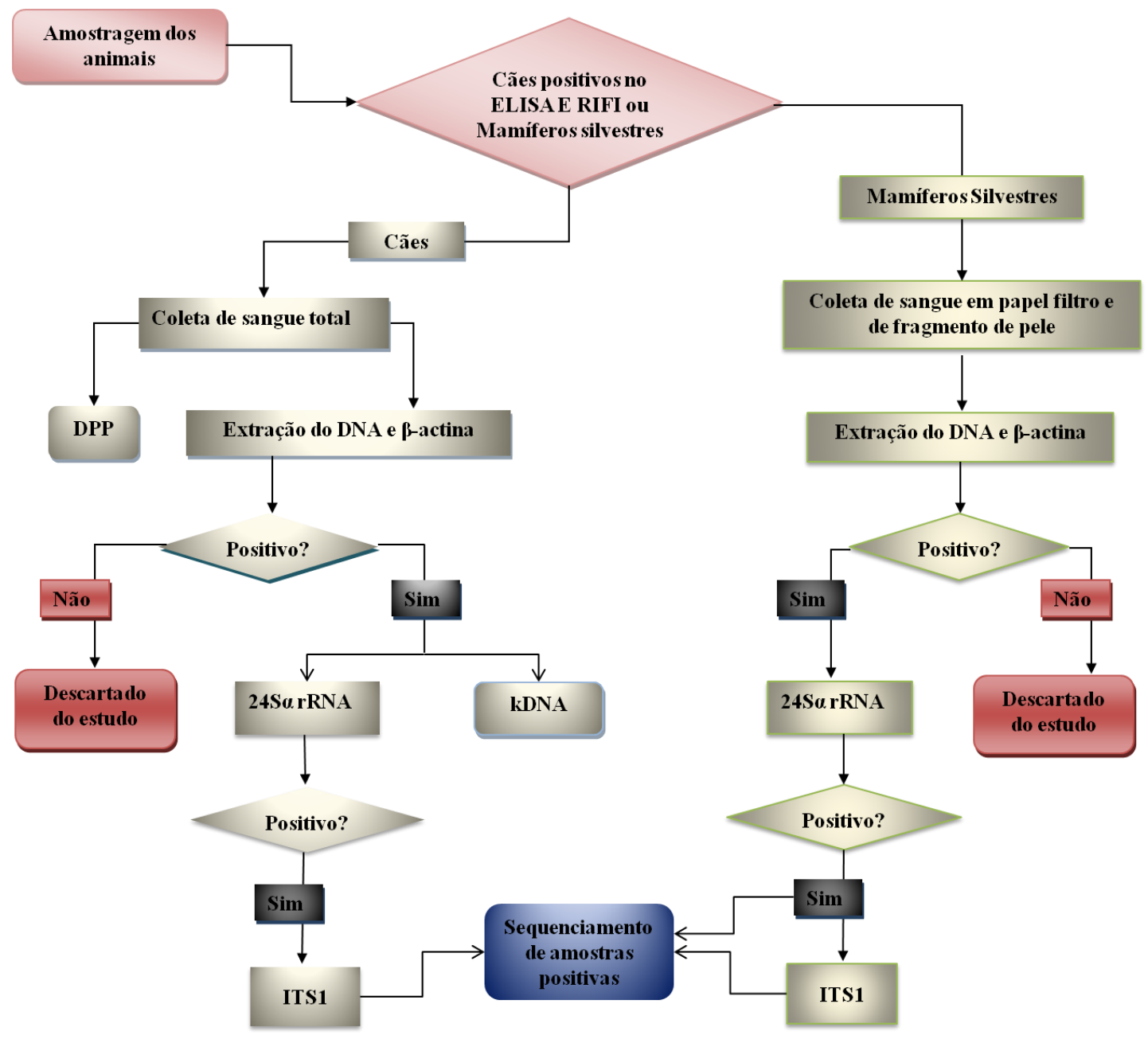

Figura 10. Fluxo do processamento das amostras biológicas dos cães e dos mamíferos silvestres. 


\subsubsection{Ensaio imunoenzimático (ELISA) e Reação de Imunofluorescência Indireta (RIFI)}

Os cães amostrados neste estudo haviam sido abordados anteriormente em inquérito censitário canino da DIVAL, dos quais foram coletadas amostras sanguíneas para realização os testes sorológicos ELISA (Enzyme Linked Immuno Sorbent Assay), a partir do kit EIE-LVC BioManguinhos/FIOCRUZ, e RIFI (Reação de Imunofluorescência Indireta), a partir do kit IFI-LVC Bio-Manguinhos/FIOCRUZ. Os exames foram processados pela DIVAL, utilizando protocolos padronizados por sua equipe técnica. Os resultados destes testes foram registrados nos livros específicos para registro de resultados do laboratório da DIVAL.

\subsubsection{Teste imunocromatográfico rápido de duplo percurso - TR DPP (Dual Path Platform)}

O Kit utilizado foi o TR DPP® Leishmaniose Visceral Canina BioManguinhos, Brasil. As amostras de plasma armazenadas a $-20^{\circ} \mathrm{C}$ foram deixadas a temperatura ambiente até que se descongelassem por completo. Em seguida, foram transferidos $5 \mu \mathrm{L}$ da amostra para o poço \#1 do suporte de teste e foram adicionadas duas gotas de tampão no mesmo poço. Após 5 minutos, quando a linha teste (azul) e controle (verde) da janela havia desaparecido, foram adicionadas quatro gotas de tampão no poço \#2 (tampão). $O$ teste correu por 10 minutos a temperatura ambiente. $O$ suporte foi colocado sobre uma superfície plana e em local iluminado, posicionado a uma distância de $30 \mathrm{~cm}$ a $50 \mathrm{~cm}$ entre o suporte de teste e os olhos do observador no momento da leitura. A interpretação do resultado seguiu rigorosamente as recomendações do fabricante. 


\subsubsection{Detecção de DNA de Leishmania spp. a partir de amostras biológicas}

\subsubsection{Extração do DNA das amostras de pele de pequenos mamíferos}

Os fragmentos de pele coletados dos animais capturados $\mathrm{e}$ acondicionados a $-20^{\circ} \mathrm{C}$ foram submetidos à extração do DNA. A metodologia para extração seguiu a orientação do fabricante do kit illustra tissue \& cells genomic Prep Mini Spin (GE Healthcare).

As amostras foram transferidas $(300 \mu \mathrm{L})$ para tubos eppendorf de $2 \mathrm{~mL}$ com tampa, lavados com $1 \mathrm{~mL}$ de PBS estéril, centrifugadas a $16.000 \times \mathrm{g}$ por 2 minutos e o sobrenadante descartado. O material foi triturado com $50 \mu \mathrm{L}$ de PBS estéril e centrifugado a $2.000 \times \mathrm{g}$ por 10 segundos. Esta etapa foi necessária para homogeneização do material. Foram adicionados $50 \mu \mathrm{L}$ da solução de $n^{0} 1$ e $10 \mu \mathrm{L}$ de proteinase $\mathrm{K}$ no material. As amostras foram misturadas no vórtex por 15 segundos e incubadas a $56^{\circ} \mathrm{C}$ por uma hora. Após o período de incubação, os tubos com as amostras foram agitados manualmente e centrifugados a $2.000 \times$ g por 10 segundos para obtenção de um pellet. Foram adicionados $5 \mu \mathrm{L}$ de RNAse $A$ de $20 \mathrm{mg} / \mathrm{mL}$ nas amostras, em seguida os tubos foram invertidos aproximadamente 25 vezes para homogeneizar o material, que foi incubado por 15 minutos à temperatura ambiente. Após o período de incubação, foram adicionados $500 \mu \mathrm{L}$ da solução de lise $\mathrm{n}^{\circ} 2$, o material misturado no vórtex por 15 segundos e incubado à temperatura ambiente por 10 minutos. Após este período, as amostras foram transferidas para a coluna já encaixada no tubo sem tampa, centrifugadas por $11.000 \times \mathrm{g}$ por 1 minuto, e o líquido filtrado que migrou para o tubo foi descartado. Foram adicionados $500 \mu \mathrm{L}$ da solução de lise ำ2 à coluna, o material centrifugado a $11.000 \times \mathrm{g}$ por 1 minuto e $\mathrm{o}$ líquido filtrado no tubo foi descartado. Em seguida, foram adicionados $500 \mu \mathrm{L}$ 
de tampão de lavagem à coluna, o material centrifugado a $11.000 \times \mathrm{g}$ por 3 minutos, e o tubo com o líquido filtrado foi descartado. A coluna com as amostras foi transferida para um novo tubo eppendorf de $2 \mathrm{~mL}$ com tampa. Foram adicionados à coluna $200 \mu \mathrm{L}$ de solução de eluição aquecida a $70^{\circ} \mathrm{C}$, deixando incubar por 1 minuto à temperatura ambiente. $O$ material foi centrifugando a $11.000 \times \mathrm{g}$ por 1 minuto, coletado no eppendorf e, após a quantificação do DNA no aparelho Nanovue ${ }^{\mathrm{TM}}$ Plus Spectrophotometer (GE Healthcare, EUA), armazenado a $-20^{\circ} \mathrm{C}$ até o momento da amplificação.

\subsubsection{Extração do DNA das amostras de sangue dos pequenos mamíferos}

O DNA das amostras de papel filtro contendo aproximadamente $0,4 \mathrm{ml}$ de sangue dos pequenos mamíferos silvestres foi extraído conforme descrito por Marques et al. (2001) e Romero et al. (2009). As amostras foram cortadas com "punch descartável para biópsia" (um punch por amostra) e os cortes circulares de papel com sangue de $7,0 \mathrm{~mm}$ de diâmetro, foram transferidos para tubos eppendorf de $1,5 \mathrm{~mL}$, com numeração correspondente aos indivíduos amostrados. Foram adicionados $40 \mu \mathrm{l} \mathrm{de}$ água Milli-Q (Millipore, Billerica, MA, EUA) nos tubos, os quais foram aquecidos a $70^{\circ} \mathrm{C}$ por 10 minutos e centrifugados a $16.000 \times \mathrm{g}$ durante dois minutos. Os sobrenadantes (preparados de DNA) foram transferidos para novos tubos eppendorf, quantificados no aparelho Nanovue ${ }^{\mathrm{TM}}$ Plus Spectrophotometer (GE Healthcare, EUA) e mantidos a $-20^{\circ} \mathrm{C}$ até à sua utilização. 


\subsubsection{Extração do DNA do plasma dos cães}

O DNA foi extraído no Laboratório de Leishmanioses do Núcleo de Medicina Tropical da UnB, utilizando o kit Wizard Genomic DNA Purification (Promega, Madison, WI, USA). Para cada amostra foi preparado um tubo eppendorf $(1,5 \mathrm{~mL}) \mathrm{com} 900 \mu \mathrm{L}$ de solução de lise celular. Foram adicionados $300 \mu \mathrm{L}$ da amostra no tubo com a solução de lise celular. O material foi ressuspendido com a pipeta. $O$ tubo foi misturado por inversão e incubado por 10 minutos à temperatura ambiente. Em seguida, o material foi centrifugado a $15.000 \times$ g por 20 segundos, o sobrenadante foi desprezado, o pellet no fundo do tubo foi submetido ao vórtex. Adicionou-se $300 \mu \mathrm{L}$ de solução de lise nuclear ao pellet, ressuspendendo-o com a pipeta. O material foi misturado por inversão, foram adicionados $100 \mu \mathrm{L}$ de solução de precipitação de proteínas, o material foi misturado no vórtex por 20 segundos e em seguida centrifugado a $15.000 \times \mathrm{g}$ por 3 minutos. Um tubo eppendorf $(1,5 \mathrm{~mL})$ foi preparado para cada amostra, contendo $300 \mu \mathrm{L}$ de isopropanol $100 \%$, para o qual foram transferidos os sobrenadantes. O tubo com o pellet foi descartado. O material foi centrifugado a $15.000 \times \mathrm{g}$ por 1 minuto, o sobrenadante desprezado. $O$ pellet que restou no tubo foi lavado com $300 \mu \mathrm{L}$ de etanol a $70 \%$. Novamente o material foi centrifugado por 1 minuto, o etanol foi descartado com a pipeta, e ficou secando ao ar por 15 minutos para a total evaporação do etanol. Foram adicionados em cada tubo, $100 \mu \mathrm{L}$ de solução de hidratação de DNA, agitando o tubo levemente para desprender o pellet do fundo. As amostras foram quantificadas no aparelho Nanovue ${ }^{\mathrm{TM}}$ Plus Spectrophotometer (GE Healthcare, EUA) e deixadas a $4^{\circ} \mathrm{C}$ overnight para que fossem submetidas ao processo de amplificação. 


\subsubsection{Reação em cadeia da polimerase (PCR)}

Antes de iniciar as PCRs com as amostras dos diferentes hospedeiros, foram realizados experimentos para padronizar e validar a técnica às condições de trabalho do laboratório (reagentes e equipamentos) para os diferentes alvos estudados. Parte dos experimentos descritos a seguir foi realizada no Laboratório de Leishmanioses do Núcleo de Medicina Tropical/Faculdade de Medicina/UnB e parte no Laboratório Multidisciplinar de Pesquisa em Doença de Chagas/Faculdade de Medicina / UnB.

\subsubsection{Controle endógeno da PCR - $\beta$-actina}

A $\beta$-actina é uma proteína com importantes funções celulares, que vem sendo utilizada como gene constitutivo em análises de PCR, aumentando assim a confiabilidade das análises.

Para controle endógeno da qualidade e integridade do DNA extraído das amostras dos cães (sangue) e dos mamíferos silvestres (sangue e pele) foi realizada a PCR com alvo na amplificação da proteína $\beta$-actina, com fragmento de 800 pb a partir dos iniciadores FW 5'- CGG AAC CGC TCA TTG CC -3' e BW 5'-ACC CAC ACT GTG CCC ATC TA -3' (du Breuil et al. 1993). As reações foram preparadas em um volume final de $25 \mu \mathrm{L}$, utilizando $0,2 \mu \mathrm{M}$ de cada iniciador, tampão de enzima $1 \mathrm{X}, 0,2 \mathrm{mM}$ de desoxirribonucleotídeos trifosfato (dNTPs), $1 \mathrm{mM}$ de $\mathrm{MgCl}$, 1,5 unidades de

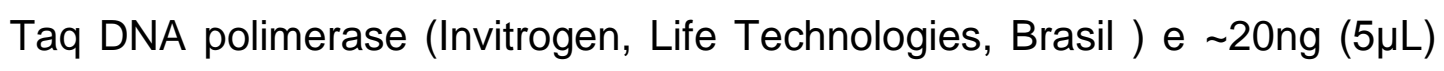
de DNA. A amplificação foi realizada em um termociclador TC-Plus (Techne, Inglaterra, UK) utilizando as seguintes condições: desnaturação inicial a $95^{\circ} \mathrm{C}$ por 5 minutos, 30 ciclos de desnaturação a $95^{\circ} \mathrm{C}$ por 30 segundos, pareamento a $60^{\circ} \mathrm{C}$ por um minuto, seguido de extensão a $72^{\circ} \mathrm{C}$ por 1 minuto e uma extensão final de $72^{\circ} \mathrm{C}$ por 5 minutos. 
Nas reações do DNA extraído das amostras dos cães foi utilizada como controle negativo água deionizada purificada em sistema Milli-Q ${ }^{\circledR}$. As amostras foram mantidas a $4^{\circ} \mathrm{C}$. Os produtos da PCR do sangue dos cães foram examinados por meio da eletroforese em gel de poliacrilamida a $6 \%$, 150 volts, 75Amp, por 90 minutos, fixado com solução de ácido acético e corado com solução de prata a $0,2 \%$, de acordo com protocolos padronizados pelo laboratório de leishmanioses do NMT/UnB. O marcador de peso molecular utilizado nos géis foi o 25 bp ladder (Invitrogen/Life Technologies) com 13 fragmentos entre 25 e 450 pb em múltiplos de 25 pb mais um fragmento de $500 \mathrm{pb}$., sendo considerados positivos aqueles que apresentassem bandas de peso molecular de $800 \mathrm{pb}$.

Nas reações do DNA extraído a partir das amostras dos mamíferos silvestres foi utilizado como controle positivo DNA extraído de amostra sanguínea de cão $\beta$-actina positivo, e como controle negativo foi utilizado água deionizada purificada em sistema Milli- $Q^{\circledR}$. Os resultados foram visualizados em gel de agarose $1,0 \%$ corado com brometo de etídio e examinado em exposição à luz ultravioleta (UV), sendo considerados positivos aqueles que apresentassem bandas de peso molecular de $800 \mathrm{pb}$.

\subsubsection{PCR dirigida ao kDNA de Leishmania spp.}

A amplificação do DNA foi realizada com iniciadores direcionados à região conservada do minicírculo de kDNA de Leishmania spp. com 120 pares de bases (pb): BW-B: 5' CCG CCC CTA TTT TAC ACC AAC CCC 3'; FW: 5' GGG GAG GGG CGT TCT GCG AA 3'; BW-CA: 5' GGC CCA CTA TAT TAC ACC AAC CCC 3' (Carranza-Tamayo, 2010).

As reações foram preparadas em um volume final de $25 \mu \mathrm{l}$, contendo $0,48 \mu \mathrm{M}$ de cada iniciador, tampão de enzima $1 \mathrm{X}, 0,2 \mu \mathrm{M}$ de desoxirribonucleotídeos trifosfato (dNTPs), 2,0 mM de Cloreto de Magnésio 
(MgCl2), 1,5 unidades de Taq DNA polimerase (Invitrogen, Life Technologies, Brasil ) e 20ng (5 $\mu \mathrm{L})$ de DNA.

As reações foram realizadas em Termociclador TC-Plus (Techne, Inglaterra, UK), utilizando as seguintes condições: desnaturação inicial a $95^{\circ} \mathrm{C}$ por 5 minutos, 30 ciclos de desnaturação a $95^{\circ} \mathrm{C}$ por 30 segundos, pareamento a $63^{\circ} \mathrm{C}$ por 30 segundos, seguido de extensão a $75^{\circ} \mathrm{C}$ por 30 segundos e uma extensão final de $72^{\circ} \mathrm{C}$ por 5 minutos. As amostras foram mantidas a $4^{\circ} \mathrm{C}$.

Os controles positivos utilizados nas reações da PCR foram obtidos a partir do isolamento do DNA de culturas em crescimento exponencial de $L$. infantum (MCER/BR/79/M6445), L. amazonensis (IFLA/BR/67/PH8) e $L$. braziliensis (MHOM/BR/75/M2904). E como controle negativo foi utilizado água deionizada purificada em sistema Milli-Q.

Os produtos da PCR foram examinados por meio da eletroforese em gel de poliacrilamida a $6 \%, 150$ volts, $75 \mathrm{Amp}$, por 90 minutos, fixado com solução de ácido acético e corado com solução de prata a 0,2\%, de acordo com protocolos padronizados pelo laboratório de leishmanioses do NMT/UnB.

O marcador de peso molecular utilizado nos géis foi o $25 \mathrm{bp}$ ladder (Invitrogen/Life Technologies) com 13 fragmentos entre 25 e $450 \mathrm{pb}$ em múltiplos de $25 \mathrm{pb}$ mais um fragmento de 500 pb., sendo considerados positivos aqueles que apresentassem bandas de peso molecular de 120pb. 


\section{$\begin{array}{lllllll}\text { 4.6.3.7 PCR dirigida ao gene } 24 S \alpha & \text { rRNA de }\end{array}$ tripanossomatídeos}

Uma estratégia de PCR tendo como alvo a amplificação da região polimórfica do D7 do gene 24Sa rRNA, utilizando como iniciadores os oligonucleotídeos D75 GCAGATCTTGGTTGGCGTAG (posição 01-20) e D76 GGTTCTCTGTTGCCCCTTTT (posição 279-298) que correspondem a sequências conservadas dos genomas de tripanossomatídeos, com fragmento de $\sim 225$ pb sugestivo de Leishmania spp. (Briones et al., 1999; Souto et al., 1999).

As reações foram preparadas em um volume final de $25 \mu \mathrm{l}$, contendo $0,2 \mu \mathrm{M}$ de cada iniciador, $0,2 \mu \mathrm{M}$ de desoxirribonucleotídeos trifosfato (dNTPs), 1,5mM MgCl2, tampão de enzima 1X e 1,5 unidades de Platinum Taq DNA polimerase (Invitrogen, Life Technologies, Brasil ) e $\sim 20 n g(5 \mu \mathrm{L})$ de DNA.

As reações foram realizadas em Termociclador TC-Plus (Techne, Inglaterra, UK) e a amplificação consistiu de uma desnaturação inicial de 3 minutos a $94^{\circ} \mathrm{C}$ seguida por uma PCR com cinco graus "touch-down", variando de 60 a $52^{\circ} \mathrm{C}$, com quatro rodadas de três ciclos, cada um consistindo de 1 minuto a $94^{\circ} \mathrm{C}, 1$ minuto de anelamento a $60,58,56$ e $54^{\circ} \mathrm{C}$, da primeira para a quarta rodada, respectivamente, e 1 minuto de extensão $72^{\circ} \mathrm{C}$. A quinta rodada consistiu de 35 ciclos de 1 minuto a $94^{\circ} \mathrm{C}, 1$ minuto a $52^{\circ} \mathrm{C}$ e 1 minuto a $72^{\circ} \mathrm{C}$. A etapa extensão final a $72^{\circ} \mathrm{C}$ durante 10 minutos terminou o programa (Schijman et al., 2006). As reações foram mantidas a $4^{\circ} \mathrm{C}$ até o uso.

Os controles positivos utilizados nas reações da PCR foram obtidos a partir do isolamento do DNA de culturas em crescimento exponencial de $T$. cruzi (LMPDC/Berenice), $\quad T$. rangeli (SC-58) e $L$. infantum 
(MCER/BR/79/M6445). E como controle negativo foi utilizado água deionizada purificada em sistema Milli-Q.

Os produtos da PCR foram examinados por meio da eletroforese em gel de poliacrilamida a $6 \%, 150$ volts, $75 \mathrm{Amp}$, por 90 minutos, fixado com solução de ácido acético e corado com solução de prata a 0,2\%, de acordo com protocolos padronizados pelo laboratório de leishmanioses do NMT/UnB e em gel de agarose a 1,3\%, corados com brometo de etídio e examinados em exposição à luz ultravioleta (UV).

O marcador de peso molecular utilizado nos géis foi o 25 bp ladder (Invitrogen/Life Technologies) com 13 fragmentos entre 25 e $450 \mathrm{pb}$ em múltiplos de $25 \mathrm{pb}$ mais um fragmento de 500 pb., sendo considerados positivos aqueles que apresentassem bandas de peso molecular de $225 \mathrm{pb}$. Os testes foram feitos em triplicata.

Os fragmentos amplificados foram excisados do gel de agarose e purificados por meio do kit Illustra GFX PCR DNA \& Gel Band Purification Kit (GE Healthcare, New York, USA), para posterior sequenciamento.

\subsubsection{PCR dirigida à região espaçadora interna do DNA ribossômico ITS1 de Leishmania spp.}

Para os animais positivos para Leishmania spp. frente aos oligonucleotídeos D75 e D76 foi realizada a PCR direcionada para a região espaçadora interna do DNA ribossômico (ITS) 1 de Leishmania spp. com fragmento que varia entre 302 e 338pb utilizando os iniciadores LITS1 5' CTG GAT CAT TTT CCG ATG - 3' e L5.85 5' - TGA TAC CAC TTA TCG CAC TT - 3', conforme descrito por Schoönian et al. (2003) e modificado por Tojal da Silva et al. (2006). As reações foram preparadas em um volume final de $25 \mu \mathrm{L}$ utilizando $0,1 \mu \mathrm{M}$ de cada oligonucleotídeo; $0,2 \mu \mathrm{M}$ de 
desoxirribonucleotídeos trifosfato (dNTPs); 2,0 mM de Cloreto de Magnésio (MgCl2); tampão de enzima $1 \mathrm{X} ; 1,5$ unidades de Platinum Taq DNA polimerase (Invitrogen, Life Technologies, Brasil ) e $\sim 20 n g$ (5 $\mu$ L) de DNA.

As reações foram realizadas em Termociclador TC-Plus (Techne, Inglaterra, UK), utilizando as seguintes condições: desnaturação inicial a $95^{\circ} \mathrm{C}$ por 5 minutos, 35 ciclos de desnaturação a $95^{\circ} \mathrm{C}$ por 30 segundos, pareamento a $58^{\circ} \mathrm{C}$ por 30 segundos, seguido de extensão a $72^{\circ} \mathrm{C}$ por 30 segundos e uma extensão final de $72^{\circ} \mathrm{C}$ por 5 minutos. Para aumentar a sensibilidade da reação, os produtos obtidos na primeira reação foram submetidos a uma segunda PCR com os mesmos iniciadores e mesmas condições.

Os controles positivos utilizados nas reações da PCR foram obtidos a partir do isolamento do DNA de culturas em crescimento exponencial de $L$. infantum (MCER/BR/79/M6445), L. amazonensis (IFLA/BR/67/PH8) e $L$. braziliensis (MHOM/BR/75/M2904). E como controle negativo foi utilizado água deionizada purificada em sistema Milli-Q. A especificidade dos iniciadores foi testada com DNA extraído de roedor não infectado proveniente do alojamento dos animais da Faculdade de Medicina/UnB.

Após a reação da PCR realizou-se o diagnóstico molecular dos fragmentos amplificados com bandas de peso molecular de tamanhos entre 302 e 338pb por meio da eletroforese em gel de poliacrilamida a $6 \%$ e em gel de agarose a $1,3 \%$, corados com brometo de etídio e examinados em exposição à luz ultravioleta (UV). Os testes foram feitos em triplicata.

Os fragmentos amplificados foram excisados do gel de agarose e purificados por meio do kit Illustra GFX PCR DNA \& Gel Band Purification Kit (GE Healthcare, New York, USA), para posterior sequenciamento. 


\subsubsection{Preparação dos produtos da PCR para sequenciamento}

Os fragmentos amplificados para a região ITS1 que apresentaram bandas de peso molecular entre 302 e 338pb, assim como os produtos da PCR com alvo na região polimórfica do D7 do gene 24Sa rRNA que apresentaram bandas de aproximadamente $225 \mathrm{pb}$, foram excisados do gel de agarose $1 \%$ e purificados utilizando o kit Illustra GFX PCR DNA \& Gel Band Purification Kit (GE Healthcare, New York, USA), seguindo os procedimentos recomendados pelo fabricante. Os produtos purificados foram quantificados no aparelho Nanovue ${ }^{\mathrm{TM}}$ Plus Spectrophotometer (GE Healthcare, EUA) e em seguida foi realizada a eletroforese em gel de agarose das amostras purificadas para foto.

Os produtos de PCR purificados e diluídos na concentração mínima de 4,0 ng/ul de $\mathrm{H}_{2} \mathrm{O}$ foram enviados para Genomic Engenharia Molecular (São Paulo/SP), juntamente com $5 \mu \mathrm{l}$ do primer de sequenciamento na concentração de $3.2 \mu \mathrm{M}$.

\subsubsection{Sequenciamento e análise das sequências}

As reações de sequenciamento para identificação das espécies de Leishmania foram realizadas pela empresa Genomic Engenharia Molecular utilizando o BigDye ${ }^{\circledR}$ Terminator v3.1 Cycle Sequencing Kit da Applied Biosystems. Os produtos de sequenciamento foram submetidos à eletroforese em um sequenciador modelo 3130xl da Applied Biosystems.

As sequências obtidas foram editadas usando o programa Geneious (Biomatters, New Zealand). Posteriormente, as sequências foram comparadas com sequências de espécies de Leishmania depositadas no GenBank usando o algoritmo BLAST (Basic Local Alignment Search Tool) do 
Centro Nacional para Informação Biotecnológica dos Estados Unidos da América (http://www.ncbi.nlm.nih.gov/BLAST).

\subsection{Análise estatística}

O teste exato de Fisher e o qui-quadrado foram usados para comparar a proporção de indivíduos infectados entre as duas áreas amostradas (PNB e REBIO) e entre as espécies de mamíferos (Excel 2010). As diferenças foram consideradas estatisticamente significativas quando $p<0,05$. 


\section{RESULTADOS}

\subsection{Riqueza e abundância de mamíferos silvestres no PNB e REBIO}

Com um esforço de captura de 5.840 armadilhas-noite, foram amostrados 183 indivíduos, distribuídos em doze espécies de mamíferos silvestres. Na Rebio da Contagem, o esforço de captura foi de 3.360 armadilhas-noite (168X20) e foram amostrados 86 indivíduos referentes a 11 espécies (Tabela 2 e Figuras 11 e 12). No Parque Nacional de Brasília, o esforço de captura foi de 2.480 armadilhas-noite (155X16) e foram amostrados 97 indivíduos de oito espécies (Tabela 2 e Figuras 11 e 12).

A proporção de ocorrência dos indivíduos de cada uma das espécies capturadas nas duas unidades de conservação e nas diferentes fitofisionomias encontra-se na Tabela 2. Necromys lasiurus foi a espécie mais abundante no cerrado da Rebio e no campo de murundu do PNB. Rhipidomys macrurus e Gracilinanus agilis foram as espécies mais abundantes na mata de galeria da Rebio, enquanto $G$. agilis foi a espécie mais abundante na mata de galeria do PNB. As outras nove espécies foram capturadas em proporções menores que $20 \%$ e algumas foram encontradas com exclusividade em uma ou outra área (Tabela 2).

Dos 97 indivíduos capturados no PNB, 36 eram fêmeas e 61 eram machos; 57 haviam atingido a fase reprodutiva e 40 ainda não eram reprodutivos. Dos 86 indivíduos capturados na Rebio, 34 eram fêmeas e 52 eram machos; 48 eram reprodutivos e 38 não reprodutivos. 
Tabela 2. Mamíferos silvestres capturados na Reserva Biológica da Contagem e no Parque Nacional de Brasília entre novembro de 2011 e julho de 2012.

\begin{tabular}{|c|c|c|c|c|c|c|c|c|c|c|c|}
\hline \multirow[b]{3}{*}{ Família } & \multirow[b]{3}{*}{ Espécie } & \multicolumn{5}{|c|}{ Rebio } & \multicolumn{5}{|c|}{ PNB } \\
\hline & & \multirow{2}{*}{$\begin{array}{c}\text { Total } \\
\mathrm{NI}\end{array}$} & \multicolumn{2}{|c|}{ Mata } & \multicolumn{2}{|c|}{ Cerrado } & \multirow{2}{*}{$\begin{array}{c}\text { Total } \\
\mathrm{NI}\end{array}$} & \multicolumn{2}{|c|}{ Mata } & \multicolumn{2}{|c|}{ Campo } \\
\hline & & & $\mathrm{NI}$ & $\%$ & $\mathrm{NI}$ & $\%$ & & $\mathrm{NI}$ & $\%$ & $\mathrm{NI}$ & $\%$ \\
\hline \multirow[t]{8}{*}{ Cricetidae } & Calomys sp. & 1 & 1 & 1,6 & 0 & 0 & 8 & 2 & 12 & 6 & 7,5 \\
\hline & Cerradomys scotti & 2 & 0 & 0 & 2 & 8,2 & 0 & 0 & 0 & 0 & 0 \\
\hline & Necromys lasiurus & 20 & 2 & 3,2 & 18 & 75 & 70 & 0 & 0 & 70 & 87,5 \\
\hline & Nectomys rattus & 8 & 8 & 13 & 0 & 0 & 2 & 2 & 12 & 0 & 0 \\
\hline & Oecomys bicolor & 6 & 5 & 8,1 & 1 & 4,2 & 0 & 0 & 0 & 0 & 0 \\
\hline & Oecomys catherinae & 1 & 1 & 1,6 & 0 & 0 & 0 & 0 & 0 & 0 & 0 \\
\hline & Rhipidomys macrurus & 25 & 25 & 40,3 & 0 & 0 & 1 & 1 & 6 & 0 & 0 \\
\hline & Thalpomys lasiotis & 2 & 1 & 1,6 & 1 & 4,2 & 2 & 0 & 0 & 2 & 2,5 \\
\hline \multirow[t]{2}{*}{ Didelphidae } & Didelphis albiventris & 3 & 2 & 3,2 & 1 & 4,2 & 3 & 3 & 17 & 0 & 0 \\
\hline & Gracilinanus agilis & 17 & 17 & 27,4 & 0 & 0 & 9 & 9 & 53 & 0 & 0 \\
\hline Echimyidae & Clyomys laticeps & 0 & 0 & 0 & 0 & 0 & 2 & 0 & 0 & 2 & 2,5 \\
\hline \multirow[t]{2}{*}{ Procyonidae } & Nasua nasua & 1 & 0 & 0 & 1 & 4,2 & 0 & 0 & 0 & 0 & 0 \\
\hline & Total & 86 & 62 & 100 & 24 & 100 & 97 & 17 & 100 & 80 & 100 \\
\hline
\end{tabular}

NI - número de indivíduos; \% - proporção do número de indivíduos capturados por espécie em cada unidade de conservação. 

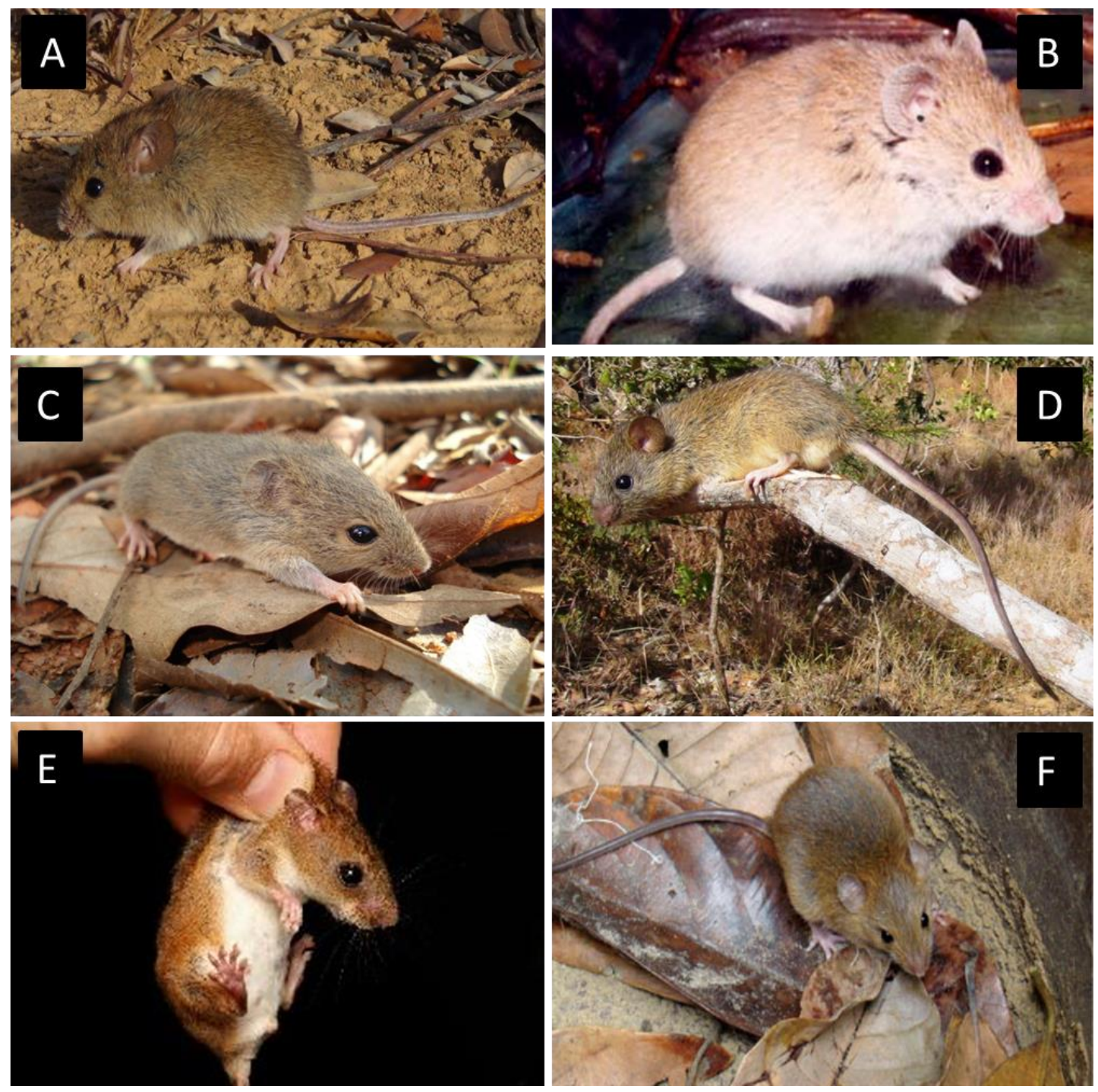

Figura 11. Espécies de roedores pertencentes à família Cricetidae e subfamília Sigmodontinae: (A) Calomys sp., (B) Thalpomys lasiotis, (C) Necromys lasiurus, (D) Cerradomys scotti, (E) Oecomys bicolor e (F) Oecomys catherinae. Fontes: Marcelo Reis (A e D); Bonvicino et al, 2008 (B); Juliana Bragança (C); http://www.boldsystems.org (E) e Asfora et al. 2011 (F). 

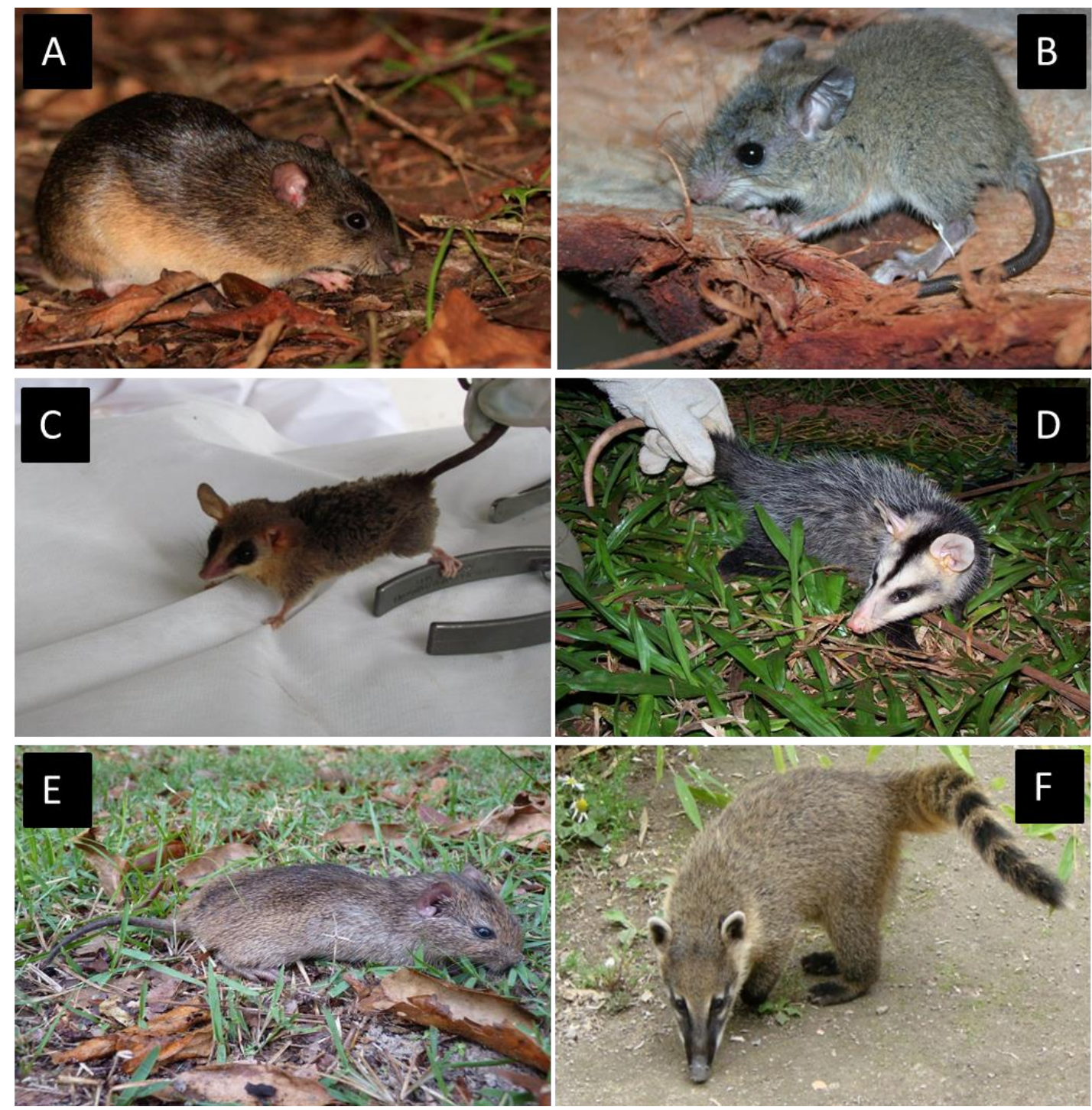

Figura 12. Espécies de roedores pertencentes à família Cricetidae e subfamília Sigmodontinae: (A) Nectomys rattus e (B) Rhipidomys macrurus; marsupiais da família Didelphidae (C) Gracilinanus agilis e (D) Didelphis albiventris; (E) Clyomys laticeps, roedor pertencente à família Echimyidae; e (F) Nasua nasua, carnívoro da família Procyonidae. Fontes: http://www.planet-mammiferes.org (A e E); Juliana Bragança (B); http://www.faunaparaguay.com (D) e http://en.wikipedia.org (F). 


\subsection{Detecção molecular de Leishmania spp. nos mamíferos silvestres}

Foi coletado fragmento de pele de todos os 183 indivíduos de mamíferos silvestres, porém, amostras de pele de 20 indivíduos não passaram no controle endógeno da qualidade e integridade do DNA, sendo descartadas da pesquisa. Desses 20 indivíduos, quatro não possuíam amostras de sangue, já que não foi possível essa coleta em todos os animais capturados. Portanto, foram estudados 179 indivíduos, sendo 84 da Rebio e 95 do PNB.

No total foram analisados 163 fragmentos de pele, sendo 77 de indivíduos da Rebio e 86 do PNB, e 154 amostras de sangue, sendo 76 de indivíduos da Rebio e 78 do PNB.

Dos 179 indivíduos estudados, 20,1\% ( $n=36)$ tiveram amostras positivas para o gene 24Sa rRNA, apresentando um fragmento de aproximadamente $225 \mathrm{pb}$, sugestivo para Leishmania spp. (Figura 13), e $4,5 \%(n=8)$ tiveram amostras positivas para os iniciadores ITS1 (Figura 14), confirmando a presença de Leishmania spp. (Tabela 3). As espécies que apresentaram amostras positivas para o gene 24Sa rRNA foram Clyomys laticeps, Gracilinanus agilis, Necromys lasiurus, Nectomys rattus, Rhipidomys macrurus e Didelphis albiventris (Tabela 3).

A espécie mais abundante nas duas unidades de conservação, Necromys lasiurus ( $n=90)$, teve $20 \%$ (18/90) das amostras positivas para 0 gene 24Sa rRNA, com fragmento sugestivo para Leishmania spp., e 3,3\% (3/90) das amostras positivas para o ITS1. R. macrurus e G. agilis tiveram $27 \%(7 / 26)$ e $28 \%$ (7/25), respectivamente, das amostras positivas para 24Sa rRNA, com fragmento sugestivo para Leishmania spp., e 3,9\% (1/26) e 12\% (3/25) de positivas para ITS1 (Tabela 3).

Dos 36 indivíduos que tiveram amostras positivas para 24Sa rRNA, 
22 eram machos e 14 eram fêmeas; 26 (105) eram reprodutivos e 10 (78) não reprodutivos. Enquanto dos oito animais positivos para (ITS)1, quatro eram machos e quatro eram fêmeas; cinco eram reprodutivos e três eram não reprodutivos.

Dos 36 indivíduos que tiveram amostras positivas para o gene 24Sa rRNA, 32 foram positivos no DNA extraído da pele e 7 no DNA extraído do sangue de papel filtro (Tabela 4), sendo 3 indivíduos positivos em ambas as amostras (pele e sangue): um Necromys lasiurus, um Gracilinanus agilis e um Rhipidomys macrurus. Dos oito indivíduos que tiveram amostras positivas para o (ITS) 1, 7 foram positivos no DNA extraído da pele e um no DNA extraído do sangue de papel filtro (Tabela 4). Nenhum indivíduo foi positivo para (ITS)1 nas duas amostras (pele e sangue). Dos seis Didelphis albiventris capturados, $50 \%$ não passou no controle de qualidade da extração do DNA da pele e apenas um indivíduo foi positivo para gene $24 \mathrm{Sa}$ rRNA, em amostra de sangue.

Não foram observadas diferenças significativas comparando a proporção de indivíduos infectados por Leishmania spp. entre as duas áreas amostradas e entre as espécies ( $p>0.05)$. 


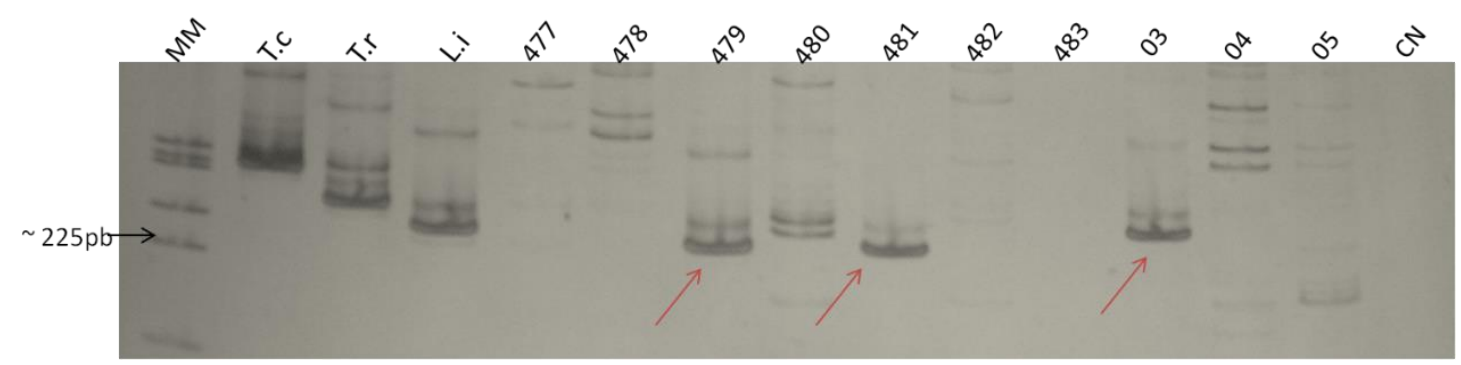

Figura 13. Gel de poliacrilamida a $6 \%$ mostrando resultado da PCR direcionada ao gene 24Sa rRNA, com fragmento aproximado de 225 pb sugestivo para Leishmania spp., de amostras de mamíferos silvestres. MM: marcador de peso molecular; Controles positivos: T. cruzi-T.c, T. rangeli-T.r e L. infantum-L.i; Controle negativo: $\mathrm{CN}$. As setas vermelhas indicam os produtos amplificados com tamanho esperado.

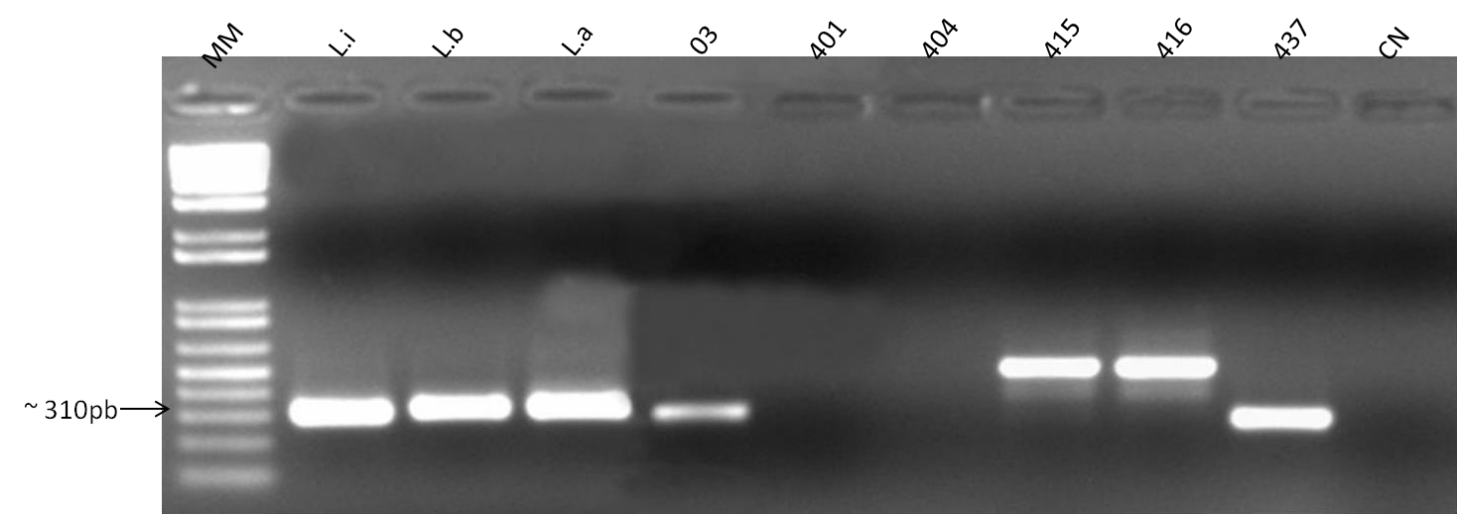

Figura 14. Gel de agarose a 1,3\% mostrando resultado da PCR direcionada ao ITS1, com as amostras de mamíferos silvestres $n^{\circ s} 03$ e 437 apresentando fragmento de aproximadamente $310 \mathrm{pb}$, sugestivo para Leishmania spp., e as amostras $n^{\circ s} 415$ e 416 apresentando fragmento de aproximadamente $500 \mathrm{pb}$, sugestivo para outros tripanossomatídeos. MM: marcador de peso molecular; Controles positivos: L. infantum-L.i, L. braziliensis-L.b e L. amazonensis-L.a; Controle negativo: CN. 
Tabela 3. Número de amostras positivas e proporção de mamíferos positivos para o gene 24Sa rRNA de tripanossomatídeos e para o (ITS)1 de Leishmania spp., por espécie e em cada unidade de conservação.

\begin{tabular}{|c|c|c|c|c|c|c|c|c|c|c|c|}
\hline \multirow{3}{*}{ Família } & \multirow{3}{*}{ Espécies } & \multicolumn{5}{|c|}{ Rebio } & \multicolumn{5}{|c|}{ PNB } \\
\hline & & \multirow[t]{2}{*}{ NIE } & \multicolumn{2}{|c|}{ 24Sa rRNA } & \multicolumn{2}{|c|}{ ITS1 } & \multirow[t]{2}{*}{ NIE } & \multicolumn{2}{|c|}{ 24Sa rRNA } & \multicolumn{2}{|c|}{ ITS1 } \\
\hline & & & NA & $\%$ & NA & $\%$ & & NA & $\%$ & NA & $\%$ \\
\hline \multirow[t]{7}{*}{ Cricetidae } & Calomys sp. & 1 & 0 & 0 & 0 & 0 & 6 & 0 & 0 & 0 & 0 \\
\hline & Cerradomys scotti & 2 & 0 & 0 & 0 & 0 & 0 & 0 & 0 & 0 & 0 \\
\hline & Necromys lasiurus & 20 & 6 & 30 & 1 & 5 & 70 & 12 & 17,1 & 2 & 2,9 \\
\hline & Nectomys rattus & 8 & 2 & 25 & 1 & 12,5 & 2 & 0 & 0 & 0 & 0 \\
\hline & Oecomys bicolor & 6 & 0 & 0 & 0 & 0 & 0 & 0 & 0 & 0 & 0 \\
\hline & Rhipidomys macrurus & 25 & 7 & 28 & 1 & 4 & 1 & 0 & 0 & 0 & 0 \\
\hline & Thalpomys lasiotis & 2 & 0 & 0 & 0 & 0 & 2 & 0 & 0 & 0 & 0 \\
\hline \multirow[t]{2}{*}{ Didelphidae } & Didelphis albiventris & 3 & 1 & 33,3 & 0 & 0 & 3 & 0 & 0 & 0 & 0 \\
\hline & Gracilinanus agilis & 16 & 5 & 31,3 & 2 & 12,5 & 9 & 2 & 22,2 & 1 & 11,1 \\
\hline Echimyidae & Clyomys laticeps & 0 & 0 & 0 & 0 & 0 & 2 & 1 & 50 & 0 & 0 \\
\hline \multirow[t]{2}{*}{ Procyonidae } & Nasua nasua & 1 & 0 & 0 & 0 & 0 & 0 & 0 & 0 & 0 & 0 \\
\hline & Total & 84 & 21 & 25 & 5 & 6 & 95 & 15 & 15,8 & 3 & 3,2 \\
\hline
\end{tabular}

NA - Números absolutos das amostras positivas; NIE - número de indivíduos estudados. 
Tabela 4. Número de amostras de pele e de sangue positivas para o gene 24Sa rRNA apresentando fragmento de $\sim 225$ pb, sugestivo para Leishmania spp., e para o ITS1, apresentando fragmento de $\sim 330 \mathrm{pb}$, por espécie e em cada unidade de conservação.

\begin{tabular}{lcccccccc}
\hline & \multicolumn{2}{c}{$\begin{array}{c}\text { 24Sa rRNA } \\
\text { Pele }\end{array}$} & \multicolumn{2}{c}{$\begin{array}{c}\text { 24Sa rRNA } \\
\text { Sangue }\end{array}$} & \multicolumn{2}{c}{$\begin{array}{c}\text { ITS1 } \\
\text { Pele }\end{array}$} & \multicolumn{2}{c}{$\begin{array}{c}\text { ITS1 } \\
\text { Sangue }\end{array}$} \\
\cline { 2 - 9 } & PNB & Rebio & PNB & Rebio & PNB & Rebio & PNB & Rebio \\
\hline Clyomys laticeps & 1 & 0 & 0 & 0 & 0 & 0 & 0 & 0 \\
Didelphis albiventris & 0 & 0 & 0 & 1 & 0 & 0 & 0 & 0 \\
Gracilinanus agilis & 2 & 4 & 1 & 1 & 1 & 1 & 0 & 1 \\
Necromys lasiurus & 10 & 6 & 3 & 0 & 2 & 1 & 0 & 0 \\
Nectomys rattus & 0 & 2 & 0 & 0 & 0 & 1 & 0 & 0 \\
Rhipidomys macrurus & 0 & 7 & 0 & 1 & 0 & 1 & 0 & 0 \\
\hline Total & 13 & 19 & 4 & 3 & 3 & 4 & 0 & 1 \\
\hline
\end{tabular}

\subsection{Detecção molecular de Leishmania spp. nos cães}

\section{domésticos}

O presente estudo avaliou 19 cães, dos quais, 12 (63\%) eram machos e sete (37\%) eram fêmeas. Um dos cães era originário de Minas Gerais, um de Goiás e outro de Pernambuco, os demais eram de origem do Distrito Federal. Todos os indivíduos eram criados soltos nos quintais das casas, com livre acesso ao interior das residências, porém, não tinham acesso às ruas do condomínio. Dos cães estudados, 11 (58\%) usavam coleira impregnada com inseticida e 10 (53\%) foram vacinados contra LV. Dos 19 cães, quatro (21\%) apresentaram algum tipo de sinal clínico inespecífico, como emagrecimento, onicogrifose ou lesões cutâneas (Tabela 5).

As amostras dos cães foram todas positivas ao teste DPP. A amplificação da região conservada de kDNA foi positiva para três $(15,8 \%)$ cães (Figura 15). A PCR com alvo na amplificação da região polimórfica do D7 do gene 24Sa rRNA, com fragmento de $225 \mathrm{pb}$ sugestivo para Leishmania spp., foi positiva para três $(15,8 \%)$ cães e a PCR direcionada à região espaçadora interna do DNA ribossômico (ITS)-1 confirmou os três 
cães positivos no alvo 24Sa rRNA (Figura 16). Duas das amostras positivas na PCR-kDNA (cães nos 10 e 15) foram negativas na PCR-ITS1 e PCR-24Sa rRNA e duas das amostras positivas na PCR-ITS1 e na PCR-24Sa rRNA (cães $n^{\circ 5} 2$ e 7) foram negativas na PCR-kDNA. Apenas a amostra do cão $n^{\circ}$ 11 foi positiva para os três marcadores. No total, cinco amostras de cães $(26,3 \%)$ foram positivas nos testes moleculares. O controle endógeno de $\beta$ actina evidenciou a qualidade do DNA nas amostras. Os resultados estão agrupados na Tabela 5.

Tabela 5. Características dos cães amostrados residentes em área endêmica de leishmaniose visceral e tegumentar e resultados da infecção por Leishmania spp. Brasília, Distrito Federal, 2013.

\begin{tabular}{ccccccccc}
\hline Cão & $\begin{array}{c}\text { Idade } \\
\text { (anos) }\end{array}$ & Sexo & $\begin{array}{c}\text { Sinais } \\
\text { clínicos }\end{array}$ & Vacinação & $\begin{array}{c}\text { Uso de } \\
\text { coleira }\end{array}$ & kDNA & 24Sa & ITS1 \\
\hline 1 & 5 & $\mathrm{M}$ & Não & Não & Sim & - & - & - \\
2 & 11 & $\mathrm{M}$ & Sim & Não & Não & - & + & + \\
3 & 8 & $\mathrm{M}$ & Sim & Não & Não & - & - & - \\
4 & 14 & $\mathrm{~F}$ & Não & Sim & Sim & - & - & - \\
5 & 5 & $\mathrm{~F}$ & Não & Sim & Sim & - & - & - \\
6 & 5 & $\mathrm{~F}$ & Não & Sim & Sim & - & - & - \\
7 & 5 & $\mathrm{M}$ & Não & Sim & Não & - & + & + \\
8 & NI & $\mathrm{F}$ & Sim & Não & Não & - & - & - \\
9 & 14 & $\mathrm{~F}$ & Não & Sim & Sim & - & - & - \\
10 & 11 & $\mathrm{M}$ & Não & Sim & Não & + & - & - \\
11 & 4 & $\mathrm{M}$ & Sim & Não & Não & + & + & + \\
12 & 7 & $\mathrm{M}$ & Não & Não & Sim & - & - & - \\
13 & 2 & $\mathrm{~F}$ & Não & Sim & Sim & - & - & - \\
14 & 3 & $\mathrm{M}$ & Não & Não & Sim & - & - & - \\
15 & 6 & $\mathrm{M}$ & Não & Não & Não & + & - & - \\
16 & 8 & $M$ & Não & Sim & Sim & NR & - & - \\
17 & 5 & $\mathrm{~F}$ & Não & Sim & Sim & NR & - & - \\
18 & 5 & $M$ & Não & Sim & Não & NR & - & - \\
19 & 1 & $M$ & Não & Não & Sim & NR & - & - \\
\hline
\end{tabular}

${ }^{*}$ TR DPP® Leishmaniose Visceral Canina Bio-Manguinhos; NR: não realizado; NI: não informado. 


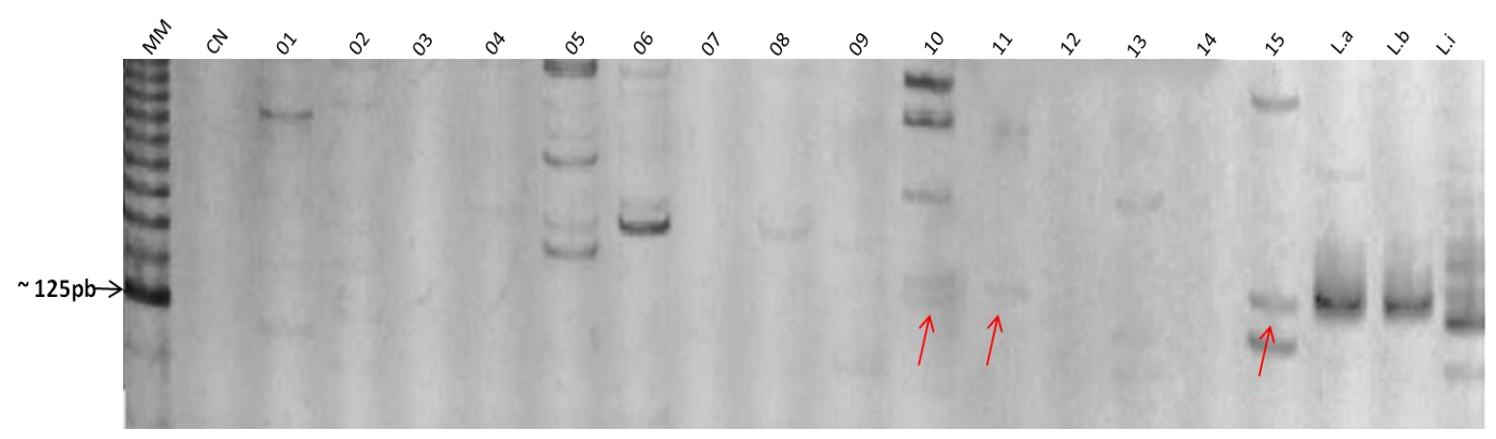

Figura 15. Gel de poliacrilamida a $6 \%$ mostrando resultado da PCR direcionada para a região conservada de $\mathrm{kDNA}(120 \mathrm{pb})$, com marcador de peso molecular $(\mathrm{MM})$, controle negativo $(\mathrm{CN})$, amostras caninas 1 a 15 e controles positivos ( $L$. infantum, L. braziliensis e $L$. amazonensis). As setas vermelhas indicam os produtos amplificados com tamanho esperado.

A

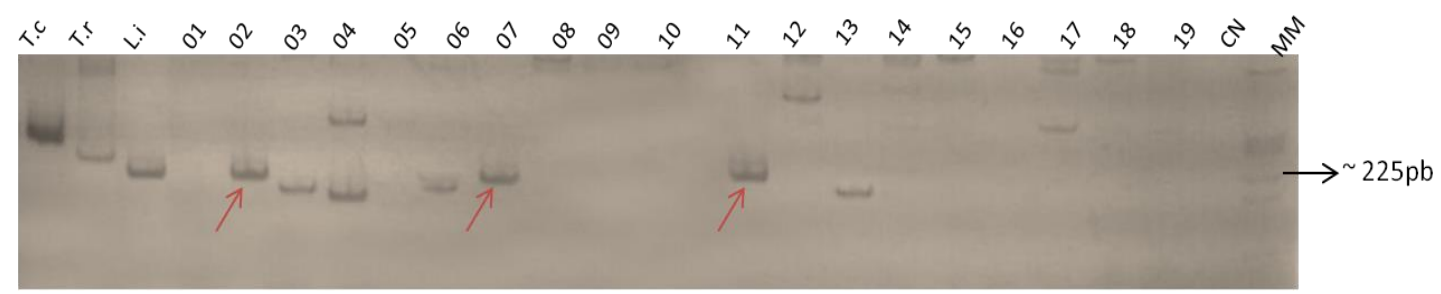

B

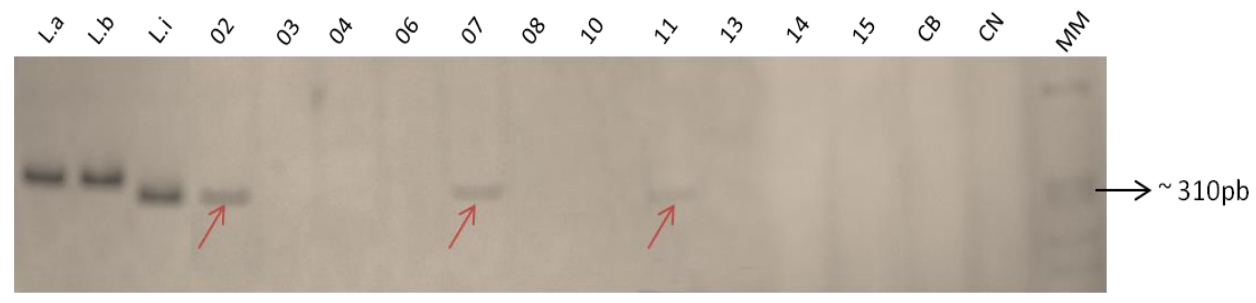

Figura 16. Gel de poliacrilamida a $6 \%$ mostrando resultado da PCR (A) direcionada ao gene 24Sa rRNA, com fragmento aproximado de 225 pb sugestivo para Leishmania spp., das amostras caninas 1 a 19, e (B) ao ITS1, como fragmento de aproximadamente $310 \mathrm{pb}$, das amostras caninas que apresentaram bandas com os iniciadores D75 e D76. MW: marcador de peso molecular; Controles positivos: T. cruzi-T.c, T. rangeli-T.r, L. infantum-L.i, L. braziliensis-L.b e L. amazonensis-L.a; Controle negativo: NC; WC: Controles brancos. As setas vermelhas indicam os produtos amplificados com tamanho esperado. 


\subsection{Detecção de outros tripanossomatideos nas amostras}

Dos 179 indivíduos estudados, 7,3\% ( $n=13)$ apresentaram em suas amostras fragmento de aproximadamente $240 \mathrm{pb}$ a $290 \mathrm{pb}$ para o gene $24 \mathrm{Sa}$ rRNA, sugerindo positividade para outros tripanossomatídeos, diferentes de Leishmania spp.. Sete apresentaram banda próxima a Trypanosoma rangeli ( 240pb) e seis apresentaram banda próxima a Trypanosoma cruzi ( 270 a 290pb), de acordo com Schijman et al. ( 2006). Dos 13 indivíduos, três foram capturados no PNB, todos da espécie Necromys lasiurus. Os outros dez foram capturados na Rebio e pertencem as espécies Gracilinanus agilis $(\mathrm{n}=3)$, Rhipidomys macrurus $(\mathrm{n}=3)$, Necromys lasiurus $(\mathrm{n}=2)$, Nectomys rattus $(\mathrm{n}=1)$ e Oecomys bicolor $(\mathrm{n}=1)$.

Entretanto, outras quatro amostras que haviam apresentado banda próxima a de Leishmania ( $225 \mathrm{pb})$, foram submetidas a amplificação dirigida a região (ITS) 1 e apresentaram bandas acima do esperado ( 500pb) (Figura 14). Os produtos desta PCR foram sequenciados e identificados como outros tripanossomatídeos (ver item 5.5).

\subsection{Identificação específica das amostras}

O sequenciamento dos produtos da PCR-ITS1 identificou a sequência do DNA extraído da amostra do sangue de dois cães ( $n^{\circ s} 2$ e 7) como Leishmania infantum, com $100 \%$ de identidade (Tabela 6 e Figura 17). $O$ DNA extraído da amostra de pele de um Necromys lasiurus capturado no campo de murundu do PNB de Brasília foi identificado como Leishmania amazonensis, com 100\% de identidade (Tabela 6 e Figura 18) e a sequência do DNA extraído da amostra de pele de um $N$. lasiurus capturado no cerrado da Rebio apresentou $99 \%$ de identidade com sequências de L. braziliensis. O sequenciamento dos produtos da PCR-24Sa rRNA identificou a sequência 
do DNA extraído da pele de dois $R$. macrurus da mata de galeria da Rebio com $89 \%$ de identidade com L. braziliensis (Tabela 6).

Além da identificação de espécies de Leishmania infectando os mamíferos silvestres, foram identificadas sequências de outros tripanossomatídeos de roedores. No sequenciamento dos produtos da PCRITS1, que apresentaram bandas acima do esperado, as sequências do DNA extraído das amostras de pele de dois Necromys lasiurus, capturados no PNB, apresentaram $82 \%$ identidade com Trypanosoma otospermophili e a sequência do DNA extraído de uma amostra de sangue de um $N$. lasiurus, capturado no PNB, apresentou $79 \%$ de identidade também com uma sequencia de $T$. otospermophili, entretando, a análise da sequencia do DNA extraído da amostra de sangue de outro animal da mesma espécie, proveniente da Rebio, foi reconhecida como Trypanosoma lewisi, com 79\% de identidade. No sequenciamento dos produtos da PCR-24Sa rRNA, as sequências do DNA extraído das amostras de pele de três dos mesmos indivíduos de $N$. lasiurus apresentaram entre 98 e 99\% de identidade com $T$. otospermophili e $98 \%$ de identidade com $T$. kuseli e com T. grosi, e a sequência do DNA de um indivíduo de $G$. agilis teve $91 \%$ de identidade com T. grosi no sequenciamento dos produtos da PCR-24Sa rRNA (Tabela 6). 
Tabela 6. Identificação dos indivíduos com informações sobre a espécie, local de captura, tipo de amostra biológica, PCR utilizada, resultado do Blastn, Score, e-value e identidade de cada sequenciamento.

\begin{tabular}{|c|c|c|c|c|c|c|c|c|c|}
\hline Indivíduo & Espécie & Local de captura & Amostra & PCR & Blastn & $\mathrm{N}^{\circ}$ de acesso & Score & e-value & Identidade \\
\hline 2 & Canis familiaris & Cond. Viv. Bela Vista & Sangue & ITS1 & L. infantum & $\mathrm{gb} \mid \mathrm{KC} 347301.1$ & 565 bits $(626)$ & $5 e-160$ & $313 / 313(100 \%)$ \\
\hline 7 & Canis familiaris & Cond. Viv. Bela Vista & Sangue & ITS1 & L. infantum & $\mathrm{gb} \mid \mathrm{KC} 347301.1$ & 567 bits $(628)$ & $2 e-160$ & $314 / 314(100 \%)$ \\
\hline 437 & N. lasiurus & Rebio & Pele & ITS1 & L. braziliensis & $\mathrm{gb} \mid \mathrm{FJ} 753379.1$ & 536 bits(594) & $4 \mathrm{e}-149$ & 300/302(99\%) \\
\hline 523 & N. lasiurus & PNB & Sangue & ITS1 & T. otospermophili & $\mathrm{dbj} \mid \mathrm{AB} 175625.1$ & 329 bits(364) & $2 \mathrm{e}-86$ & $314 / 395(79 \%)$ \\
\hline 404 & N. lasiurus & Rebio & Sangue & ITS1 & T. lewisi & $\mathrm{gb} \mid \mathrm{GU} 252222.1$ & $264 \operatorname{bits}(292)$ & $5 e-67$ & $280 / 356(79 \%)$ \\
\hline 415 & N. lasiurus & PNB & Pele & ITS1 & T. otospermophili & $\mathrm{dbj} \mid \mathrm{AB} 175625.1$ & 295 bits(326) & $3 e-76$ & $270 / 331(82 \%)$ \\
\hline 416 & N. lasiurus & PNB & Pele & ITS1 & T.otospermophili & dbj|AB175625.1 & 297 bits(328) & $9 e-77$ & $270 / 330(82 \%)$ \\
\hline 404 & N. lasiurus & Rebio & Pele & $24 \mathrm{~S} \alpha \mathrm{rRNA}$ & T.otospermophili & dbj|AB190228.1 & 286 bits(316) & $6 e-76$ & $163 / 166(98 \%)$ \\
\hline 415 & N. lasiurus & PNB & Pele & $24 \mathrm{~S} \alpha \mathrm{rRNA}$ & T. otospermophili & dbj|AB190228.1 & 399 bits(442) & $4 \mathrm{e}-110$ & $226 / 229(99 \%)$ \\
\hline 416 & N. lasiurus & $\mathrm{PNB}$ & Pele & $24 \mathrm{~S} \alpha \mathrm{rRNA}$ & T.otospermophili & dbj|AB190228.1 & 401 bits(444) & $1 e-110$ & $227 / 230(99 \%)$ \\
\hline 511 & G. agilis & PNB & Pele & $24 \mathrm{~S} \alpha \mathrm{rRNA}$ & T. grosi & $\mathrm{dbj} \mid \mathrm{AB} 175624.1$ & 221 bits(244) & $2 e-56$ & $145 / 159(91 \%)$ \\
\hline 479 & R. macrurus & Rebio & Pele & $24 \mathrm{~S} \alpha \mathrm{rRNA}$ & L. braziliensis & gb|JX030149.1 & 210 bits(232) & $3 e-53$ & $153 / 171(89 \%)$ \\
\hline
\end{tabular}
Blastn: Basic Local Alignment Search Tool. 
Leishmania infantum strain MHOM/IR/2012/Savodjbolagh13 18S ribosomal RNA gene, partial sequence; internal transcribed spacer 1, complete sequence; and

A $5.8 \mathrm{~S}$ ribosomal RNA gene, partial sequence
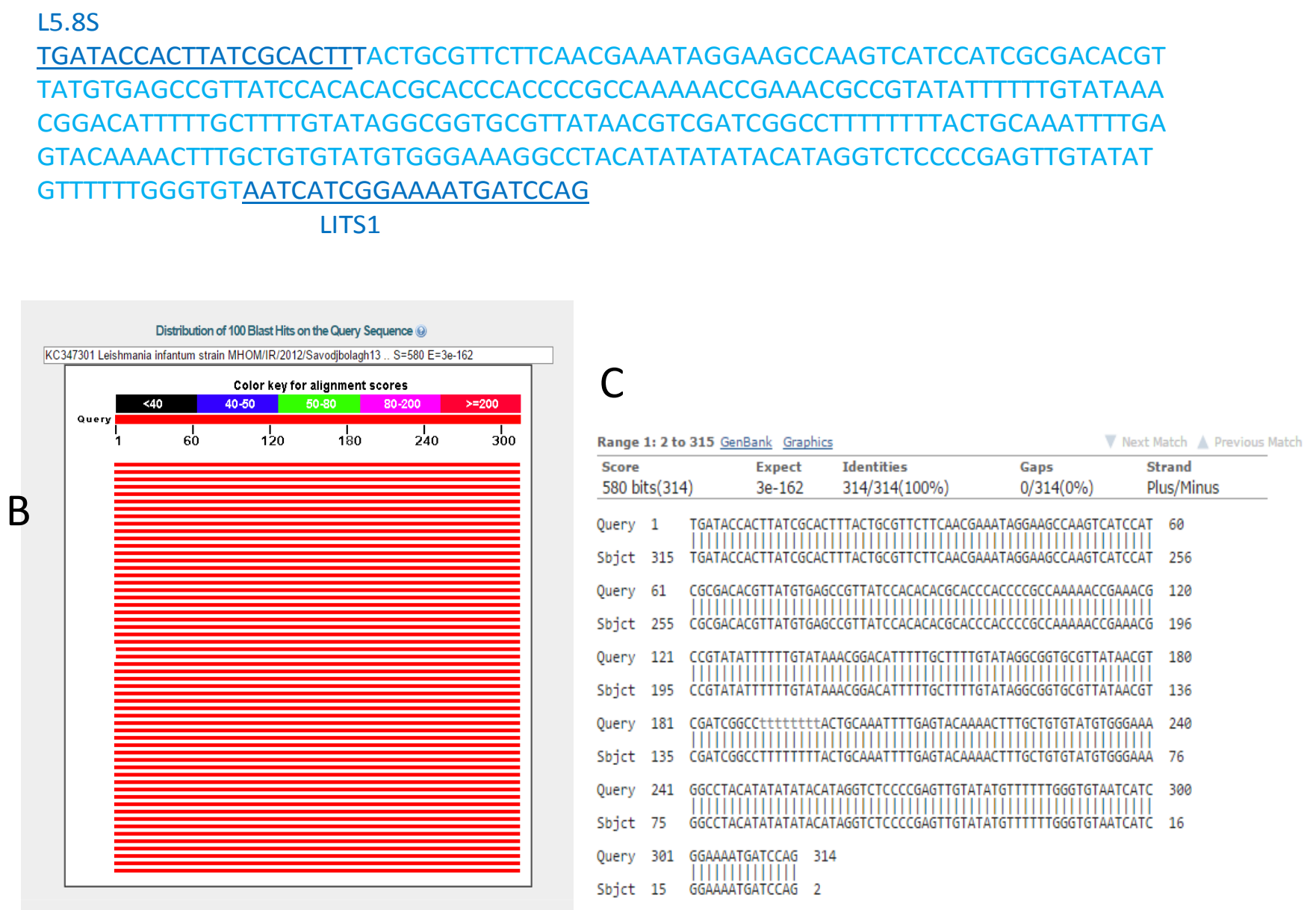

Figura 17. Identificação de DNA de Leishmania infantum em amostra de cão. A) Sequência amplificada na PCR-ITS com 314 pb utilizando o animal 7. Os primers estão sublinhados. B) Gráfico produzido pelo algorítmo BLASTn durante a busca feita no GenBank. C) Alinhamento mostrando 100\% de identidade com sequência de Leishmania infantum do locus KC347301. 


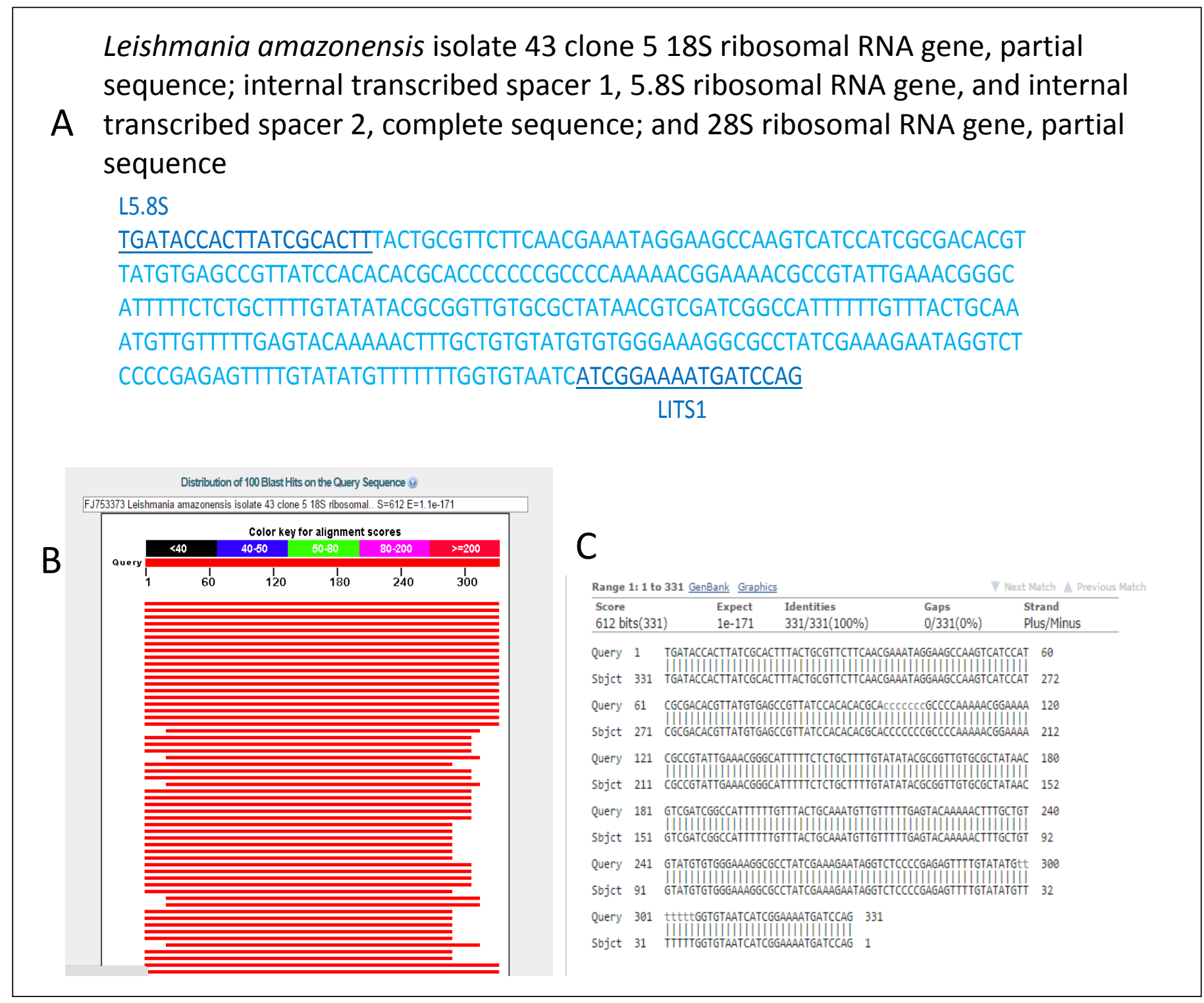

Figura 18. Identificação de DNA de Leishmania amazonensis em amostra de Necromys lasiurus. A) Sequência amplificada na PCR-ITS com 331 pb utilizando amostra do animal 3. Os primers estão sublinhados. B) Gráfico produzido pelo algorítmo BLASTn durante a busca feita no GenBank. C) Alinhamento mostrando $100 \%$ de identidade com sequência de Leishmania amazonensis do locus FJ753373. 


\section{DISCUSSÃO}

O DNA de três espécies de Leishmania foi detectado em mamíferos silvestres das unidades de conservação e em cães domésticos do entorno: $L$. infantum $L$. amazonensis e $L$. braziliensis, sendo que as espécies encontradas infectando os animais silvestres dentro das unidades de conservação ( $L$. amazonensis e $L$. braziliensis) foram diferentes da espécie encontrada infectando os cães domésticos no entorno ( $L$. infantum). Este fato indica a existência de ciclos diferentes e independentes das espécies de Leishmania na região estudada. A ausência de $L$. infantum no ambiente silvestre nos leva a hipótese de que esta espécie tenha sido introduzida na região pela aquisição de cães infectados provenientes de outras áreas endêmicas, uma vez que a LV no Distrito Federal não havia sido registrada até 2005. Porém, a possibilidade de mamíferos silvestres servirem como fonte de infecção para os vetores no peridomicílio não deve ser ignorada (Roque \& Jansen 2014), uma vez que a participação desses mamíferos no ciclo de transmissão de $L$. infantum em áreas urbanas vem sendo proposta (Lainson et al. 1969, Santiago et al. 2007, Carreira et al. 2012, Humberg et al. 2012). Além disso, o esforço de amostragem para os cães foi pequeno e não podemos excluir, no cenário estudado, a possibilidade de $L$. braziliensis ou L. amazonensis circulando na população canina doméstica, conforme relatado em outras áreas endêmicas para estas espécies (Tolezano et al. 2007; Oliveira et al. 2014).

Vários estudos têm demonstrado que os cães têm papel fundamental no ciclo doméstico de $L$. infantum, principalmente pelo grande contigente de cães assintomáticos albergando o parasito na derme, o que favorece a transmissão (Dantas-Torres e Brandao-Filho 2006, Dantas-Torres 2007, 2009). Os mamíferos silvestres, no entanto, favorecem a manutenção do ciclo de $L$. amazonensis e de $L$. braziliensis nas unidades de conservação estudadas. Leishmania amazonensis foi identificada com 100\% de identidade no DNA extraído da amostra de pele de $N$. lasiurus capturado no 
PNB, sendo o primeiro registro nesta espécie de roedor no Brasil Central e também o primeiro registro de $R$. macrurus infectado por uma espécie de Leishmania (L. braziliensis). Até o momento havia apenas o registro de uma espécie de Rhipidomys da mata atlântica ( $R$. mastacalis) infectada com $L$. infantum (Quaresma et al 2011). Os resultados sugerem o envolvimento de pelos menos 6 espécies de gêneros diferentes de mamíferos silvestres no ciclo biológico de Leishmania spp. no DF. Todos os seis gêneros já haviam sido encontrados parasitados por alguma espécie de Leishmania (BrandãoFilho et al. 1994 e 2003, Peterson et al. 1988, Dantas-Torres e BrandaoFilho 2006, Quaresma et al. 2011, Roque \& Jansen 2014).

Dos mamíferos silvestres estudados, 20,1\% tiveram amostras sugestivas para Leishmania spp. considerando o marcador 24Sa rRNA. Apesar de não ter sido detectada diferença significativa na proporção de mamíferos positivos entre as áreas, a Rebio apresentou uma taxa de infecção superior que o PNB. A Rebio tem maior influência antropogênica com o estabelecimento de áreas residenciais em todo seu entorno e com um intenso fluxo de animais domésticos e de pessoas no seu interior. Futuros estudos analisando um maior número de mamíferos e incluindo dados de ocorrência e infecção natural das espécies de flebotomíneos nessas áreas poderão esclarecer o efeito de modificações ambientais na transmissão enzoótica de Leishmania.

A espécie Necromys lasiurus possui ampla distribuição geográfica no Brasil. Habita formações abertas e florestais do Cerrado e Mata Atlântica, além de áreas de vegetação aberta no estado do Pará. Possui hábito terrestre e onívoro, alimentando-se de sementes e insetos (Reis et al. 2006, Bonvicino et al. 2008). É considerada a espécie mais abundante e mais generalista de habitat em todo o Cerrado no Brasil Central (Alho et al. 1986, Marinho-Filho et al. 1994), sendo encontrada em matas de galeria, cerradão, cerrado sensu stricto e em áreas abertas. Neste estudo $N$. lasiurus foi a espécie de mamífero silvestre mais abundante ( $n=90,50,28 \%)$, sendo que a 
proporção de indivíduos capturados dessa espécie foi maior no cerrado sensu stricto da Rebio ( $n=18,75 \%$ ) e no campo de murundu do PNB ( $n=70$, $87,5 \%$ ). Apenas dois indivíduos de $N$. lasiurus foram capturados na mata de galeria da Rebio e nenhum indivíduo na mata do PNB. Apesar de N. lasiurus utilizar diferentes tipos de habitats, é encontrado em maior abundância em áreas de campo e cerrado sensu stricto, podendo utilizar as outras áreas apenas marginalmente, para alimentação ou nidificação. As espécies de hábito arborícola Rhipidomys macrurus e Gracilinanus agilis foram as mais abundantes nas matas de galerias da Rebio e do PNB.

Necromys lasiurus apresentou $20 \%$ de suas amostras positivas para Leishmania spp. Esta espécie foi considerada por alguns autores como potencial reservatório, devido o seu papel na manutenção da infecção e no potencial para transmitir o parasito para os vetores (Brandão-Filho et al., 2003; de Freitas et al., 2012). A taxa de infecção por espécie variou de 16,7 a $28 \%$, com exceção do Clyomys laticeps, onde um dos dois indivíduos capturados estava infectado. Entretanto não foram observadas diferenças significativas comparando a proporção de indivíduos infectados por Leishmania entre as espécies. O envolvimento de pelos menos 6 espécies de gêneros diferentes de mamíferos silvestres no ciclo biológico de Leishmania spp. nas unidades de conservação estudadas ilustra a complexidade dos ciclos enzoóticos desses parasitos.

Cada espécie de hospedeiro deve ter um papel distinto na transmissão de Leishmania de acordo com diferentes cenários espaciais e temporais (Roque \& Jansen, 2014). No presente estudo apresentam-se evidências de associação de Leishmania amazonensis com roedores cursoriais ( $N$. lasiurus) em fitofisionomia campestre no PNB e de $L$. braziliensis com $N$. lasiurus em cerrado sensu stricto na Rebio. Adicionalmente $L$. braziliensis está associada a roedores arborícolas $(R$. macrurus) de matas de galeria. Futuros estudos incluindo métodos que avaliem a parasitemia nesses animais (hemocultura, xenodiagnóstico, 
qPCR) poderão revelar se os mesmos seriam hospedeiros de manutenção ou de amplificação (Roque \& Jansen 2014). Adicionalmente o estudo da infecção natural dos flebotomíneos assim como a caracterização molecular das espécies de Leishmania poderão fornecer mais dados para entender como é a dinâmica de transmissão nessas áreas.

A positividade na amplificação do $24 \mathrm{Sa}$ rRNA sugestivo para Leishmania spp. $(20,1 \%, n=36)$ foi semelhante à positividade de infecção por Leishmania encontrada em outros estudos com pequenos mamíferos (Brandão-Filho et al. 2003, Oliveira et al. 2005, Quaresma et al. 2011, Lima et al. 2013). Um estudo realizado no sudeste do Brasil registrou, por meio de PCR, $24,7 \%$ de positividade para Leishmania spp. entre roedores e marsupiais (Quaresma et al. 2011). Porém, com os iniciadores ITS1, mais específicos para Leishmania spp., a positividade foi bem inferior $(4,5 \%, n=8)$. As diferenças nas taxas de positividade de infecção por Leishmania spp. entre os estudos podem ser influenciadas pelas diferenças metodológicas, como o número e as espécies de mamíferos amostrados, os protocolos e iniciadores de PCR utilizados, entre outros. Cada método de PCR pode ser afetado por diversas variáveis e deve ser selecionado de acordo com 0 objetivo específico, com a amostra disponível para a extração de DNA e com as instalações e conhecimento técnico disponível (Cruz et al. 2013). A PCR com alvo na amplificação da região polimórfica do D7 do gene 24Sa rRNA, que corresponde a sequências conservadas dos genomas de tripanossomatídeos, apresentam fragmentos com pesos moleculares diferentes para Leishmania spp., Trypanosoma rangeli e Trypanosoma cruzi (Briones et al. 1999, Souto et al. 1999, Schijman et al. 2006), mostrando ser uma ferramenta mais sensível quando comparada com outros primers, além de ser utilizada para o diagnóstico diferencial de infecção por diferentes tripanossomatídeos em reservatórios de áreas endêmicas. Já a PCR-ITS1 possui menor sensibilidade, como mostrado por Tojal da Silva et al. (2006). Neste estudo, a análise do DNA extraído de biópsias de pele de humanos infectados por Leishmania spp. indicou que a positividade da PCR-ITS1 
(82\%) foi baixa em comparação com o mkDNA (100\%). Em outro estudo com sangue humano e de cão, a PCR-ssu-rDNA foi mais sensível que a PCR-ITS1 (Schoönian et al. 2003). No entanto, quando realizado PCR-ITS1 nested, o nível de sensibilidade aumenta consideravelmente, podendo igualar com os outros primers (Schoönian et al. 2003, Cruz et al. 2013).

Também foram encontradas diferenças de positividade em relação as amostras analisadas. Ficou claro que o percentual de amostras de pele positivas nos testes moleculares foi bem maior que os obtidos com o sangue em papel de filtro. Vários estudos mostram divergência nos resultados das análises de amostras diferentes coletadas de um mesmo indivíduo. Quaresma e colaboradores (2011) encontraram uma maior positividade para Leishmania spp., utilizando testes moleculares, em amostras de pele da cauda de pequenos mamíferos, comparando com as amostras de fragmento da orelha, baço e fígado. Lima e colaboradores (2013), também utilizando testes moleculares, encontraram maior positividade para Leishmania spp. em amostras de baço de pequenos mamíferos capturados em 2003, comparando com os fragmentos de orelha, e poucos indivíduos tiveram ambas as amostras (baço e pele) positivas. Porém, em pequenos mamíferos capturados em 2006, utilizando as mesmas técnicas moleculares, Lima e colaboradores (2013) encontraram uma maior positividade nos fragmentos de orelha, com relação às amostras de baço. Outro fato que pode explicar a diferença de positividade entre as amostras no presente estudo é o método de extração de DNA, onde para as amostras de pele foi utilizado o kit de extração, o que rendeu melhor qualidade e maior quantidade de DNA, comparando com o método de fervura para extração do DNA do sangue em papel filtro. Além disso, o DNA não é homogeneamente distribuído no organismo como são os anticorpos, e sim de modo agregado, ou seja, a detecção do parasito no indivíduo vai depender da presença do DNA na amostra coletada. 
Nossos resultados também demonstram a circulação de outros protozoários do gênero Trypanosoma em roedores silvestres e marsupiais no Distrito Federal. Os produtos da PCR-ITS1 de algumas amostras que foram sequenciados, embora tivessem sido gerados com primers específicos para Leishmania, produziram fragmentos de tamanho diferente ao esperado, resultantes de anelamento parcial dos primers. Sequências de DNA obtidas a partir de amostras de quatro $N$. lasiurus e um $G$. agilis mostraram identidade variando entre 79 e $99 \%$ com T. lewisi, T. Grosi, T. otospermophili e T. kuseli. Essas quatro espécies são tripanossomas de roedores (Hoare 1972, Karbowiak e Wita 2004, Sato et al. 2007, Da Silva et al. 2010). Trypanosoma lewisi é um parasito de células sanguíneas comum em Rattus spp. de todas as partes do mundo, transmitido por pulgas, e T. Grosi possui uma restrição de hospedeiros, sendo encontrado em pequenos roedores do género Apodemus, distribuído na Europa e na Ásia (Hoare 1972, Karbowiak e Wita 2004). Trypanosoma otospermophili e T. kuseli são tripanossomas de esquilos também transmitidos por pulgas que ocorrem tanto no novo quanto no velho mundo (Hoare 1972, Sato et al. 2007). A identificação desses tripanossomas necessita de confirmação porque a maioria das amostras apresentaram valores de identidade $<90 \%$ e nós não temos nenhuma evidência morfológica para apoiar estes resultados. É possível que estes tripanossomas pertençam a outras espécies como, por exemplo, T. forattinii e T. akodoni, detectadas em roedores no Brasil dos géneros Oryzomys e Akodon, respectivamente (Hoare 1972), e que não estão depositadas no GenBank. Embora estes protozoários sejam específicos do hospedeiro e não patogénico para seres humanos, os estudos mostram que, pelo menos, $T$. lewisi pode desempenhar um papel como um parasita oportunista em seres humanos e macacos em cativeiro (De Sousa 2014).

Todas as 19 amostras dos cães estudados foram positivas ao teste DPP, porém, apenas cinco $(26,3 \%)$ foram positivas para Leishmania spp. por meio dos testes moleculares. Os resultados do teste sorológico utilizando um método baseado em antígenos recombinantes específicos para a infecção 
por L. infantum devem ser considerados com certa cautela uma vez que alguns cães submetidos à vacinação contra a doença podem induzir resposta imunológica humoral, levando a resultados sorológicos falsos positivos para $L$. infantum. Além disso, os testes sorológicos podem levar a reações cruzadas com outros tripanossomatídeos. Dois dos cães positivos haviam sido vacinados contra LV e os mesmos não apresentavam sinais da doença, enquanto outros dois dos positivos apresentavam sinais clínicos como emagrecimento, onicogrifose ou lesões cutâneas e não haviam sido vacinados. Este fato nos faz questionar sobre a eficácia da vacina contra a infecção, mas também sobre seu efeito protetor contra a manisfestação da doença. Romero \& Boelaert (2010) relatam que as vacinas de cães já registradas no Brasil têm algum efeito protetor contra LV canina, mas nenhuma delas foi devidamente avaliada como medida de controle contra LV humana. As evidências atuais indicam que as coleiras impregnadas com inseticidas para os cães possuem vantagens sobre os outros métodos de controle da LV (Romero \& Boelaert, 2010), como, por exemplo, o efeito residual mais longo comparado com a nebulização espacial no peridomićílio e o fato de não induzir resposta imunológica humoral como na vacinação. Neste estudo nenhum dos cães positivos para os testes moleculares usava coleira impregnada com inseticida.

Dos cinco cães positivos para Leishmania spp. por meio dos testes moleculares, apenas um cão, que não havia sido vacinado e apresentava sinais da doença, apresentou positividade com todos os marcadores. A PCR-ITS1 mostrou os mesmos resultados encontrados na PCR-24Sa rRNA, porém, apresentou diferença comparando com os resultados da PCR-kDNA, que mesmo sendo considerada uma técnica mais sensível, não conseguiu reproduzir os resultados encontrados com os outros marcadores. Apesar de serem técnicas que utilizam marcadores diferentes, este fato não pode ser totalmente explicado, sendo uma limitação do trabalho, uma vez que a PCRkDNA não foi realizada em triplicata, o que seria necessário para a confirmação dos resultados. 
Os resultados deste trabalho sugerem o envolvimento de algumas espécies de mamíferos no ciclo de Leishmania e Trypanosoma nas unidades de conservação do DF, ampliando o conhecimento dos ciclos enzoóticos de tripanossomatídeos no cerrado. Porém, outros estudos monitorando a infecção a partir de técnicas parasitológicas (ex. hemocultura) e moleculares mais sensíveis (ex. qPCR, nested-PCR) (Cruz et al 2013), ao longo de um maior período de tempo são necessários para determinar se esses mamíferos atuam como reservatórios desses parasitos.

Apesar dos resultados obtidos indicarem a presença de $L$. infantum no ciclo doméstico, tendo o cão como reservatório, este estudo sofreu uma limitação devido ao pequeno número de cães estudados, sendo necessária uma amostragem maior, para que possamos entender melhor os ciclos da Leishmania spp. Além disso, o presente estudo focou em mamíferos silvestres em unidades de conservação, havendo necessidade de ampliar os estudos com mamíferos sinantrópicos (e.g. Didelphis albiventris) no peridomicílio. Outra limitação foi a não realização dos testes sorológicos nos animais silvestres e a pequena quantidade de DNA extraído das amostras coletadas, sendo importante em futuros estudos a coleta de amostras que possibilitem um maior rendimento de material genético. 


\section{CONCLUSÕES}

$\mathrm{Na}$ área estudada não está ocorrendo transbordamento de Leishmania spp. do ambiente silvestre para o domiciliar e o ciclo da Leishmania infantum está se mantendo apenas entre os cães das residências.

Pelos menos 6 espécies de gêneros diferentes de mamíferos silvestres podem participar do ciclo enzoótico de Leishmania spp. no DF, destacando $N$. lasiurus como hospedeiro de $L$. amazonensis e $L$. braziliensis e R. macrurus como hospedeiro de L. braziliensis.

Fragmentos de DNA de outros tripanossomatídeos, que provavelmente são espécies de Trypanosoma de roedores ainda não depositadas no GenBank, também foram encontrados em N. lasiurus e G. agilis.

Não foram observadas diferenças significativas comparando a proporção de indivíduos infectados por Leishmania spp. entre as duas áreas amostradas e entre as espécies de mamíferos silvestres.

A PCR-24Sa rRNA foi mais sensível no diagnóstico de Leishmania spp. comparada com a PCR-ITS1, porém, menos específica. Apesar da PCR-ITS1 ter apresentado produtos com pares de bases acima do esperado para Leishmania spp., a PCR-24Sa rRNA apresentou mais bandas com diferentes pesos moleculares referentes a outros tripanossomatídeos. 


\section{REFERÊNCIAS BIBLIOGRÁFICAS}

Aagaard-Hansen J, Nombela N, Alvar J. Population movement: a key factor in the epidemiology of neglected tropical diseases. Tropical Medicine \& International Health. 2010;15(11):1281-8.

Aguiar GM, Medeiros WM. Distribuição e Hábitats. In: Rangel, E.F. \& Lainson, R. Flebotomíneos do Brasil. Rio de Janeiro. Editora Fiocruz. 2003. p. 207-255.

Aguilar CM, Rangel EF, Garcia L, Fernandez E, Momen H, Grimaldi G, Vargas Z. Zoonotic cutaneous leishmaniasis due to Leishmania (Viannia) braziliensis associated with domestic animals in Venezuela and Brazil. Memórias do Instituto Oswaldo Cruz. 1989; 84(1):19-28.

Alho CJ, Pereira LA, Paula AC. Patterns of habitat utilization by small mammals population in cerrado biome of Central Brazil. Mammalia. 1986; 50(4):447-460.

Alvar J, Velez ID, Bern C, Herrero M, Desjeux P, Cano J, et al. Leishmaniasis worldwide and global estimates of its incidence. PloS one. 2012;7(5):e35671.

Andrade AJ, Shimabukuro PHF, Galati EAB. On the taxonomic status of Phlebotomus breviductus Barretto, 1950 (Diptera: Psychodidae: Phlebotominae). Zootaxa. 2013; 3734: 477-484.

Aransay AM, Scoulica E, Tselentis Y. Detection and identification of Leishmania DNA within naturally infected sand flies by seminested PCR on minicircle kinetoplastic DNA. Applied and Environmental Microbiology. 2000; 66(5):1933-8.

Asfora PH, Palma ART, Astúa D, Geise L. Distribution of Oecomys catherinae Thomas, 1909 (Rodentia: Cricetidae) in northeastern Brazil with karyotypical and morphometrical notes. Biota Neotropica. 2011; 11(2):415- 
424.

Ashford RW. When is a reservoir not a reservoir? Emerging Infectious Diseases. 2003; 9:1495-1496.

Barbosa Md, Fé NF, Marcião AH, Silva AP, Monteiro WM, Guerra JA. Sandfly fauna (Diptera: Psychodidae) in a focus of American cutaneous leishmaniasis on the urban periphery of Manaus, State of Amazonas. Revista da Sociedade Brasileira de Medicina Tropical. 2008; 41(5):485-91.

Barretto, M. P. Epidemiologia. In: Brener, Z. \& Andrade, Z. A. (eds.) Trypanosoma cruzi e Doença de Chagas. Rio de Janeiro: Guanabara Koogan. 1979; Pág. 89-151.

Bonvicino CR, Oliveira JA, D'Andrea PS. Guia dos Roedores do Brasil, com chaves para gêneros baseadas em caracteres externos. Rio de Janeiro: Centro Pan-Americano de Febre Aftosa - OPAS/OMS. 2008. 120 p.: il. (Série de Manuais Técnicos, 11).

Brandao SP, Brito ME, Carvalho FG, Ishikawa EA, Cupolillo E, Floeter-Winter $\mathrm{L}$, et al. Wild and synanthropic hosts of Leishmania (Viannia) braziliensis in the endemic cutaneous leishmaniasis locality of Amaraji, Pernambuco State, Brazil. Transactions of the Royal Society of Tropical Medicine and Hygiene. 2003;97(3):291-6.

Brandão-Filho SP, Campbell-Lendrum D, Brito ME, Shaw JJ and Davies C R. Epidemiological surveys confirm an increasing burden of cutaneous leishmaniasis in north-east Brazi. Transactions of the Royal Society of Tropical Medicine and Hygiene. 1999; 93(5):488-94.

Brandao-filho SP, Decarvalho FG, Debrito MEF, Almeida FD, Nascimento LA. American cutaneous leishmaniasis in Pernambuco, Brazil - ecoepidemiologic aspects in zona da mata region. Memórias do Instituto Oswaldo Cruz. 1994;89(3):445-9. 
Brasil. Ministério da Saúde. Secretaria de Vigilância em Saúde. Manual de Vigilância e Controle da Leishmaniose Visceral. 1a․ Edição. Brasília - DF: editora do Ministério da Saúde, 2006. 120 p.- (Série A. Normas e Manuais Técnicos).

Brasil. Ministério da Saúde. Secretaria de Vigilância em Saúde. Manual de Vigilância da Leishmaniose Tegumentar Americana / Ministério da Saúde, Secretaria de Vigilância em Saúde. - 2. ed. atual. - Brasília: Editora do Ministério da Saúde, 2010. 180 p.- (Série A. Normas e Manuais Técnicos).

Brazil RP, Nascimento MDSB, Macau RP. Infecção natural do porco (Sus scrofa) por Leishmania em foco recente de Leishmaniose Tegumentar na Ilha de São Luís, Maranhão. Memórias do Instituto Oswaldo Cruz. 1987; 82: 145.

Briones MR, Souto RP, Stolf BS, Zingales B. The evolution of two Trypanosoma cruzi subgroups inferred from rRNA genes can be correlated with the interchange of American mammalian faunas in the Cenozoic and has implications to pathogenicity and host specificity. Molecular and Biochemical Parasitology. 1999; 104: 219-232.

Cabrera MAA, Paula AA, Camacho LAB, Marzochi MCA, Xavier SC, Da Silva AVM, et al. Canine visceral leishmaniasis in Barra de Guaratiba, Rio de Janeiro, Brazil: assessment of risk factors. Revista do Instituto de Medicina Tropical de São Paulo. 2003;45(2):79-83.

Carranza-Tamayo CO, de Carvalho MDL, Bredt A, Bofil MIR, Rodrigues $R M B$, da Silva $A D$, et al. Autochthonous visceral leishmaniasis in Brasilia, Federal District, Brazil. Revista da Sociedade Brasileira de Medicina Tropical. 2010;43(4):396-9.

Carranza-Tamayo CO. Caracterização e acompanhamento geo-referenciado do primeiro foco de transmissão de leishmaniose visceral humana em Brasília, Distrito Federal. Brasília. [Tese] - Universidade de Brasília; 2010. 
Carreira JCA, da Silva AVM, Pereira DD, Brazil RP. Natural infection of Didelphis aurita (Mammalia: Marsupialia) with Leishmania infantum in Brazil. Parasites Vectors. 2012;5:111.

Carvalho MSL, Bredt A, Meneghin ERS, Oliveira C. Flebotomíneos (Diptera: Psychodidae) em áreas de ocorrência de leishmaniose tegumentar americana no Distrito Federal, Brasil, 2006 a 2008. Epidemiologia e Serviços de Saúde. 2010; 19: 227-237.

Castro EA, Thomaz-Soccol V, Augur C, Luz E. Leishmania (Viannia) braziliensis: epidemiology of canine cutaneous leishmaniasis in the state of Paraná (Brazil). Experimental parasitology. 2007;117:13-21.

Corredor A, Gallego JF, Tesh RB, Peláez D, Diaz A, Montilla M, Paláu MT. Didelphis marsupialis, an apparent wild reservoir of Leishmania donovani chagasi in Colômbia, South America. Transactions of the Royal Society of Tropical Medicine and Hygiene. 1989; 83:195.

Cortes S, Rolão N, Ramada J, Campino L. PCR as a rapid and sensitive tool in the diagnosis of human and canine leishmaniasis using Leishmania donovani s. I.- specific kinetoplastid primers. Transactions of the Royal Society of Tropical Medicine and Hygiene. 2004; 98: 12-17.

Cruz I, Millet A, Carrillo E, Chenik M, Salotra P, Verma S, et al. An approach for interlaboratory comparison of conventional and real-time PCR assays for diagnosis of human leishmaniasis. Experimental parasitology. 2013;134(3):281-9.

Curi NHA, Miranda I, Talamoni SA. Serologic evidence of Leishmania infection in free-ranging wild and domestic canids around a Brazilian national park. Memórias do Instituto Oswaldo Cruz. 2006; 101:99-101.

Da Silva FM, Marcili A, Ortiz PA, Epiphanio S, Campaner M, Catão-Dias JL, Shaw JJ, Camargo EP, Teixeira MMG. Phylogenetic, morphological and behavioural analyses support host switching of Trypanosoma (Herpetosoma) 
lewisi from domestic rats to primates. Infection, Genetics and Evolution. 2010; 10: 522-529.

Dahroug MAA, Almeida ABPF, Sousa VRF, Dutra V, Turbino NCMR, Nakazato L, et al. Leishmania (Leishmania) chagasi in captive wild felids in Brazil. Transactions of the Royal Society of Tropical Medicine and Hygiene. 2010;104(1):73-4.

Dantas-Torres F, Brandão-Filho SP. Visceral leishmaniasis in Brazil: revisiting the paradigms of epidemiology and control. Revista do Instituto de Medicina Tropical de São Paulo. 2006; 48 (3): 151-156.

Dantas-Torres F. Canine leishmaniasis in South America. Parasites and Vectors. 2009. 2 (Suppl. 1):S1

Dantas-Torres F. The role of dogs as reservoirs of Leishmania parasites, with emphasis on Leishmania (Leishmania) infantum and Leishmania (Viannia) braziliensis. Veterinary parasitology. 2007;149(3-4):139-46.

De Araújo VA, Boite MC, Cupolillo E, Jansen AM, Roque AL. Mixed infection in the anteater Tamandua tetradactyla (Mammalia: Pilosa) from Para State, Brazil: Trypanosoma cruzi, T. rangeli and Leishmania infantum. Parasitology. 2013;140(4):455-60.

De Freitas TP, D'Andrea PS, de Paula DA, Nakazato L, Dutra V, Bonvicino $\mathrm{CR}$, et al. Natural infection of Leishmania (Viannia) braziliensis in Mus musculus captured in Mato Grosso, Brazil. Vector Borne and Zoonotic Diseases. 2012; 12:81-83.

De Lima H, De Guglielmo Z, Rodríguez A, Convit J, Rodriguez N. Cotton rats (Sigmodon hispidus) and black rats (Rattus rattus) as possible reservoirs of Leishmania spp. in Lara state, Venezuela. Memórias do Instituto Oswaldo Cruz. 2002; 97(2): 169-174.

De Sousa MA: On opportunist infections by Trypanosoma lewisi in humans 
and its differential diagnosis from $T$. cruzi and $T$. rangeli. Parasitology research. 2014; 113:4471-4475.

De Souza Al, Barros EM, Ishikawa E, Ilha IM, Marin GR, Nunes VL. Feline leishmaniasis due to Leishmania (Leishmania) amazonensis in Mato Grosso do Sul State, Brazil. Veterinary parasitology. 2005;128(1-2):41-5.

Dedet JP, Pajot FX, Desjeux P, Goyot P, Chippaux JP, Geoffroy B. Natural hosts of Leishmania-mexicana-amazonensis lainson and shaw, 1972 (kinetoplastida, Trypanosomatidae) in French-Guyana. Transactions of the Royal Society of Tropical Medicine and Hygiene. 1985;79(3):302-5.

Diniz MM, Ovallos FG1, de Castro Gomes CM, de Oliveira Lavitschka C, Galati EA. Host-biting rate and susceptibility of some suspected vectors to Leishmania braziliensis. Parasites Vectors. 2014. 31(7):139.

Dos Santos SO, Arias J, Ribeiro AA, Hoffmann MD, De Freitas RA, Malacco MAF. Incrimination of Lutzomyia cruzi as a vector of American Visceral Leishmaniasis. Medical and Veterinary Entomology. 1998;12(3):315-7.

du Breuil RM, Patel JM, Mendelow BV. Quantitation of beta-actin-specific mRNA transcripts using xeno-competitive PCR. PCR Methods and Applications. 1993; 3:57-59.

Ferreira EC, de Lana M, Carneiro M, Reis AB, Paes DV, Silva ES, Schallig $\mathrm{H}$, Gontijo CM. Comparison of serological assays for the diagnosis of canine visceral leishmaniasis in animals presenting different clinical manifestations. Veterinary parasitology. 2007; 146 (3-4): 235-241.

Ferreira JBC, Macedo MA, Rocha DA, Ferreira TS, Obara MT, GurgelGonçalves R. Ocorrência de flebotomíneos (Diptera: Psychodidae) em matas de galeria no Distrito Federal, Brasil. Entomobrasilis (Vassouras). 2014. No prelo.

Figueiredo FB, Gremião ID, Pereira SA, Fedulo LP, Menezes RC, Balthazar 
DA, et al. First report of natural infection of a bush dog (Speothos venaticus) with Leishmania (Leishmania) chagasi in Brazil. Transactions of the Royal Society of Tropical Medicine and Hygiene. 2008; 102:200-201

Forattini OP, Pattoli DBG, Rabello EX, Ferreira OA. Natural infection of sylvatic mammals of cutaneous leishmaniasis in S. Paulo State, Brazil. Revista de Saúde Pública 1972;6(3):255-61.

Forattini OP, Pattoli DBG, Rabello EX, Ferreira OA. Natural infection of Oryzomys capito laticeps in enzootic focus of cutaneous leishmaniasis in São Paulo State, Brazil. Revista de Saúde Pública. 1973;7(2):181-4.

Gentile B, Lepont F, Pajot FX, Besnard R. Dermal leishmaniasis in French Guiana - the sloth (Choloepus-didactylus) as a reservoir host. Transactions of the Royal Society of Tropical Medicine and Hygiene. 1981;75(4):612-3.

Haydon DT, Cleaveland S, Taylor LH, Laurenson MK. Identifying reservoirs of infection: a conceptual and practical challenge. Emerging Infectious Diseases. 2002;8: 1468-1473.

Herrera HM, Abreu UG, Keuroghlian A, Freitas TP, Jansen AM. The role played by sympatric collared peccary (Tayassu tajacu), white-lipped peccary (Tayassu pecari), and feral pig (Sus scrofa) as maintenance hosts for Trypanosoma evansi and Trypanosoma cruzi in a sylvatic area of Brazil. Parasitology research. 2008a;103(3):619-24.

Herrera HM, Lisboa CV, Pinho AP, Olifiers N, Bianchi RC, Rocha FL, et al. The coati (Nasua nasua, Carnivora, Procyonidae) as a reservoir host for the main lineages of Trypanosoma cruzi in the Pantanal region, Brazil. Transactions of the Royal Society of Tropical Medicine and Hygiene. 2008b; 102(11):1133-9.

Hoare CA. The trypanosomes of mammals. A zoological monograph. Oxford: Blackwell Scientific Publications. 1972. 
Humberg RM, Oshiro ET, Cruz Mdo S, Ribolla PE, Alonso DP, Ferreira AM, et al. Leishmania chagasi in opossums (Didelphis albiventris) in an urban area endemic for visceral leishmaniasis, Campo Grande, Mato Grosso do Sul, Brazil. The American Journal of Tropical Medicine and Hygiene. 2012; 87(3):470-2.

Karagiannis-Voules DA, Scholte RG, Guimaraes LH, Utzinger J, Vounatsou P. Bayesian geostatistical modeling of leishmaniasis incidence in Brazil. PLoS neglected tropical diseases. 2013; 7(5):e2213.

Karbowiak G e Wita I. Trypanosoma (Herpetosoma) grosi kosewiense subsp. n., the Parasite of the Yellow-Necked Mouse Apodemus flavicollis (Melchior, 1834). Acta Protozoologica. 2004: 43:173-178.

Killick-Kendrick R. Phlebotomine vectors of leishmaniasis: a review. Medical and veterinary entomology. 1990; 4:1-24.

Killick-Kendrick R; Ward DH. Transmition of leishmaniosis by the bait of phlebotomine sandfly: possible mechanism. Transactions of the Royal Society of Tropical Medicine and Hygiene. 1981; 75(1):152-154.

Krebs CJ. Ecological Methodology, 2nd ed., Addison-Welsey Educational Publishers, Inc., Menlo Park, CA. 1999; 620 p.

Lachaud L, Chabbert E, Dubessay P, Reynes J, Lamothe J, Bastien P. Leishmaniasis Using Peripheral Blood Methods for PCR Diagnosis of Visceral Comparison of Various Sample Preparation. Journal of Clinical Microbiology. 2001; 39(2):613-17.

Lainson R, Dye C, Shaw JJ, Macdonald D, Courtenay O, Souza AA, Silveira FT. Amazonian visceral leishmaniasis: distribution of the vector Lutzomyia longipalpis (Lutz \& Neiva) in relation to the fox Cerdocyon thous (L.) and the efficiency of this reservoir host as a source of infection. Memórias do Instituto Oswaldo Cruz. 1990; 85: 135-137. 
Lainson R, Rangel EF. Lutzomyia longipalpis and the eco-epidemiology of American visceral leishmaniasis, with particular reference to Brazil: a review. Memórias do Instituto Oswaldo Cruz. 2005; 100(8): 811- 27.

Lainson R, Shaw JJ, Lins ZC. Leishmaniasis in Brazil. 4. Fox, Cerdocyon thous (I) as a reservoir of Leishmania-donovani in para-state, Brazil. Transactions of the Royal Society of Tropical Medicine and Hygiene. 1969; 63(6):741

Lainson R, Shaw JJ, Ready PD, Miles MA, Povoa M. Leishmaniasis in Brazil.16. Isolation and identification of Leishmania species from sandflies, wild mammals and man in north para state, with particular reference to $L$. braziliensis-guyanensis causative agent of pian-bois. Transactions of the Royal Society of Tropical Medicine and Hygiene. 1981; 75(4):530-8.

Lainson R, Shaw JJ, Ward RD, Ready PD, Naiff RD. Leishmaniasis in Brazil.13. Isolation of Leishmania from armadillos (Dasypus-novemcinctus), and observations on the epidemiology of cutaneous leishmaniasis in north para state. Transactions of the Royal Society of Tropical Medicine and Hygiene. 1979; 73(2):239-42.

Lainson R, Shaw JJ. Leishmaniasis in Brazil: I. Observations on enzootic rodent leishmaniasis - incrimination of Lutzomyia flaviscutellata Mangabeira) as the vector in the lower Amazonian basin. Transactions of the Royal Society of Tropical Medicine and Hygiene. 1968; 62 (3): 385-395.

Lainson R, Shaw JJ. Leishmaniasis in Brazil: V. Studies on the epidemiology of cutaneous leishmaniasis in Mato Grosso state, and observations on two distinct strains of Leishmania isolated form man and forest animals. Transactions of the Royal Society of Tropical Medicine and Hygiene. 1970; 64 (5): 654-667.

Lainson R, Shaw JJ. Leishmaniasis of the New World: taxonomia problems. British Medical Bulletin. 1972; 28: 44-48. 
Lainson R. The Neotropical Leishmania species: a brief historical review of their discovery, ecology and taxonomy. Revista Pan-Amazônica de Saúde. 2010;1(2):13-32.

Lima BS, Dantas-Torres F, de Carvalho MR, Marinho-Junior JF, de Almeida EL, Brito MEF, Gomes F, Brandão-Filho SP. Small mammals as hosts of Leishmania spp. in a highly endemic area for zoonotic leishmaniasis in north-eastern Brazil. Transactions of the Royal Society of Tropical Medicine and Hygiene. 2013; 107: 592-597.

Madeira MF, Schubach AO, Schubach TMP, Pacheco RS, Oliveira FS, Pereira SA, Figueiredo FB, Baptista C, Marzochi MCA. Mixed infection with Leishmania (Viannia) braziliensis and Leishmania (Leishmania) chagasi in a naturally infected dog from Rio de Janeiro, Brazil. Transactions of the Royal Society of Tropical Medicine and Hygiene. 2006; 100 (5): 442-445.

Madeira MF, Sousa MA, Barros JHS, Figueiredo FB, Fagundes A, Schubach A, de Paula CC, Faissal BNS, Fonseca TS, Thoma HK, Marzochi MCA. Trypanosoma caninum n. sp. (Protozoa: Kinetoplastida) isolated from intact skin of a domestic dog (Canis familiaris) captured in Rio de Janeiro, Brazil. Parasitology. 2009; 136(4):411-23.

Madeira MF, Uchoa CMA, Leal CA, Silva RMM, Duarte R, Magalhães CM Serra CMB. Leishmania (viannia) braziliensis em cães naturalmente infectados. Revista da Sociedade Brasileira de Medicina Tropical. 2003; 36: 551-555.

Marinho-Filho J, Reis ML, Oliveira PS, Vieira EM, Paes MN. Diversity standards and small mammal numbers: conservation of the cerrado biodiversity forests in the zoogeography of the cerrado's nonvolant mammalian fauna. Anais da Academia Brasileira de Ciências. 1994; 66(supl.1):149-157. 
Marques MJ, Volpini AC, Genaro O, Mayrink W, Romanha AJ. Simple form of clinical sample preservation and Leishmania DNA extraction from human lesions for diagnosis of American cutaneous leishmaniasis via polymerase chain reaction. The American Journal of Tropical Medicine and Hygiene. 2001; 65:902-906.

Oliveira FS, Pirmez C, Pires MQ et al. PCR-based diagnosis for detection of Leishmania in skin and blood of rodents from an endemic area of cutaneous and visceral leishmaniasis in Brazil. Veterinary parasitology. 2005; 129:21927.

Oliveira GM, Madeira MF, Oliveira FS, Pacheco RD. PCR associated to molecular hybridization detects Leishmania (Viannia) braziliensis in healthy skin in canine tegumentary leishmaniasis. Journal of Parasitology. 2014 Aug 26. [Epub ahead of print] PubMed PMID: 25158080.

OPAS/OMS. Organização Pan-Americana da Saúde/Organização Mundial da Saúde (OPAS/OMS). Saúde nas Américas: panorama regional e perfis de países. 2012. Publicação científica e técnica $n^{\circ}$ 636. Edição de 2012. 223p.

PAHO. Pan American Health Organization. Cutaneous and Mucosal Leishmaniasis [Internet]; 2014. Disponível em http://www.paho.org/hq/index.php?option=com_content\&view=article\&id=641 7\&ltemid=39345\&lang=en. Acessado em: 22 de junho de 2014.

Paiva-Cavalcanti M, Felinto de Brito ME, de Souza WV, de Miranda Gomes $\mathrm{Y}$, Abath FG. The development of a real-time PCR assay for the quantification of Leishmania infantum DNA in canine blood. The Veterinary Journal. 2009;189:356-8.

Peterson N E, Vexemat JA, Rosa ACOC, Lago PRL. Isolation of Leishmania (Viannia) braziliensis from the rodent Nectomys squamipes captured in Bahia, Brazil. Memórias do Instituto Oswaldo Cruz. 1988. 83 (S1), 28.

Pita-Pereira D, Souza GD, Zwetsch A, Alves CR, Britto C, Rangel EF. First 
report of Lutzomyia (Nyssomyia) neivai (Diptera: Psychodidae: Phlebotominae) naturally infected by Leishmania (Viannia) braziliensis in a periurban area of south Brazil using a multiplex polymerase chain reaction assay. The American Journal of Tropical Medicine and Hygiene. 2009; 80(4):593-5.

Pita-Pereira Dd, Souza GD, Pereira Tde A, Zwetsch A, Britto C, Rangel EF. Lutzomyia (Pintomyia) fischeri (Diptera: Psychodidae: Phlebotominae), a probable vector of American cutaneous leishmaniasis: detection of natural infection by Leishmania (Viannia) DNA in specimens from the municipality of Porto Alegre (RS), Brazil, using multiplex PCR assay. Acta tropica. 2011; 120(3):273-5.

Quaresma PF, Rego FD, Botelho HA, da Silva SR, Moura Junior AJ, Teixeira Neto RG, et al. Wild, synanthropic and domestic hosts of Leishmania in an endemic area of cutaneous leishmaniasis in Minas Gerais State, Brazil. Transactions of the Royal Society of Tropical Medicine and Hygiene. 2011; 105(10):579-85 .

Rangel EF, Lainson R. Proven and putative vectors of American cutaneous leishmaniasis in Brazil: aspects of their biology and vectorial competence. Memórias do Instituto Oswaldo Cruz. 2009: 104(7): 937-54.

Ready PD. Biology of phlebotomine sand flies as vectors of disease agents. Annual Review of Entomology. 2013;58:227-50.

Reis NR, Peracchi AL, Pedro WA, Lima IP. Mamíferos do Brasil. 1ํㅡㄹ ed. Londrina: Edição dos Editores. 2006. 437pp.

Ribeiro JF e Walter BMT. Fitofisionomias do bioma cerrado. In: Sano, S.M., Almeida, S.P de. (Ed.) Cerrado: ambiente e flora. Planaltina: EMBRAPACPAC, 1998. p. 89-166. Romero GA, Boelaert M. Control of visceral leishmaniasis in Latin America - A systematic review. PLoS Neglected Tropical Disease. 2010; 4(1):e584. 
Rocha FL, Roque AL, Arrais RC, Santos JP, Lima Vdos S, Xavier SC, et al. Trypanosoma cruzi Tcl and Tcll transmission among wild carnivores, small mammals and dogs in a conservation unit and surrounding areas, Brazil. Parasitology. 2013a; 140(2):160-70.

Rocha FL, Roque AL, de Lima JS, Cheida CC, Lemos FG, de Azevedo FC, et al. Trypanosoma cruzi infection in neotropical wild carnivores (Mammalia: Carnivora): at the top of the T. cruzi transmission chain. PloS one. 2013b;8(7):e67463.

Rolão N, Martins MJ, João A, Campino L. Equine infection with Leishmania in Portugal. Parasite. 2005; 12: 183-186.

Romero GA, Boelaert M. Control of visceral leishmaniasis in Latin America A systematic review. PLoS Neglected Tropical Disease. 2010; 4(1):e584.

Romero GA, Noronha EF, Pirmez C, Pires Fdo E, Fernandes O, Nehme NS, et al. Sensitivity and reproducibility of a PCR assay for Leishmania detection using skin biopsy imprints on filter paper. Acta tropica. 2009;109(1):74-7.

Roque AL, Xavier SC, Gerhardt M, Silva MF, Lima VS, D'Andrea PS, et al. Trypanosoma cruzi among wild and domestic mammals in different areas of the Abaetetuba municipality (Para State, Brazil), an endemic Chagas disease transmission area. Veterinary parasitology. 2013;193(1-3):71-7.

Roque ALR, Jansen AM. Wild and synanthropic reservoirs of Leishmania species in the Americas. International Journal for Parasitology: Parasites and Wildlife. 2014; 3:251-262

Rougeron V, Catzeflis F, Hide M, De Meeûs T, Bañuls AL. First clinical case of cutaneous leishmaniasis due to Leishmania (Viannia) braziliensis in a domestic cat from French Guiana. Veterinary parasitology. 2011; 181(24):325-8.

Sampaio RNR, Gonçalves MC, Leite VA, França BV, Santos G, Carvalho 
MSL, Tauil PL. Study on the transmission of American cutaneous leishmaniasis in the Federal District. Revista da Sociedade Brasileira de Medicina Tropical. 2009; 42: 686-690.

Santiago ME, Vasconcelos RO, Fattori KR, Munari DP, Michelin AF, Lima VM. An investigation of Leishmania spp. in Didelphis spp. from urban and peri-urban areas in Bauru (Sao Paulo, Brazil). Veterinary parasitology. 2007. 150:283-290.

Saraiva L, Andrade Filho JD, Silva SO, Andrade ASR, Melo MN. The molecular detection of different Leishmania species within sand flies from a cutaneous and visceral leishmaniasis sympatric area in Southeastern Brazil. Memórias do Instituto Oswaldo Cruz. 2010; 105: 1033-1039.

Sato H, Al-Adhami BH, Une Y, Kamiya H. Trypanosoma (Herpetosoma) kuseli sp. n. (Protozoa: Kinetoplastida) in Siberian flying squirrels (Pteromys volans). Parasitology Research. 2007;101:453-461.

Schijman AG, Lauricella MA, Marcet PL, Duffy T, Cardinal MV, Bisio M, et al. 2006. Differential detection of Blastocrithidia triatomae and Trypanosoma cruzi by amplification of 24salpha ribosomal RNA genes in faeces of sylvatic triatomine species from rural northwestern Argentina. Acta tropica. 2006;99(1):50-4.

Schoönian G, Nasereddin A, Dinse N, Schweynoch C, Schallig HDFH, resber W, Jaffe C. PCR diagnosis and characterization of Leishmania in local and imported clinical samples. Diagnostic Microbiology and Infectious Disease. 2003; 47:349-358.

Schubach EYP. Validação da técnica de imunocromatografia rápida de duplo percurso para o diagnóstico da leishmaniose visceral canina em amostras de sangue total e soro. Brasília. [Dissertação]. Brasília - Universidade de Brasília; 2011.

Schubach TMP, Figueiredo FB, Pereira SA, Madeira MF, Santos IB, Andrade 
$\mathrm{MV}$, et al. American cutaneous leishmaniasis in two cats from Rio de Janeiro, Brazil: first report of natural infection with Leishmania (Viannia) braziliensis. Transactions of the Royal Society of Tropical Medicine and Hygiene. 2004; 98(3):165-7.

SES/DF - Secretaria de Estado de Saúde do Distrito Federal. Diretoria de Vigilância Epidemiológica. Informativo Epidemiológico das Leishmanioses no DF (Leishmaniose Visceral e Tegumentar Americana), Ano 4, № 2 - Maio de 2012.

SES/DF - Secretaria de Estado de Saúde do Distrito Federal. Diretoria de Vigilância Epidemiológica. Informativo Epidemiológico das Leishmanioses no DF (Leishmaniose Visceral e Tegumentar Americana); Ano 6; № 1; Janeiro/2014.

Sherlock IA, Miranda JC, Sadigursky M, Grimaldi JrG. Natural infection of the opossum Didelphis albiventris (Marsupialia, Didelphidae) with Leishmania donovani, in Brazil. Memórias do Instituto Oswaldo Cruz. 1984; 79(4):511.

Sherlock IA. Ecological interactions of visceral leishmaniasis in the State of Bahia, Brazil. Memórias do Instituto Oswaldo Cruz. 1996; 91(6):671-83.

Shimabukuro PHF, Galati EAB. Checklist of Phlebotominae (Diptera, Psychodidae) from São Paulo State, Brazil, with notes on their geographical distribution. Biota Neotropica. 2010; 11:1-20.

Silva ES, Gontijo CMF, Pacheco RS, Fiuza VOP, Brazil RP. Visceral Leishmaniasis in the Metropolitan Region of Belo Horizonte, Satate of Minas Gerais, Brazil. Memórias do Instituto Oswaldo Cruz. 2001; 96: 285-291.

Silveira FT, Lainson R, Shaw JJ, Braga RR, Ishikawa EEA, Souza AAA. Leishmaniose cutânea na Amazônia: isolamento de Leishmania (Viannia) lainsoni do roedor Agouti paca (Rodentia: Dasyproctidae), no estado do Pará, Brasil. Revista do Instituto de Medicina Tropical de São Paulo. 1991; 33(1):18-22. 
Souto RP, Vargas N, Zingales B. Trypanosoma rangeli: discrimination from Trypanosoma cruzi based on a variable domain from the large subunit ribosomal RNA gene. Experimental parasitology. 1999; 91:306-314.

Souza Al, Nunes VLB, Borralho VM, Ishikawa EAY. Domestic feline cutaneous leishmaniasis in the municipality of Ribas do Rio Pardo, Mato Grosso do Sul state, Brazil: a case report. Journal of Venomous Animals and Toxins including Tropical Diseases. 2009; 15(2):359-65.

Souza NA, Andrade-Coêlho CA, Vilela ML, Rangel EF. The phlebotominae sand fly (Diptera: Psychodidae) fauna of two reserves in the state of Rio de Janeiro, Brazil. Memórias do Instituto Oswaldo Cruz. 2001; 96(3): 319-324.

Souza NP, de Almeida A, de Freitas TPT, da Paz RCR, Dutra V, Nakazato L, et al. Leishmania (Leishmania) infantum chagasi in wild canids kept in captivity in the State of Mato Grosso. Revista da Sociedade Brasileira de Medicina Tropical. 2010; 43(3):333-5.

Srivastava P, Dayama A, Mehrotra S, Sundar S. Diagnosis of visceral leishmaniasis. Transactions of the Royal Society of Tropical Medicine and Hygiene. 2011; 105(1):1-6.

Telleria J, Bosseno MF, Tarifa T, Buitrago R, Martinez E, Torrez M, Le Pont $F$, Brenière SF. Putative reservoirs of Leishmania amazonensis in a subandean focus of Bolívia identified by kDNA-polymerase chain reaction. Memórias do Instituto Oswaldo Cruz. 1999; 94(1): 5-6.

Tojal da Silva AC, Cupolillo E, Volpini AC, Almeida R, Romero GA. Species diversity causing human cutaneous leishmaniasis in Rio Branco, state of Acre, Brazil. Tropical Medicine \& International Health. 2006; 11:1388-1398.

Tolezano JE, Uliana SR, Taniguchi HH, Araújo MF, Barbosa JA, Barbosa JE, Floeter-Winter LM, Shaw JJ. The first records of Leishmania (Leishmania) amazonensis in dogs (Canis familiaris) diagnosed clinically as having canine 
visceral leishmaniasis from Araçatuba County, São Paulo State, Brazil. Veterinary parasitology. 2007 Nov 10;149(3-4):280-4.

Travi BL, Jaramillo C, Montoya J, Segura I, Zea A, Gonçalves A, Vélez ID. Didelphis marsupialis, an important reservoir of Trypanosoma cruzi and Leishmania (Leishmania) chagasi in Colômbia. The American Journal of Tropical Medicine and Hygiene. 1994; 84: 676-677.

WHO - World Health Organization. Media Centre: leishmaniasis [Internet]; 2014a. Disponível em: http://www.who.int/mediacentre/factsheets/fs375/en/. Acessado em: 22 de junho de 2014.

WHO - World Health Organization. Programmes: leishmaniasis [Internet]; 2014b. Disponível em: http://www.who.int/leishmaniasis/en/. Acessado em: 22 de junho de 2014.

Wilson SM. DNA-based methods in the detection of Leishmania parasites: field applications and practicalities. Annals of Tropical Medicine and Parasitology. 1995; 89(Suppl. 1):95-100. 


\section{ANEXO 1}

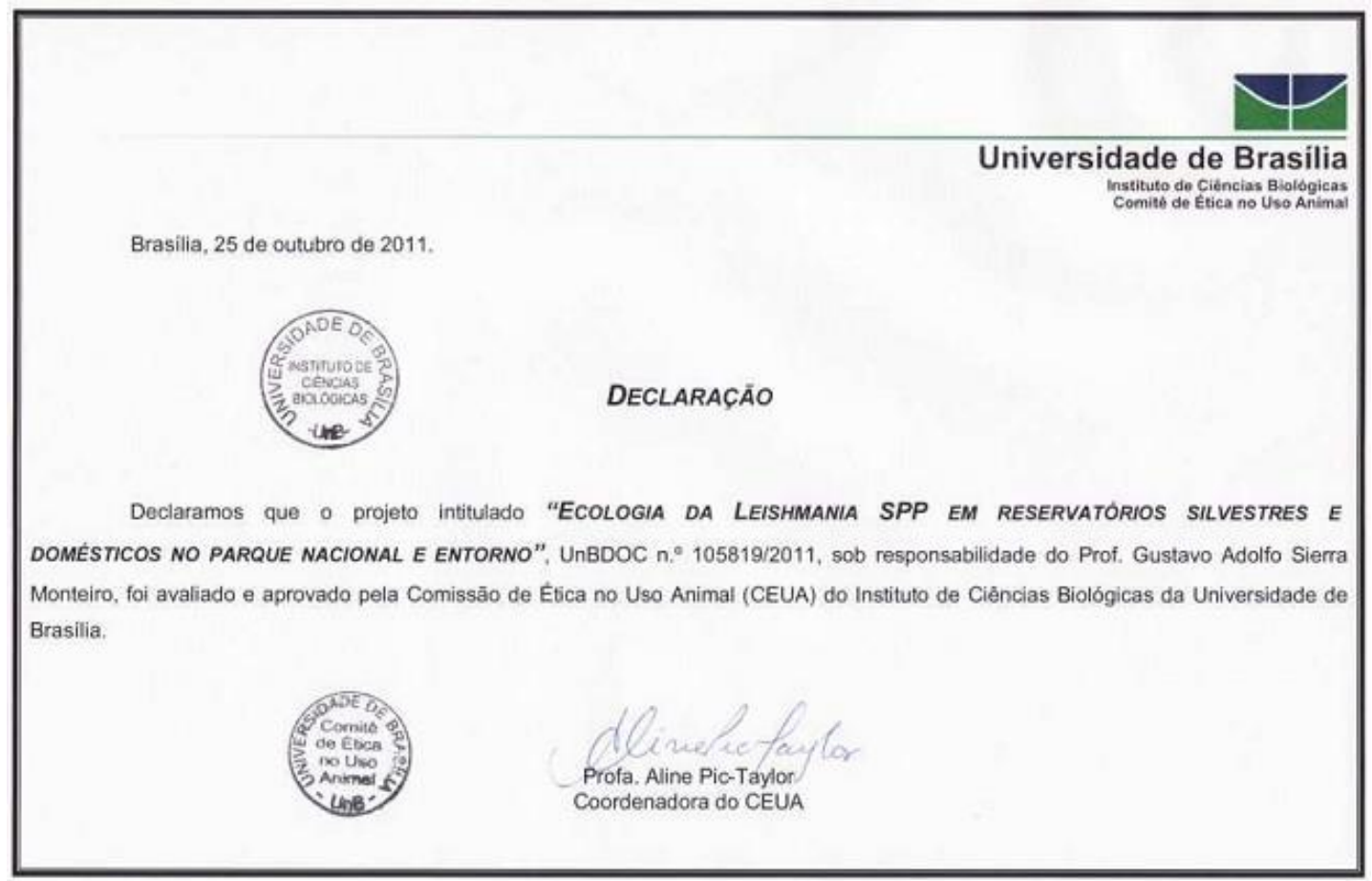




\section{ANEXO 2}

Ministério do Meio Ambiente - MMA

Instituto Chico Mendes de Conservação da Biodiversidade - ICMBio

Sistema de Autorização e Informação em Biodiversidade - SISBIO

Autorização para atividades com finalidade científica

\begin{tabular}{|l|l|l|}
\hline \multicolumn{1}{|c|}{ Número: 29486-4 } & \multicolumn{2}{|c|}{ Data da Emissão: 07/02/2012 09:30 } \\
\hline Dados do titular & CPF: $584.366 .933-53$ \\
\hline Nome: Rebecca Martins Cardoso & CNPJ: 00.038.174/0001-43 \\
\hline Título do Projeto: Eco-epidemiologia de tripanosomatideos em unidades de conservação e entorno no Distrito Federal. \\
\hline Nome da Instituição : FUNDAÇÃO UNIVERSIDADE DE BRASíLIA & \\
\hline
\end{tabular}

Cronograma de atividades

\begin{tabular}{|l|l|l|l|}
\hline$\#$ & \multicolumn{1}{|c|}{ Descrição da atividade } & Início (mês/ano) & Fim (mês/ano) \\
\hline 1 & Captura de pequenos mamiferos, coleta e análise do material biológico & $10 / 2011$ & $12 / 2012$ \\
\hline $\begin{array}{l}\text { De acordo como o art. 33 da IN 154/2009, esta autorizaçăo tem prazo de validade equivalente ao previsto no cronograma de atividades do projeto, mas deverá ser } \\
\text { revalidada anualmente mediante a apresentação do relatório de atividades a ser enviado por meio do Sisbio no prazo de até 30 dias a contar da data do aniversário de sua } \\
\text { emissão. }\end{array}$ \\
\hline
\end{tabular}
emissão.

Observações e ressalvas

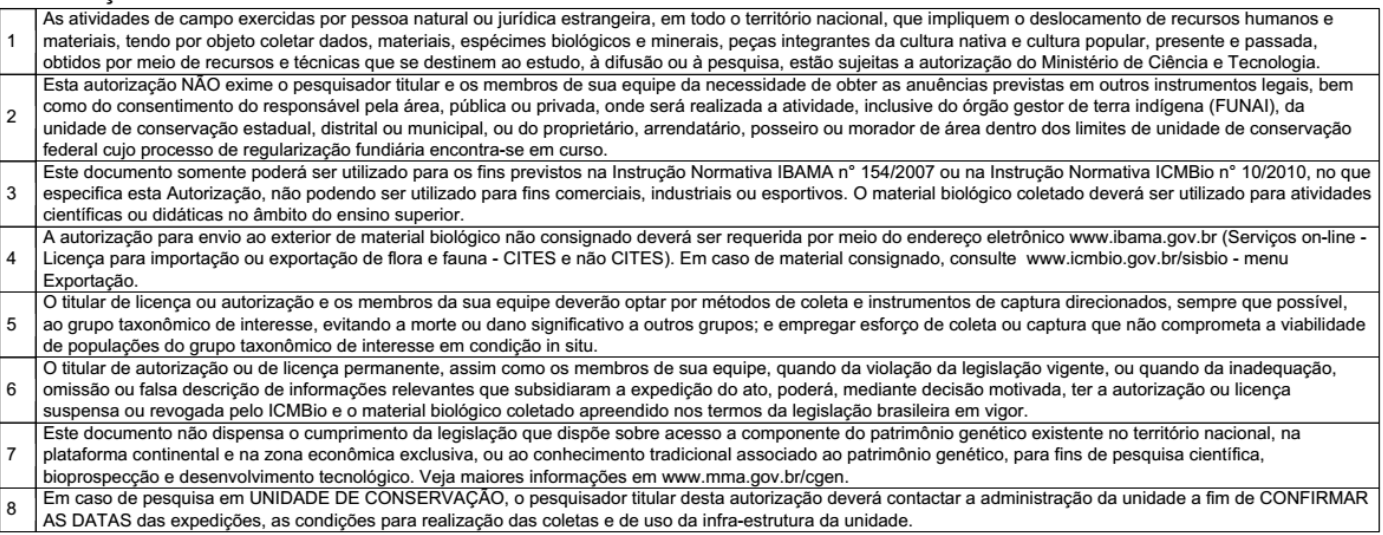

Outras ressalvas

\begin{tabular}{|l|l|l|}
\hline 1 & -NAO ESTA PERMITIDA A ABLACCAO DE DIGITOS PARA RODENTIA, DIDELPHIMORPHIA E DASYPODIDAE NA REBIO CONTAGEM/DF. \\
\hline
\end{tabular}

Equipe

Equipe
\begin{tabular}{|l|l|l|l|l|l|}
\hline$\#$ & \multicolumn{1}{|c|}{ Função } & CPF & Doc. Identidade & Nacionalidade \\
\hline 1 & David Duarte França & Colaborador & $017.899 .941-52$ & 2336940 ssp-DF & Brasileira \\
\hline 2 & Maria Jose de Oliveira Nunes & Estagiária & $717.323 .221-04$ & 1927272 SSP-DF & Brasileira \\
\hline 3 & Silvia Neri Godoy & Colaboradora & $256.929 .168-43$ & 177119007 SSP-SP & Brasileira \\
\hline 4 & rafael veríssimo monteiro & Colaborador & $000.252 .947-50$ & $06479910-9$ SSP-RJ & Brasileira \\
\hline 5 & Marina Motta de Carvalho & Colaboradora & $717.896 .501-00$ & 2131534 SSP-DF & Brasileira \\
\hline 6 & Nárjara Veras Grosmann & Colaboradora & $007.260 .661-41$ & 2181140 SSP-DF & Brasileira \\
\hline 7 & Juliana Bragança Campos & Colaboradora & $715.304 .361-68$ & 1974125 SSP-DF & Brasileira \\
\hline 8 & Fernanda Mara Aragão Macedo Pereira & Estagiária & $010.524 .471-63$ & 2485421 SSP-DF & Brasileira \\
\hline 9 & Rodrigo Gurgel Gonçalves & Co-orientador & $864.037 .531-34$ & 1749898 SSP-DF & Brasileira \\
\hline 1 & Pedro de Aguiar Botelho & Estagiário & $020.812 .501-95$ & - & B \\
0 & & & & Brasileira \\
\hline
\end{tabular}

Este documento (Autorização para atividades com finalidade científica) foi expedido com base na Instrução Normativa $n^{\circ} 154 / 2007$. Através do código de autenticação abaixo, qualquer cidadão poderá verificar a autenticidade ou regularidade deste documento, por meio da página do Sisbio/lCMBio na Internet (www.icmbio.gov.br/sisbio).

Código de autenticação: 47362418

Página 1/3 
Ministério do Meio Ambiente - MMA

Instituto Chico Mendes de Conservação da Biodiversidade - ICMBio

Sistema de Autorização e Informação em Biodiversidade - SISBIO

\section{Autorização para atividades com finalidade científica}

\begin{tabular}{|c|c|}
\hline Número: $29486-4$ & Data da Emissão: 07/02/2012 09:30 \\
\hline \multicolumn{2}{|l|}{ Dados do titular } \\
\hline Nome: Rebecca Martins Cardoso & CPF: $584.366 .933-53$ \\
\hline \multicolumn{2}{|c|}{ Título do Projeto: Eco-epidemiologia de tripanosomatideos em unidades de conservação e entorno no Distrito Federal. } \\
\hline Nome da Instituição : FUNDAÇÃO UNIVERSIDADE DE BRASÍLIA & CNPJ: $00.038 .174 / 0001-43$ \\
\hline
\end{tabular}

\begin{tabular}{|l|l|l|l|l|l|}
\hline 1 & JONATAS BARBOSA CAVALCANTE FERREIRA & Colaborador & $714.867 .201-53$ & 2087016 SSP-DF & Brasileira \\
\hline 1 & MARCELO LIMA REIS & Colaborador & $379.767 .611-53$ & 587335 SSP-DF & Brasileira \\
\hline $\begin{array}{l}1 \\
3\end{array}$ & Filipe Carneiro Reis & Colaborador & $003.471 .171-63$ & 2567590 SSP-DF & Brasileira \\
\hline $\begin{array}{l}1 \\
4\end{array}$ & CARLOS ABS DA CRUZ BIANCHI & Colaborador & $610.173 .611-34$ & 1391547 SSP-DF & Brasileira \\
\hline $\begin{array}{l}1 \\
5\end{array}$ & Gustavo Adolfo Sierra Romero & Orientador & $698.324 .981-04$ & - & Brasileira \\
\hline
\end{tabular}

Locais onde as atividades de campo serão executadas

\begin{tabular}{|l|l|l|l|l|}
\hline$\#$ & \multicolumn{1}{|c|}{ Municipio } & UF & Descrição do local & Tipo \\
\hline 1 & BRASILIA & DF & PARQUE NACIONAL DE BRASILIA & UC Federal \\
\hline 2 & BRASILIA & DF & RESERVA BIOLOGICA DA CONTAGEM & UC Federal \\
\hline
\end{tabular}

Atividades $X$ Táxons

\begin{tabular}{|c|c|c|}
\hline \# & Atividade & Táxons \\
\hline 1 & Captura de animais silvestres in situ & $\begin{array}{l}\text { Leopardus, Canidae, Mustelidae, Puma yaguarondi, Procyonidae, Rodentia, Didelphimorphia, } \\
\text { Dasypodidae }\end{array}$ \\
\hline 2 & Coleta/transporte de amostras biológicas in situ & $\begin{array}{l}\text { Puma yaguarondi, Mustelidae, Procyonidae, Leopardus, Rodentia, Didelphimorphia, Canidae, } \\
\text { Dasypodidae }\end{array}$ \\
\hline 3 & Coleta/transporte de espécimes da fauna silvestre in situ & Rodentia ("*Qtde: 4), Didelphimorphia (*Qtde: 4) \\
\hline 4 & Marcação de animais silvestres in situ & $\begin{array}{l}\text { Canidae, Mustelidae, Leopardus, Procyonidae, Didelphimorphia, Dasypodidae, Rodentia, Puma } \\
\text { yaguarondi }\end{array}$ \\
\hline
\end{tabular}

* Qtde. de individuos por espécie/localidade/unidade de conservação, a serem coletados durante um ano.

Material e métodos

2 Amostras biológicas (Outros mamiferos) $\quad$ Fezes, Sangue, Ectoparasita, Fragmento de tecido/órgão, Animal encontrado morto ou partes

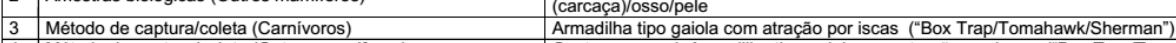

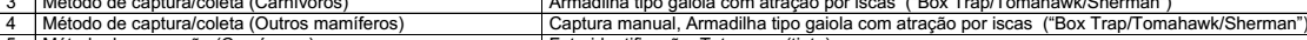

\begin{tabular}{l|l|l}
\hline 5 & Método de marcação (Carnivoros) & Foto-identificação, Tatuagem (tinta) \\
\hline 6 & Método de marcação (Outros mamiferos) & Brinco, Outros métodos de marcaçăo(ablacao de digitos), Tatuagem (tinta) \\
\hline
\end{tabular}

Destino do material biológico coletado

\begin{tabular}{|c|c|c|}
\hline$\#$ & Nome local destino & Tipo Destino \\
\hline 1 & FUNDAÇÃO UNIVERSIDADE DE BRASILIAA & \\
\hline
\end{tabular}

Este documento (Autorização para atividades com finalidade cientifica) foi expedido com base na Instrução Normativa n¹54/2007. Através do código de autenticação abaixo, qualquer cidadão poderá verificar a autenticidade ou regularidade deste documento, por meio da página do Sisbio/ICMBio na Internet (www.icmbio.gov.br/sisbio).

Código de autenticação: 47362418 
Ministério do Meio Ambiente - MMA

Instituto Chico Mendes de Conservação da Biodiversidade - ICMBio

Sistema de Autorização e Informação em Biodiversidade - SISBIO

Autorização para atividades com finalidade científica

\begin{tabular}{|c|c|}
\hline Número: $29486-4$ & Data da Emissão: 07/02/2012 09:30 \\
\hline \multicolumn{2}{|l|}{ Dados do titular } \\
\hline Nome: Rebecca Martins Cardoso & CPF: $584.366 .933-53$ \\
\hline \multicolumn{2}{|c|}{ Título do Projeto: Eco-epidemiologia de tripanosomatideos em unidades de conservação e entorno no Distrito Federal. } \\
\hline Nome da Instituição : FUNDAÇÃO UNIVERSIDADE DE BRASÍLIA & CNPJ: 00.038.174/0001-43 \\
\hline
\end{tabular}

\section{Registro de coleta imprevista de material biológico}

De acordo com a Instrução Normativa n¹54/2007, a coleta imprevista de material biológico ou de substrato não contemplado na autorização ou na licença permanente deverá ser anotada na mesma, em campo específico, por ocasião da coleta, devendo esta coleta imprevista ser comunicada por meio do relatório de atividades. O transporte do material biológico ou do substrato deverá ser acompanhado da autorização ou da licença permanente com a devida anotação. O material biológico coletado de forma imprevista, deverá ser destinado à instituição científica e, depositado, preferencialmente, em coleção biológica científica registrada no Cadastro Nacional de Coleções Biológicas (CCBIO).

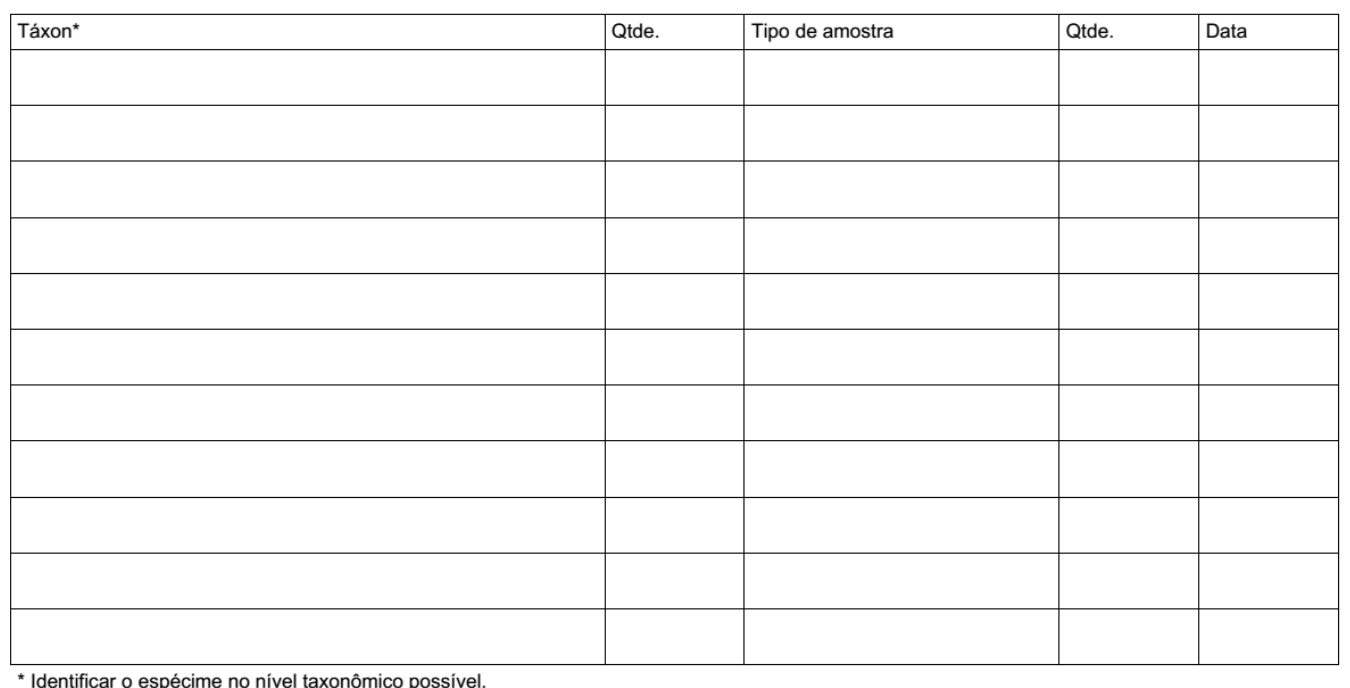

Este documento (Autorização para atividades com finalidade cientifica) foi expedido com base na Instrução Normativa n¹54/2007. Através do código de autenticação abaixo, qualquer cidadão poderá verificar a autenticidade ou regularidade deste documento, por meio da página do Sisbio/ICMBio na Internet (www.icmbio.gov.br/sisbio).

Código de autenticação: $\mathbf{4 7 3 6 2 4 1 8}$ 